\title{
Moderne sociale zekerheid: efficiency met behoud van fundamentele waarden
}

Citation for published version (APA):

Klosse, S. (2003). Moderne sociale zekerheid: efficiency met behoud van fundamentele waarden. Sdu Uitgevers. https://doi.org/10.26481/spe.20030101sk

Document status and date:

Published: 01/01/2003

DOI:

10.26481/spe.20030101sk

Document Version:

Publisher's PDF, also known as Version of record

\section{Please check the document version of this publication:}

- A submitted manuscript is the version of the article upon submission and before peer-review. There can be important differences between the submitted version and the official published version of record.

People interested in the research are advised to contact the author for the final version of the publication, or visit the DOI to the publisher's website.

- The final author version and the galley proof are versions of the publication after peer review.

- The final published version features the final layout of the paper including the volume, issue and page numbers.

Link to publication

\footnotetext{
General rights rights.

- You may freely distribute the URL identifying the publication in the public portal. please follow below link for the End User Agreement:

www.umlib.nl/taverne-license

Take down policy

If you believe that this document breaches copyright please contact us at:

repository@maastrichtuniversity.nl

providing details and we will investigate your claim.
}

Copyright and moral rights for the publications made accessible in the public portal are retained by the authors and/or other copyright owners and it is a condition of accessing publications that users recognise and abide by the legal requirements associated with these

- Users may download and print one copy of any publication from the public portal for the purpose of private study or research.

- You may not further distribute the material or use it for any profit-making activity or commercial gain

If the publication is distributed under the terms of Article $25 \mathrm{fa}$ of the Dutch Copyright Act, indicated by the "Taverne" license above, 
Moderne sociale zekerheid:

efficiency met behoud van fundamentele waarden 
Meer informatie over deze en andere uitgaven kunt u verkrijgen bij

Servicecentrum Uitgevers

Postbus 20014

2500 EA Den Haag

tel:: $070-3789880$

fax: $070-3789783$

\section{2003 Sdu Uitgevers BV, Den Haag}

Omslagontwerp: Villa Y, Den Haag

\section{ISBN 9054093366}

NUR 823

Alle rechten voorbehouden.

Behoudens de door de Auteurswet 1912 gestelde uitzonderingen, mag niets uit deze uitgave worden verveelwoudigd (waaronder begrepen het opslaan in een geautomatiseerd gegevensbestand) en/of openbaar gemaakt door middel van druk, fotokopie, microfilm of op welke andere wijze dan ook, zonder voorafgande schriftelijke toestemming van de uitgever.

De bij toepassing van art. $16 \mathrm{~b}$ en 17 Auteurswet 1912 wettelijk verschuldigde vergoedingen wegens fotokopiëren, dienen te worden voldaan aan de Stichting Reprorecht, Postbus 3060, $2130 \mathrm{~KB}$ Hoofddorp, tel. 023-799781.0.

Voor het overnemen van een gedeelte van deze uitgave in bloemlezingen, readers en andere compilatiewerken op grond van art. 16 Auteurswet 1912 dient men zich te wenden tot de stichting PRO, Postbus $3060,2130 \mathrm{~KB}$ Hoofddorp, tel. 023-7997809. Voor het overnemen wan een gedeelte van deze uigave ten behoove van commerciele doeleinden dient men zich te wenden tot de uitgever.

Hoewol an do lotstandkoming van deze witgave de uiterste zorg is besteed, kan woor de afwezigheid van eventuele (druk)fouten en onvolledigheden niet worden ingestaan en aravarden de auteur(s), redacteur(en) en uitgever deswege geen aansprakelijkheid woor de gewolgen wan eventueel voorkomende fouten en onvolledigheden.

All rights reserved. No part of this publication may be reproduced, stored in a retrieval system, or transmitted in any form or by any means, electronic, mechanical, photocopying, recording or otherwise, without prior written permission from the publisher.

While every effort has been made to ensture the reliability of the information presented in this publication, Sdu Uitgevers neither guarantees the accuracy of the data contained herein nor accepts responsibility for errors or omissions or their consequences. 


\section{Inhoud}

1. Socialle zekerheid en haar dilemma's

2. Hervormingsfilosofie 3

3. Is de hervormingsfilosofie juridisch houdbaar? 6

4. Juridisch kader 7

4.1 Zorgplicht voor het waarborgen van bestaanszekerheid 7

4.2 Ruime beleidsvrijheid 9

4.2.1 Primaat bij de wetgever 9 4.2.2 Betekenis woor de wetgeving op het terrein van
sociale zekerheid.

5. Consequenties voor de kwaliteit van de modemiseringswetgeving $\quad 12$

5.1 Financieel-economische belangen overheersen $\quad 12$

5.2. Wetgeving met een dubbele bodem 13

5.3 Vasthouden aan de ingezette koers 15

5.4 Positieve financiele prikkels als tegenwicht 16

5.4.1 Doeltreffend medicijn? 16

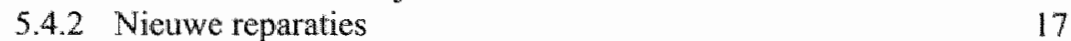

$\begin{array}{lll}5.5 & \text { Regulering van de aanstellingskeuring } & 18\end{array}$

$\begin{array}{ll}5.6 & \text { Voorllopig sluitstuk } \\ & 20\end{array}$

5.6.l Beperking van de toegang tot de WAO 20

$\begin{array}{ll}5.6 .2 \text { Flankerende maatregelen } & 21\end{array}$

5.7 Onduidelijkheid over controle en reintegratieverplichtingen $\quad 24$

5.7.1 Reikwijdte van de informatieplicht 24

5.7.2 Reikwijdte van de medewerkingsplicht 25

$\begin{array}{lll}5.8 & \text { Botsende grondrechten } & 26\end{array}$

5.8.1 Het recht op privacy wersus het recht op een eerlijke
procesgang

5.8.2 De medische besluitenregeling 27

5.8.3 Toereikende oplossing? 28

6. Recht zonder ruggengraat?

6.1 Rol van de kwaliteitseisen voor wetgeving 30

6.2 Rol van het juridisch kader 31

7. Ontwikkeling op Europees terrein 32

7.1 Sturing via een proces van 'open" coördinatie 32

7.2 Afstemming op bet economisch en monetair beleid 34

7.3 Doeltreffende aanpak? 35

7.4 Bijstelling van de koers 36

7.5 Houvast voor verbetering van de rechtsvorming? 
8. Rol van socialle grondrechten bij de modemisering van sociale zekerheid 39

8.1 Overheidstakk in de sfeer van sociale zekerheid 39

8.2 Concretisering van de uitgangspunten van sociale rechtvaardigheid aan de hand van een grondrechtelijk kader

8.2.1 Belang van een grondrechtelijke benadering 41

8.2.2 Betekenis van een grondrechtelijke benadering voor het werkgelegenheidsbeleid

9. Tijd voor de volgende stap 46

9.1 Half werk. 46

9.2 Nadruk op rechtsgelijkheid 46

9.3 Oog voor gelijke kansen? 49

10. Bijstelling wan de koers 51

10.1 Verandering van perspectief 51

10.2 Betekenis voor de WAO-plannen $\quad 52$

10.3 Slotsom 54 


\section{Moderne sociale zekerheid: efficiency met behoud van fundamentele waarden}

\section{Sociale zekerheid en harar dillemma"s}

"... De economische en budgettare siruare wan ons land is dramorisch slecher geworden. Het nienwe kabinet wil daarom hard aan de shag woor een beter Nederlond. Ondanks economische tegenwind moet er flinh vooruitgang worden geboek in het oplossen wan problemen waurnee de samenleving kampt...

Zo luidt het hoopvolle begin van het regeerakkoord dat op 16 mei 2003 werd gepre senteerd." Toch ontlokte dit akkoord meteen de nodige protesten. Verbazingwekkend is dat niet. De beoogde vooruitgang wordt namelijk met een forse begrotingsdiscipline gecombineerd. De weg naar een beter Nederland is hierdoor bezaaid met financiele voetangels en klemmen die samen een bezuiniging van rum dertien miljard euro moeten opleveren." lngrepen in de sociale zekerheid zijn onderdeel van dit bezuinigingspakket. Behalve op de al eerder aangekondigde hervorming van de WAO en de ziektekostenregelingen, ${ }^{3}$ hebben deze ingrepen onder meer betrekking op beperking van de uitkeringsrechten bij werkloosheid ${ }^{4}$ en een drastische herziening van de bijstandsregeling. ${ }^{5}$ De protesten richtten zich

1 Hoofdinnenakkoord voor het kabimet CDA, VVD en D66, 16 mei $2003, \mathrm{p} .1$

2 Dit blijki nit p. 16 en 17 van de bijlage bij het hoofdignenakkoond watrin het linancieel kadet $2004-2007$ word gescheist.

3 De lherworming van de ziektekostenregelingen komt kort gezegd neer op beperking wan het verzekeringspakket, werhoging van de angen bijdragen en verhoging van de doelnatigheid waurbij de sector een zware verantwoordelijkheid kri.gt (Hoofdlijnenakkoord, p. 7 en 8). De herziening van de WAO komt in grote lijnen neer op beperking van de toegang tot degenen die duwrzam volledig arbeidsongeschikt zijn onder gelikkijdige afschaffing van de gedeeltelijke WAO uttkeringen. Voor gedeeltelijk arbeidsgeschikten word" loon thet primaire altenatief. Lukt het niet on te werken, dan ligt overgang nar de werkloosheidsregelingen in lhet wersenget. Zie hierover nader par, $5,6.1$.

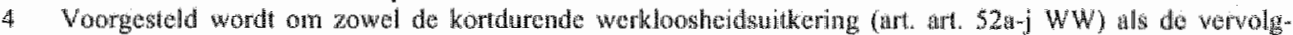

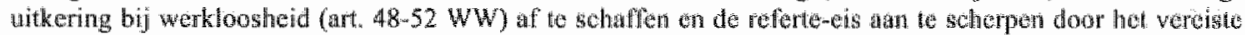

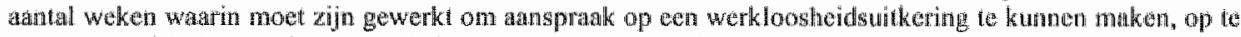
trekken van 26 uit 39 weken (art. 17 a WW) nar 39 uit 52 weken. Hoofdlighenakkoord, p. 17.

5 Zie darvoon het wetswoorstel Wet werk en bijstand (Wwb), TK 2002-2003, 28 870 an het Hoofditheth akkoord, p. 17. Doel van de hiorin verwate herzionith is bijgtandsgerechigden meer dan voorlheen te

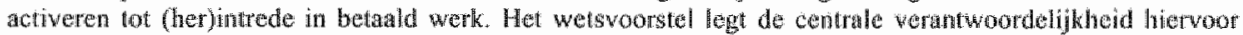
rolledig bij de gemeenten. Via een $100 \%$ wrj te besteden budgettering van de uilgaven, wordi gemoenten

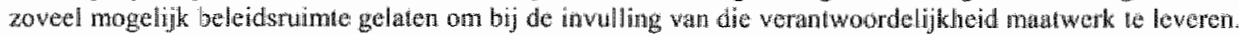
Actief beledd word zo beloond. Alle bijstandsgerechtigden jonger dan 65 jatr wotden gevinulect hiovian actue mea te werken door de hoogte van de witkering le koppelen an het betoonde verantwoordelijl. heddsbesef om te doen wat nodig is on zelf in het bestan te voorzich. Dit houdt onder meer in dall alle algemeen geacepterde arbeid moet worden geacepterend. Fen inkomenswarborg komt pas and do orde als mensen in stat bliken te zijn dergelijke arbeid in al dan tijdelijk gesubsidieerde vorm te werkrijgon.

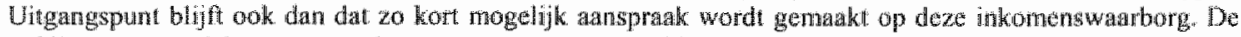

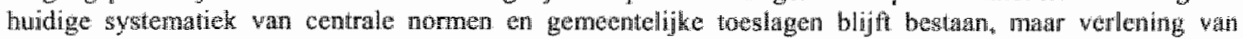
bijzondere bijstand gaat geschieden op basis van maatwerk. Verder voordiat het wetsvoorst in wan lang. dhugheidstoeslag voor mensen die geen perspectef hebben op tengkeer in het arbeidsproces. Het beat terzake wordt vastgelegd in en werdeming. Zie voor meer details TK 2002-2003, 28870, 19: $1-2$ en 3. 
echter mief primair op deze ingrepen. Zij spitsten zich toe op het voomemen om bestaande WAO-ers jonger dan 45 jaar onder het voorgenomen nieuwe WAO-regime te brengen. ${ }^{6}$ op zich is ook dat niet zo gek. Arbeidsongeschikten zijn immers al sinds het ende van de jaren tachtig het doelwit wan voortdurende wijzigingen in de sociale zekerheid. Belanghebbenden ervaren de voorgestelde matregelen als een verdere aantasting van hun bestaanszekerheid en vinden bovendicn dat er ten onrechte aan verworven rechten wordt getornd. "We laten ons niet verder witkleden" is dan ook hun devies. Het tegenargument, dat dit zo "n vaart niet zal lopen omdat het niewwe WAO-regime in ieder geval een deel van de doelgroep wan het gtempel "arbeidsongeschikt" zal bevrijden en daardoor hun kans op werk zal vergroten, heef in dit verband weinig overtuigingskracht. Over het algemeen hebben eerder genomen maatregelen on deelname aan het arbeidsproces te bevorderen immers niet tot meer werkzekerheid geleid. De woorgenomen ingrepen bevaten geen enkele garantie dat dit zal veranderen. Kenneljk zijn politici daar ook niet zo zeker van. Naar aanleiding van alle commotie over het hoofdijnenakkoord werd namelijk meteen al wat gas teruggenomen en een "financiel ordentelijke" uitwerking van de voorgestelde maatregel in het vooruitzicht gesteld. Betrokkenen wordt zo een doekje voor het bloeden aangereikt. De ingrepen zelf worden immers niet ter discussie gesteld, alleen de financiêle pijn wordt (vermoedelijk) wat verzacht.

Deze gang van zaken geft een aardige illustratie van een intrigerend dilemma in de sociale zekerheid. Zeker de laatste jaren is er een voortdurende spanning tussen de financieel-economische noodzaak om het stelsel wan sociale zekerheid te reorganiseren en de juridische noodzaak om daarbij recht te doen aan sociale zekerheden in de sfeer van werk en inkomen, die in intemationale verdragen en de Grondwet zijn verankerd. Die spanning vraagt om een gebalanceerde afweging tusisen financieel-economische en sociale waarden, die ieder voor zich essentieel zijn. Maar juist het vinden wan een balans tussen deze twee waarden blijkt in de praktijk op problemen te stuiten. Aan de ene kant zijn ingrepen in de sociale zekerheid noodzakelijk om de continuiteit daarvan te waarborgen. Tal van ontwikkelingen knagen namelijk atan het fundament van het publieke sociale zekerheidssysteem en zetten de houdbaarheid en betaalbaarheid daarvan onder druk. De combinatie van een slinkend antal jongeren en een groeiend antal ouderen veroorzaakt bijvoorbeeld problemen voor de Financiering van de ouderdomspensioenen. De ziektekosten rijzen de pan uit, maar blijken moeilijk beheersbaar. Het toenemend aantal dames op de arbeidsmarkt vraagt om creatieve alternatieven voor vormen van zorg die zij traditioneel op zich namen, zoals de zorg voor kinderen; ouderen zon zieke familieleden of vrienden.En verder blijf, ondanks een actief arbeidsmarktbeleid, een relatief. groot deel van de beroepsgeschikte bevolking afhankelijk van eer arbeidsongeschiktheids-, een werkloosheids- of een bijstandsuitkering. ${ }^{7}$ Al deze ontwikkelingen maken hervorming van het traditionele sociale zekerheidssysteem urgent.

62 2ie datswoor de bijlgge bij het Hoofdijnenakkoond, p. 17.

7 Un Eumopes verband wordt dit angenerkt als een structureel probleem en is Nederland herhaaldelijk anngesproken danwoor unatregelen te treffen. 2 ie bijv. Aanbeviling van de Raad van 19 januari 2004, Doc. ni. $32001 \times 0064$. 1. 17 an Mededelingen van da Commissie an de Raad in het kader van het gexamenlijk owerleg ower de werkgelegenheid 2002. Con (2002) 621 final, p. 89. Het wetswoorstel voor de nieuwe bijstandsrogeling tadakt hierop in: TK, $2002-2003,28870 \mathrm{~A}, \mathrm{p} .7$. 
Privatisering en bevordering van arbeidsparticipatie liken op het eerste gezicht doeltreffende middelen on deze problemen aan te pakken. Privatisering vernindert immers de collectieve lasten en versterkt tegelikertijd de individuele verantwoondelikheid om zelf door middel van arbeid of een particuliere verzekering in het bestaan te woorzien." Bevordering van arbeidsparticipatie draagt, op zijn beurt, bij aan de houdbaarheid en betaalbaarheid van het sociale zekerheidssysteem door verhoging van het aantal werkenden. Naar mate meer mensen werken ontstaat immers een breder draagvlak voot de findmciering van dat systeem. Alle potentiẻle arbeidskracht moet daarom worden ingezet, niet alleen die van uitkeringsontwangers, maar ook die van vrouwen en ouderen."

Op zich zijn dit logische gedachten. Toch stemmen de resultaten tot nu toe niet tot tevredenheid. Privatisering blijkt niet automatisch te leiden tot een efficiënter werkend systeem. Eerder werkt het een toenemende sociale ongelijkheid in de hand. Bovendien blijven bepaalde groepen moeilijkheden ondervinden bij het vinden of behouden wan work, on danks een heel scalla van maatregelen dat daarin verandering moet brengen. Het gevaar van sociale uitsluiting is hierdoor nog steeds reeel. De hamvraag is daarom hoe de modemisering van het stelsel van sociale zekerheid op een effectievere manier gestalte kan krijgen. Kan de continuiteit van het stelsel worden gewaarborgd zonder dat tegellikertijd allerlei sociale zekerheden in de sfeer van werk en inkomen in het gedrang komen? Op deze vraag is tot dusver geen bevredigend antwoord gevonden. Reden te meer om eens nat te gaan waar de schoen wringt en hoe eventuele knelpunten kunnen worden verholpen. On hiervan een beeld te krijgen, wordt eerst wat meer licht geworpen op de hervormingsfilosofie waarop de in gang gezette modernisering van de sociale zekerheid steunt. Vervolgens worden de knelpunten daarvan in beeld gebracht, gevolgd door mogelijke manieren om die weg te nemen.

\section{Hervormingsfilosofie}

Uitgangspunt van de filosofie die achter veel van de aangebrachte wijzigingen in het sociale zekerheidssysteem schuil gaat is dat de overheidstaak in de sfeer wan de sociale zekerheid een subsidiaire is. Burgers hebben primair een eigen verantwoordelijktheid om zell in het bestaan te voorzien. ${ }^{10}$ op de publieke sociale zekerheid kan daarom alleen cen beroep worden gedaan als dat echt nodig is. Als mensen door middel van arbeid voor zichzelf kunnen zorgen of als risico's tegen redelijke condities verzekerbaar zijn op de particuliere

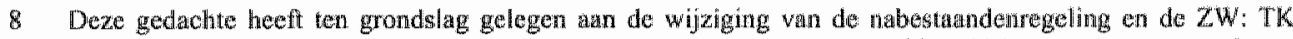
1994-1995, 24169, ar. 3, p. 1-7 en nr. 6, p. 2 an 13 (ANW) en TK. 1995-1996, 24 439, 11. 3, p. 2, c.v. (WUHBZ). Onder hetzelfde motto beperkte de TAA zowel de wogang tot de WAO als de hoogte en de dutar wan de WAO-unkering: TK 1002-1993,22,824, nur" 1-2 en nr. 5 en 6.

9 Zie voor deze gedachte bijw: Wetenschappelijke Raad voor het Regeringsbeleid, Eein Werkend Perspecter, Arbeidsparticipatie in de jaren negentig, Den Hag 1990.

10 Dit word gebaseerd op de in 1945 door de Commissie Van thijh geformuleerda rechtsgrond vowr soctale

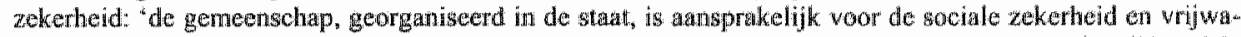
ring tegen yebrek van al har leden, op voonwarde dat deze leden zelf het redelijke doen orm zicli dic sociale

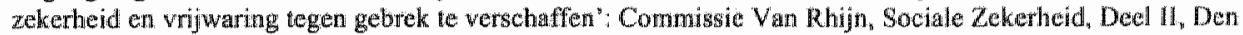
Hag A Agemeene Landsdrukkerij 1945, p. 10. 
verzekeringsmarkt dan wel binnen de arbeidsverhouding kunnen worden opgevangen, ligt overheidsinterventie met andere woorden niet langer woor de hand. ${ }^{n}$

De zorg voor sociale zekerheid verandert hierdoor van karakter. Nu de overheid op dit terrein in principe alleen een tak voor zichzelf ziet weggelegd als andere mechanismen tekortschieten, verschuift die zorg bijvoorbeeld woor een deel naar andere terreinen. Alternatieve beschermingstechnieken treden hierdoor op de voorgrond. Behalve voor de particuliere verzekeringen, geldt dit bijvoorbeeld ook voor thet arbeids(omstandigheden)recht, het aansprakelijkheidsrecht en het mededingingsrecht. De nadruk op de eigen verantwoordelijkheid om zelf in het bestaan te voorzien, heeft verder tot gevolg dat arbeid de primaire bron van bestaanszekerheid wordt. Ook dit geeft de zorg woor sociale zekerheid een ander accent. Daar waar vóór de reorganisatieperiode het accent lag op waarborging van een zekere inkomensbescherming bij het intreden van bepaalde sociale risico's, ligt het accent nu primair op het bevorderen van economische zelfstandigheid. Behoud en het creëren van werkgelegenheid wordt daarmee een essentieel onderdeel van het sociale zekerheidsbeleid. Tegelijkertijd wordt hiermee benadrukt dat sociale zekerheid niet alleen een curatieve, inkomenswaarborgende functie heeft, maar voorall ook een preventieve, activerende functie en wel in die zin dat alle zeilen moeten worden bijgezet om te voorkomen dat mensen (langdurig) afhankelijk worden van inkomensvervangende uitkeringen. ${ }^{12}$ Het is primair aan het bedrijfsleven om hieraan invulling te geven. Dit kan op uiteenlopende manieren, bijvoorbeeld door te investeren in goede, gezondheidsbevorderende arbeidsomstandigheden en een actief en doeltreffend beleid om ziekteverzuim te voorkomen of in ieder geval te beperken in omvang en duur. ${ }^{13}$ (Private) arbo-diensten moeten hierbij de nodige ondersteuning verlenen. ${ }^{14}$ Hiernaast kunnen ook de inmiddels geprivatiseerde reïntegratiebedrijven werkgevers en werkzoekenden de nodige steun verlenen bij het realiseren van de doelstelling om (langdurige) uitkeringsafhankelijkheid waar mogelijk te vermijden. De manier warap zij dat doen wordt bewust overgelaten aan de heilzame werking van de markt. Dit, in de verwachting dat de uitwoerende instanties zo extra worden geprikkeld om doeltreffend

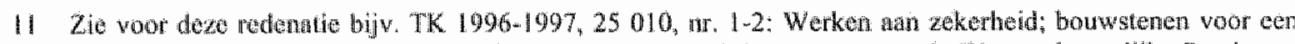
modem wondbar stolsel wan sociale zekerbeid. Zie ook We rapport van de Wetenschappelijke Raad voor het Regeringsheled: Van Verdelen nar Verdienen; afweghgen voor sociale zekerheid in de 21 eeuw, Den Hag SDU 1997; de Sociale Mola 1995 TK 1994-1995, 23 902, nr 1-2, p. 113 e.v. en de SER-studie, Vorntwoondelijkhoidswerdeling Sontal Zekerheid, Den Hage 1994, p. 43-80.

12 Lie hicwoor nuder onder meer: W. van Voorden. Prevente in de sociale zekerheid: mooi perspectief of on

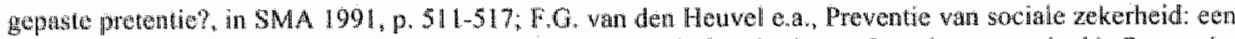
wenkond perspectiot, in SMA. 1991, p. 599.602 an in kritische zin J. van Stemberge e.an (red), Preventie: solide busis voor de soevale zkektheid, Antwerpen/Apeldoorn Maklu Uigevers, 1994, p. 15-102 en $287-299$.

13 Mew concret kam bij wen gewondheidsbevorderend beteid onder neer worden gedacht aan het zorgen voor evenwichtige werkdink, hett workonen wan burned-out syndromen en stressklachten, het verlenen van opfriswerloven en mogelijktheden om de loopban tjodeljk te onderbreken, hat bieden van camrière perspectieven

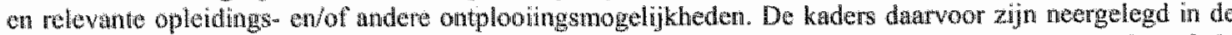
Arbeidsomstandighederwet, do Wet Arbeid en Zorg, de Wet Aanpassing arbeidsdum en, voor wat betreft de bestrijding van ziektevenzum, acentelyk nader ingevuld door de Wei Verbetering Poortwachter.

Dil is geregeld in ant. 14 Arbowet. 
en efficient te werk te gaan. ${ }^{15}$ De overlueid heeft zichzelf dus ook op dit gebied een sub sidiaire rol toebedeeld. ${ }^{\text {th }}$

De nadruk op de eigen verantwoordelijkheld om zelf in het bestaan to voorzien brengt verder mee dat van alle betrokkenen een maximale inspanning wordt verwacht om an het wark te blijwen of te komen. In dit kader worden werkzoekende uitkeringsgeredigden via sancties nadrukkelijk aangesproken op hun verantwoordelijkheid om iedere kans op werk aan te gripen. ${ }^{\text {th }}$ Damaast worden van werkgevers, werknemers en uitvoeringsinstanties zichtbare inspanningen verwacht om te voorkomen dat een (kangdurig) beroep op het uftkeringssysteem wordt gedaan. Doen zij dat niet, dan kan dat ook voor hen behoorlijke financiele consequenties hebben. ${ }^{18}$ Betrokkenen noeten zo eveneens worden geprikkeld tot een actieve opstelling in de sfeer van het aanbieden, aanvaarden of behouden van werk.

15 Zie dalrwoor bijw. de notitie Naar een werkende reintegratiemarkt; het onderzoekstapport Op weg naar volwassentheid": tweede inventarisatie wan de stand wan zaken op de markt woor neintegratiediensten van he: onderzoeksbureau Regioplan en de daarop woortbouwende nottie "Reintegratiebeleid": "W 2002-2003, 28 719, nir. 1, waarin nog eens wordt benedrukt dat de rembegatiemarki maximats ruime now krijgen en

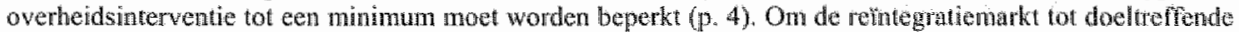
acties te prikkelen is volledige resultadfinanciering het titgangspunt. Daarnasas wordt gewerkt mat onderlinge vergelijking van resultaten wa "prestatie benchnarks" (p. 7-8). Scherp an zakelik onderhandelen mosen

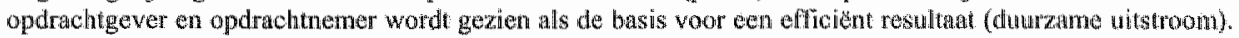
Markconforme prifsvoming moet tewens afroming voorkomen door de anbesteding, anders dan voorheen, te richten op kleine, moeilijk bemiddelbare groepen zodat inspamingen beter op hun behoeften kunnen worden gericht en de prijs darop kan worden fgestend (p. 13-16).

16 Her mededingingsrecht heeft heraan overigens ook een steenije bijgedragen. Hat furopese Hof van Justitte heef inmiddels uitgemalkt dat het niet toelaten van prvate bemiddelingstureau op do bemiddelingsmarkt in strijd is met art. 90 lid I en art. $86 \mathrm{EGW}$ als overheidsinstanties "klabblijkelujk niet in stat zijn om voor alle soorten activiteiten aan de vraag op de arbeidsmarkt te voldoen". De overheid kan zich dan niet het exclu* sieve wecht woobehouden om bemiddelingsactiviteiten tussen werkzoekender en werkgevers alleen door owerheidsinstanties te laten verrichten (Zic bijv. ECJ in de zak Hoffner and Elsner, Case C-41/90 (1991), ECR 1-1979; in de zak Job Centre Coop, Case C-55/96 (1997), ECR I-7119 en in de zak G. Carra, Case C258/98 (2000), ECR -4217). In het licht van deze jurisprudentie, en de beniddelingsnesullaten van de

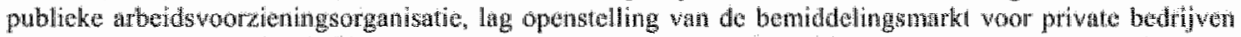

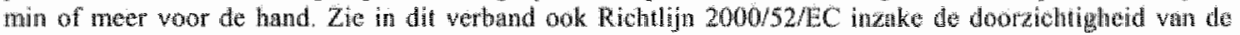
betrekkingen musen overheden en hun operbare bedrijwen an het Weswoorstal Marki en Owithed TTK 2001 -

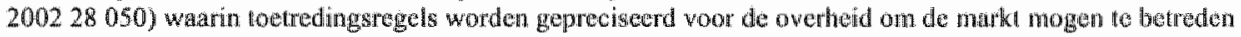
en gedragsregels wonden verankerd, 20 als het werbod op kruissubsididuing twsen publiohe en private activiteter en een verbod op bevoordeling van overheidsbedriven boven andere ondememingen wamce owerieidsbedrijen in concurentie treden. Hot loezich hierop ligt bij de NMA.

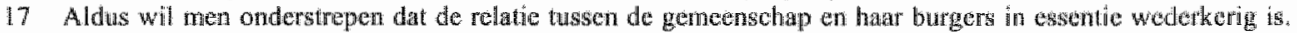
De solidarteit warop het stelisel var sociale zekerheid is gebaseerd, houd weliswar in dat de gemeengelap solidair is met de net-actieven, maar daaraan zijn wel grenzen. Van degenen die werkon kan geen blijvende

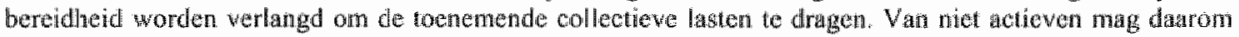
worden gevragd dat zil hum best doen om het beroep op sociale zekerheid zo hort mogelijk to houden. Het wets \-2 en 3). Zie woor eeth aerdere uitwerking van deze gedachte bijv: NotideVolumebele 1979 , "TK 1978/

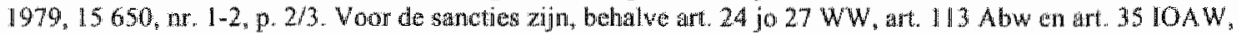

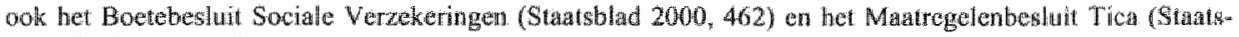
blad 1996,141 ) wan belang.

Is Zie woor deze beleidslijn nader bijw. Wetemschappelike Raad voor het Regeringsbeleid, Actiwerend Arbeids-

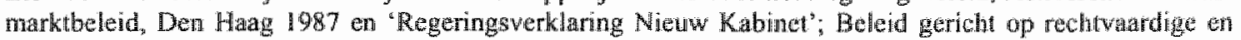

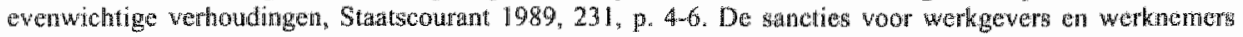




\section{Is de hervormingsfilosofie juridisch houdbaar?}

De ingezette koerswijziging op het terrein van de sociale zekerheid lijkt op het eerste gezicht een verantwoorde, bij de huidige tijd passende stap. Toch roept die ontwikkeling een aantal vragen op. Zo schuift de overheid de zorg voor sociale zekerheid hiermee in wezen af naar belanghebbenden zelf, c.q. naar het bedrijfleven en de private verzekeringsen reïntegratiemarkt. Maar in hoeverre heeft de overheid het recht dit te doen? Heeft de overheid niet ten minste de plicht ervoor te zorgen dat alternatieve beschermingssystemen belangliebbenden op een gelijkwaardige manier beschermen tegen bestaansonzekerheid als een publiek systeem zou doen? Juist als er wijzigingen in het geding zijn die de zorg voor sociale zekerheid woor een belangrijk deel overlaten aan 'de markt', lijkt het zaak hier extra op te letten. Gelijkwardige bescherming is dan immers geen gegeven. Daarvoor is namelijk onder meer vereist dat de uitgangspunten van sociale rechtvaardigheid waarop het publieke sociale zekerheidsstelsel steunt, op de één of andere manier in die alternatieve systemen worden geintegreerd. Maar dat is bepaald niet vanzelfsprekend. De aangedragen alternatieven steunen immers voor een belangrijk deel op eigen inspanningen en de werking wan de particuliere verzekeringsmarkt, terwijl het publieke systeem er juist op uit is de negatieve effecten daarvan te corrigeren om zo te voorkomen dat er tekorten in het beschermingsniveau gaan ontstaan. Solidariteit en ongelijkheidscompensatie nemen daarom in een publiek systeem een centrale plaats in. ${ }^{19} \mathrm{Zij}$ zijn de pijlers waarop dat systeem rust en, daarmee, cruciale middelen om de mens een veilig en menswaardig bestaan te bieden als de markt daarin tekortschiet en individuen of groepen buiten de beschermingsboot dreigen te vallen. Solidariteit en ongelijkheidscompensatie dragen zo bij aan maatschappelijke geborgenheid en, daarmee, aan de verwezenlijking van een gë̈ntegreerde maatschappij waarvan geen individuen of groepen zijn buitengesloten. In essentie schuilt hierin de kern van sociale zekerheid. ${ }^{20}$

Als alternatieve beschermingssystemen de functies van het publieke sociale zekerheidssysteem gaan overnemen, kunnen deze intrinsieke waarden van het publieke systeem gemakkelijk in het gedrang komen. Deze waarden zijn namelijk niet 'eigen' aan die alternatieve systenen en laten zich daarin ook niet automatisch integreren. Als gevolg hiervan kunnen tekorten in het beschermingsniveau gaan ontstaan, bijvoorbeeld doordat het solidariteitsgehalte afneemt en nuet iedereen in gelijke mate toegang heeft tot de alternatieve beschermingssystemen. Zo kunnen particuliere verzekeringen voor bepaalde groepen finan-

zilin bijw te vinden in art. 7:629 lid 11, c BW jo art. 7la lid 9 WAO resp. in art. 7. 629 lid 3, e, d en e BW, wrt. 7. 670b lid 3 BW an art. 25-28 WAO. Op de uiwoeringsorganissatie wordt met mame druk uitgeoefend wia een resultatsgerichie tinanciering wan de unigaven.

19 Zie bijw. M.O. Levenbach, Nederlands Bestuurstecht, deel II, afdeling I, Arbeid, Alphen aan de Rijn 1964, hoofdstuk I: G.J.M. Veldkamp, Inleiding tot de sociale zekerheid, Deventer Kluwer 1978, deel I: Karakter en Geschiedenis; W.J.H, van Oorschot, Solidariteit in verzekering en sociale zekerheid; analyse wan een begrip. SMA 1991, p. 461-471 en E.P. de لong, De verzekeringsgedacthe in de sociale zekerheid, in: Sociaal en Zeker, ll. A.J. van den Bosch (red.), Deventer Kluwer 1986, p. 65-79.

20 Zie hiervoor mader bijw. N.Z.H. Van Esweld, Sociale rechtsworning, Alphen a/d Rijo 1967, p. 1.1; J.J.M.Van der Ven, Sociale zekerheid als maatschąppelijk verschijnsal, SMA 1967, p. 154-155 en P.F. van der Heijden en F.M. Noordam, De waurde(n) van thet sociall recht; over beginselen van sociale rechtsvorming en bun werking, Devemter Tjeenk Willink, 2001 , p. 4 en 74. 
cieel onbereikbaar zijn of niet toegankelijk omdat verzekeraars bepaalde risico's niet tegen redelijke condities kunnen (of willen) verzekeren. Ook de toegang tot het arbeidsproces kan voor bepaalde groepen op moeilijkheden stuiten. De (start)positie op de arbeidsmarkt is nu eenmaal niet voor iedereen gelijk. Zonder nadere corrigerende maatregelen kan zo, in plats van maatschappelijke integratie, voor bepaalde groepen juist het gevaar van sociale uitsluiting gaan ontstaan.

Willen alternatieve beschermingssystemen een gelijkwaardig beschermingsniveau bieden, dan zal de wetgever dit soort tekorten in het beschermingsniveau met aanvullende mastregelen moeten compenseren. De vraag is echter of en zo ja in hoeverre de wetgever hiertoe kan worden verplicht. Bestaat er zolets als een plicht om te waarborgen dat de intrinsieke waarden van het publieke sociale zekerheidssysteem niet geheel en al wit het zicht verdwijnen als dat stelsel op een modernere leest wordt geschoeid? Deze vraag laat zich gemakkelijker stellen dan beantwoorden. Het juridisch kader waarmee do wetgever bij zo'n veranderingsproces rekening moet houden, zou daarbij houvast moeten bieden maar juist op dit terrein is onduidelijkheid troef. De afweging die in dat proces moer worden gemaakt tussen de financieel-economische noodzaak om de continuïteit van het stelsel van sociale zekerheid te waarborgen en de juridische noodzaak om daarbij recht te doen aan de sociale zekerheden die het juridisch kader biedt (zoals het recht van eenieder op gelijke kansen op maatschappelijke integratie en bescherming tegen sociale uitsluiting), valt als gevolg hiervan al snel uit ten faveure van het eerstgenoemde belang. Zoals hieronder zal blijken, heeft dit echter wel een prijs. Zo blijkt dit bijvoorbeeld gemakkelijk te kunnen leiden tot wetgeving die in allerlei opzichten te wensen overlaat en daardoor, in plaats van sociale zekerheid, eerder sociale ónzekerheid creëert.

Of en zo ja hoe hierin verbetering kan worden gebracht, is met het oog op deze uitkomst een belangrijke vraag. Verduidelijking van het juridische kader lijkt in dit kader een cruciale stap. Verduidelijking van het juridisch kader kan immers bevorderen dat de juridische randvoorwaarden en uitgangspunten explicieter in aanmerking worden genomen bij de afweging van sociale en economische belangen die in het kader van de modernisering van de sociale zekerheid een rol spelen. Het vinden van een balans tussen daarbij aan de orde zijnde economische en socialle waarden kan daardoor worden vergemakkelijkt. Op zijn beurt kan dit zowel de effectiviteit als de kwaliteit van de moderniseringswetgeving ten goede komen. Om te begrijpen welke factoren hieraan vooralsnog in de weg staan, zall daarvan nu eerst een beeld worden geschetst. Tegen deze achtergrond zal vervolgens worden nagegaan hoe kan worden bevorderd dat het juridisch kader zich in het wetgevingsproces nadrukkelijker kan laten gelden.

\section{Juridisch kader}

\subsection{Zorgplicht woor het waarborgen van bestaanszekerheid}

Het juridisch kader voor het overheidshandelen op het terrein van de sociale zekerheid wordt hoofdzakelijk gevormd door een aantal op dat fenomeen betrekking hebbende sociale grondrechten en daarmee samenhangende rechtsbeginselen, zoals het gelijkheidsbeginsel, 
het rechtszekerheidbeginsel en het evenredigheidbeginsel. Behalve in internationale verdragen, zijn de sociale grondrechten sinds 1983 ook in de Nederlandse grondwet verankerd. ${ }^{21}$ Dit, in de gedachte dat thet idearl van vrijheid en gelijkheid, zoals belichaamd in de klassieke grondrechten, een aamvilling nodig heeft om ten volle materiele betekenis te krijgen. Een Grondwet, geschreven voor nu en de toekomst, mag hieraan niet voorbij gaan en dient, naast de vastlegging wan de geestelijke en fysieke wrijheid en gelijkheid, ook aandach te besteden aan de bestaanszekerheid van de mens en het streven naar zijn individwele en maatschappelijke ontplooing."22

Tegen deze achtergrond roepen de sociale grondrechten de overheid op om in deze sferen activiteiten te ontplooien. ${ }^{23}$ In de grondwet is deze opdracht onder meer geexpliciteerd in de zorgplicht om de bestaanszekerheid van de burger te waarborgen. ${ }^{24}$ Dit is een brede opdracht, die meer omvat dan de, ook nader omschreven, taak om op het terrein van de sociale zekerheid regelend op te treden. ${ }^{25}$ Volgens de parlementaire stukken strekt de zorg voor bestaanszekerheid zich namelijk niet alleen uit tot het inkomen van degenen die niet door middel van arbeid in hun bestaan kunnen voorzien, maar ook tot het inkomen van de arbeidende mens. De zorg voor bestaanszekerheid omvat daarom bijvoorbeeld ook de bevordering van evenwichtige inkomensverhoudingen, het beleid tot vaststelling van minimumlonen, het algemene economisch beleid en het doen van overheidsuitgaven door het voeren van een bepaalde fiscale politiek of saneringsmaatregelen. ${ }^{26}$ Daarnaast bevatten de grondwettelijke zorgplichten voor voldoende werkgelegenheid, de bevordering van de volksgezondheid en het voeren van een actieve onderwijspolitiek eveneens aspecten die de zorg-

21 zie disarvor art. $19 \mathrm{t} / \mathrm{m} 23$ Grondwet. Voor wat betreft de intemationale werdmgen zijn onder meer van belang art. 1, 12, 15 en $31 \mathrm{ESH}$; 2, 2, 4, 6 en 9 WESCR; art. 8 en 14 EVRM; art.26 IVBPR; ILO-verdrag 44, 102, 121, 122 an 128 en de Europese Code inzake Sochale Zekeheid (1964). In 1990 is deze Code therzien, man nog geen enkel lid vain de Raad wan Europa heeft deze herziene Code bekrachigd. Nederland is op dit punt met name teruglyoudend wegens twijtel of de geprivatiserde $Z W$ en de PEMBA de toets van de hemane Code wel zullen kunuen doorstan. Ziv dwarvoor biju.: TK 1996-1997, 25 524, nr. 3, p. 2 en 1997-1998, Aanhangsel nir. 3097

22 Aldus edu tegringsnota ult 1974: TK $1973-1974,12944$, nr. 1, j3. 307/8. Wriheid en gelijkheid zijn beiden.

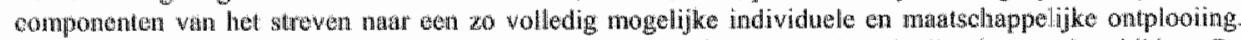
Op grond wa het getijkheidsbeginsel moet eenieder over de kans op zelfontplooing kunnen beschikken, De

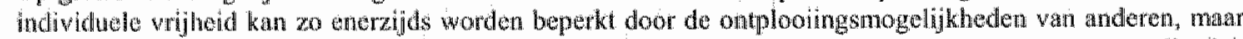
anderzijs kan gelike betiandeling ook en vootrwarde zijn voor induiduele wriheid. Voor groepen die zich in eev achterstandspostlic bevinden of door thet bestaan wan wooroordelen worden belemmerd in hun zelf-

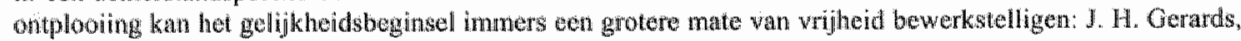
Rochterlijke toetsing an het gelijktheidsbeginget, Den Hadg SDU 2002, p. 1 .

23 De parlementaire stukken spreken in dit wetband ower ean fundamentele overluédstak. Zie bijv. TK 13873 , nr. 3, p. 6 an ar. 7, p. 1. Aan dwe takk kan op verschillende manieren uitwoering worden gegeven, bijv. door regels te stellen, ergens zorg voor te dragen, resultiat te berikent.

24. Att. 20 lid II Grondwet: de bestanszekrthoid der bevolking en spreiding van welvant zajn woorwerp van zorg van die owerheid.

25 Art 20 lid 2 Grondwet: de wet stett regels omtrent de anspraken op sociale zekerheid. Art. 20 lid 3 Grond-

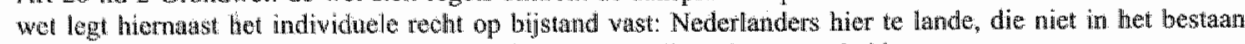
kunnen voontan, hebben een bij wet te regelen reche op bijstand van overheidswege. Zic: IK 1975-1976, 13873 , nn. 1-4, p. 12 en 1976-1977, nr. 7, p. 18. 
plicht voor bestaanszekerheid nader inkleuren. ${ }^{27}$ De zorgplicht voor bestaanszekerheid heeft hierdoor een overkoepelende functie; zij fungeert in wexen als brug tussen grondrechten die te maken hebben met arbeid aan de ene kant en met sociale zekerheidsuitkeringen aan de andere kant. ${ }^{28}$

\subsection{Rwime beleidswitheid}

\subsubsection{Primaat bij de wetgever}

De kwaliteitseisen voor wetgeving schrijven de wetgever voor om bij zijn wetgevende activiteiten steeds na te gan of deze wel stroken met (de strekking van) relevante grondrechten en de daarmee samenhangende beginselen. ${ }^{29}$ Dit betekent overigens niet dat eenmaal totstandgekomen wetgeving, die uitwoering geeft aan een bepalld grondrecht, niet voor verandering vatbaar zou zijn. Aanpassing van wetgeving aan nieuwe ontwikkelingen is wel degelijk mogelijk. Onduidelijk is echter hoe ver deze aanpassingen kunnen gaan. De bepalingen waarin de sociale grondrechten zijn verankerd laten dat bewust in het midden. Zij zijn geformuleerd als instructienormen en bevatten daarom wiet meer dan een opdracht aan de overheid of de wetgever om een bepaalde, wenselijk geachte situatie te (helpen) verwezenlijken. ${ }^{30} \mathrm{Bij}$ de uitvoering van deze opdracht mag rekening worden gehouden met de feitelijke mogelijkheden en relevante politieke en sociaal economische omstandigheden. ${ }^{31}$

Wetgevende en besturende organeñ wordt zo een ruime beleidsmarge gelaten. Zij hebben een grote mate van vrijheid om, in het licht van actuele politieke en sociaal economiscine omstandigheden, te bepalen hoe zij aan hun grondrechtelijke opdrachten uitvoering geven. Dit wordt nog eens versterkt doordat de rechter deze beleidsvrijheid moet respecteren en zich daarom bij de toetsing van de overheidsactiviteiten op dit terrein terughoudend moet opstellen. Voor zover die activiteiten als bestuurshandelingen kumen worden gekwalificeerd, brengt dit bijwoorbeeld mee dat de rechter zich zal moeten beperken tot een rechtmatigheidstoets en, daarmee, tot de vraag of bestuurshandelingen in overeenstemming zijn met de algemene beginselen van behoorlijk bestuur. In beginsel betekent dit dat er alleen numte is voor een rechterlijke toetsing als er sprake van willekeur en het bestutursorgan dus bij de afweging van de in aanmerking komende belangen in redelijkheid niwt had mogen handelen zoals het heeft gedaan. Door de aan bestuursorganen gegeven beleidsrumte zal daarvan echter niet gauw sprake zijn. Gaat het om wetgevende activiteiten, dain mag de

272 Le datrvoor art 19,22 en 23 Grondwet.

28 Zie darvoor nader bijw. P.F. wan der Hejden en F. M. Moordam, De warde(n) wan het socital recht; over beginselen van sochake rechtsvorming el hun werking, Deventer Jjeen Willak 2001 , p. 80.

29 Zie daarvoor de nota Zicht op Wetgewing. TK 1990-1991, 22 008, nr. 1-2, p. 24; de nota wetgewingshaliteit en Wetgevingevisitatie. TK $2000-2001,27475, \mathrm{mr}, 2, \mathrm{p} .14$ en de ndere uitwerking darwan in de Aanwijzingen woor de regelgewing, Gereedschap voor de wagevingspraktijk deel 4, Den Hag 200. Met name Aanwijzing 18 bepaalt cxplictat dat wetgeving in overenstemming moet zijn met hogene regels. wantonder

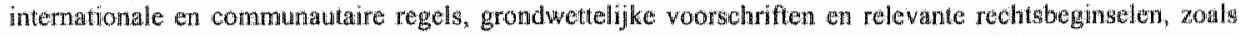
het gelikheidsbeginsel, het rechlszeketheidbeginsel en het evenredigheidsbegingel als bedoeld in art. 3.4 Awb. Ook in de MvT bij de herziene Grondwet wordi opgemerkt, dat de sociale grondrechten moeten dienen als uitgangspunt bij de gedachtewisseling in de Staten General: TK 1975-1976, 13,873, nr. 3, p. ?.

30 Zie bijv. TK 1976-1977, 13873, nr. 7, p. 2 en 12

31 Zie daaryoor bijw: TK 1975-1976, 13873, ar. 3, p. 6-8 an 1976-1977, 13 873, ni. 7, p. 6 an p. 12, 
rechter deze activiteiten, voor zover deze hun beslag krijgen in wetgeving in formele zin, nict toetsen alan de Grondwet. ${ }^{32}$ Toetsing aan relewante bepalingen in internationale verdragen is wel mogelijk, mits deze bepalingen kunnen worden aringemerkt als "eenieder verbindend" in de zin van art 93 Grondwet. Bepalingen die zijn geformuleerd als instructhenorm zijn daarvoor in het algemeen niet concreet gerioeg en lenen zich daarom niet direct voor een rechterlike toetsing. ${ }^{3}$ Het primaat van de beoordeling hoe sociale grondrechten zullen worden ingevuld ligt als gevolg hiervan bij de wetgever. ${ }^{34}$

\subsubsection{Betekenis voor de wetgeving op het terrein van sociale zekerheid}

Toegespitst op het terrein van de sociale zekerheid impliceert dit kader dat veel geoorloofd is zolang de warborgen die ten tijde van de grondswetswijziging in 1983 bestonden maar net helemaal worden ingetrokken en de minimum waarborgen, vastgelegd in intemationale verdragen waraan Nederland zich heeft gecommitteerd, maar worden gerespecteerd. ${ }^{35}$ Bij wijzigingen in de sfeer van de sociale zekerheid wordt in het algemeen getoetst of aan deze woorwaarden wordt woldaan. ${ }^{36}$ Meestall levert deze toetsing echter geen noemenswaardige

32 Art 120 Grondwet belet dat.

33 Zie bijw. CRwB 10 april 1991, AOW 1990/68, RSV 1992, 316. Zie voor een uitzondering op deze regel bijy. CRvB 26 mei 1996, RSV 1998, 9. Hierin werd een regeling op grond wakrwan een eigen bijdrage moest worden betald woor bevalling in ten ziekenhuis getoets aan de normen neergellegd in ILO-verdrag 102 en 103. Dit werd nogelijk geacht ondat de norm. watre het in deze procedure omging, natar het oordeel van de CRVB, mede door de imperatieve rodactie van het minimumkarakter van deze verdragen in het algemeen als wan de desbetreffende bepaling in het bijzonder, voldoende nauwkeurig was omschreven en zich daardoor wel woor rechterlijke toetsing leende. Zie ook CRvB 14 manar 2003, USV 2003/6, m. nt M. Driessen, p. 410. 419. Ook daarin werd aan een bepaling ILO-verdrag 118 (art. 5 lid 1) rechtstreekse werking toegekend. Doorslaggevend was hier dat deze bepaling verdragsluitende partijen een nauwkeurige en onvoorwaardelike verplichting oplegt, ter uitvoering walarvan geen nadere overeenkomsten moeten worden gesloten

34 In de MvT bij de herziening van de Grondwet in 1983 wordt in dit verband benadrukt dat er wegens gebrek aan heldere toetsingscriteria op dit gebied geen taken woor de rechter zijn weggelegd. De sociale grondrechten richien zich tot de regelgevende of besturende organen van de overheid: TK 1975-1976, 13873 , nr. 8. p. 7.

35 De mintmum momen woor socille zakerheid zilin vastgeltegd in LO-verdiag 102 en De Europese Code woor sooide zekorheid. Art. 12 lid 2 ESH verplicht de werdiagspartijen on het stelsel wan socials zekerheid te bouden op en bevredigend peil datt ten minste gelijk is asan het peil dat door ILO-verdrag 102 wordt gewairborgd.

36 Zie voor en derge ijke toetsing bijv.: TK 1992 1993, 22 824, ar. 3, p. 70-72 (TBA); TK 1995-1996, 24 439, nir. 3, p. 48-52 (WULBZ) en TK 1994-1995, 24 169, nw. 3, p. 16-20 (ANW). Opwallend is dat en dergelijke toetsing in do MVIT bij het wetswoorstel vooi de nienwe bijstandsregeling (Wwb) ontbreekt, 2eker nu art. 8 wan dit wetswoorstel gemeenten de beweegdheid geeft om op basis wan aen verordening de bijstandsnorm te vertagen: TK 2002-2003, 28870 , ar. 1-2; p. 5. Overigens is in de MvT, op instigatie van de Raad van State, wel een paragrat fewijd aan de verengbaarheid wan een eventuele verlaging wan de bijstandsinom (als sanctie) met do disen wan art. 6 EVRM (is zo"n matregel bijv. een punitieve sanctie in de zin wan dat verdrag?): TK $2002-2003,28870$ A, p. 14 en nr. 3, p. 49 . De voorgenomen hervorming van de WAO wordt, zonder dat datar al een concreet wetswoorstel voor is, momenteel wel getoetst op de vratag of de voorgenomen herzicning overeenstemt met internationale normverdagen (zie dearvoor bijw: Handelingen TK. 2002-2003, Aanhangsel 702, p. 1477 en de brief van de minister van Sociale Zaken aan de Tweede Kamer van 31 januari 2003. ar. 03/9184). Met name de normen van $1 \mathrm{LO}$-verdrag 128 met betrekking tot de uitkeringsbedragen bij grbeidsongewallen en beroepsziekten zijn hier in het geding. Bij deze oorzalken van arbeidsongeschiktheid moet minmaal $50 \%$ van het laatstwerdiende loon worden gegarandeerd zolang de arbeidsongeschiktheid duturt (art. 6 onder o van dit verdrag). Bij overgang naar de werkloosheidsregeling kan deze nom in het gedrang komen. Ook ten aamzien van niet arbeidsgebonden worzaken van arbeidsongeschiktheid kan dit een 
obstakels op. Het niveau van de Nederlandse sociale zekerheid ligt in het algemeen boven de vastgestelde minimumnormen en bovendien gaat modernisering van het stelsel in de regel niet gepaard met volledige intrekking van de waarborgen die in 1983 bestonden. Voor zover er wel problemen dreigen, bestaat de neiging daarvoor 'creatieve' oplossingen te zoeken, bijvoorbeeld door een 'problematisch' verdrag niet te ratificeren of de opzeggingsmogelijkheden af te tasten. ${ }^{37}$

Dit kader geeft ruime mogelijkheden voor aanpassing van het stelsel, ook in neerwaartse richting. ${ }^{38}$ De beslissing om af te zien van een nadere definitie van het begrip sociale zekerheid helpt hieraan ook een handje mee. Ook dit laat de wetgever immers nimte om, afhankelijk van de omstandigheden, te bepalen hoe de opdracht om op het terrein van de sociale zekerheid regelend op te treden, nader wordt uitgewerkt. ${ }^{39}$ Deze beleidsruimte komt uiteraard goed van pas in tijden waarin in beleidskringen de overtuiging leeft dat het sociale

probleem zijn ondat art. 9 lid 3 wan ILO-werdrag 121 tijdelijke uitkeringen bij structurete arbeidsongeschiktheid niet toelaat. Voor deze toetsing is verder wan belang dat het Internationale Arbeidsbufean van de ILO waarborgen heeft opgesteld die bij een priwate uitvoering in acht genomen moeten worden (er mogen bijv. geen werknemers buiten de boot vallen en de werkgever moel zich kunnen verzekeren). Zie hierower nader ook par. 10.2 .

37 Een voorbeeld van een verdrag dat bewast niet is geratificeerd is ILO-verdrag 168 inzake de bevordering van werkgelegenheid en bescherming tegen werkloosheid (zie daarvoor bijv. TK 2000-2001, 27 480, nr. 1). Op grond van dit verdrag moeten tiitkeringen bij werkloosheid minimal $50 \%$ van het vroegere loon bedragen. De in art. $52 \mathrm{a}-\mathrm{j}$ WW verankerde kortdurende werkloosheidsuitkering ( $70 \%$ wan het minimumloon gedurende een half jaar) voldoet niet altijd aan deze norm. Ook het aangescherpte suncticbeleid op grotud van de Wet Boeten en Maatregelen (1996) staat op gespannen voet met de nornen wan LLO-verdrag 168. Zie daarvoor nader: F.JL. Pennings, De bevordering van werkgelegenheid en bescherming tergen werkloosheid, in: Het Nederlandse sociale zekerheidsrecht en de minimumnormen van de $L A O$ en do Raad van Europa, Deventer Kluwer 1992, p. 108. Een andere 'creatieve' oplossing is opzegging van een 'problematisch" verdrag. Nadat art. 26 IVBPR van toepassing was verklaard op het stelsel wan sociale zekerheid, is overwogen dal verdrag op te zeggen en opnieuw te ratificeren net een voorbehoud bij ant. 26 resp. on het individuele klachtenrecht bij dit verdrag op te zeggen (zie voor reacties daurop bijv. NJB 1988 , p. 378). Opzegging is ook overwogen bij de totstandkoming van de ANW wegens twijfel of de wijziging waarbij de nabestandenuitkeringen inkomensaflarakelik zign genaake wel in overeenstemming is mol deel WI wan ILO-verdrag 121 en de Gurypese Code inzake sociale zekerheid. Tijdens de partementaire behandeling wilde de regering dil problem oplossen door deel VI van beide verdiagen op te zeggen (TK 1994-1995, 24 169, nr. 3, p. 19). Tegensund in

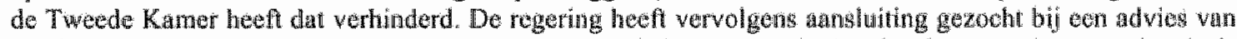
het Intermationale Arbeidsbureas, wakrin werd gesteld dat geen uitkering hoef te worden toegekend als daarwoor geen sociale rechtvaardiging bestaht, bijv. omdat nabestanden woldoende inkomsten of andere bestuansmiddelen hebben. Hieruit werd afgeleid dat de inkomensathankelijkheid vain de nabestandennitkering dus door de beugel kon.

38 Art. 12 lid 3 ESH en art 11 IVESCR werplichten weliswar te gitrewen natar en geleidelijke verhoging wath het sociale zeketheidspeil, maar het effect daarvan is gering door de open formulering wan deze bepalingen. Ten adnzien van ant. 12 lid 3 ESH heeft de CR $w B$ geoordeeld dat deze bepaling niet kan worden aangemerk als een "een ieder verbindende" bepaling zodat deze zicli niet leent voor rechterijike toetsing (CRvB 10 augustuss 1988, RSV 1989, 94). Wijzigingen in neerwaratse richting kunnen als gevolg hiervan niet met een berotp op deze bepalingen worden tegengehouden.

39 Van nadere definiering van het begrip sociale zekerheid is afgezien om te woorkomen dat de opdracht on op dit gebied regelend op te treden te zeer het karakter krijgt van een politiek program. Zodra word aangegeven waaruit de aanspraken op sociale zekerheid dienen te bestaan dreigit bowendien het gevaar dat do opsomming willekeurig is. Ook zou daardoor de indruk kunnen worden gewekt dat er slechts ên vorm denkbaar is warin deze atnspraken gestalte kunnen krijgen. Dat zou afbreuk doen aarn het feit dat dic aanspraken op diverse wormen kunnen worden uitgewerkt: TK 1975-1976, 13 873, nr. 1-4, p. 12 en 1976-1977, nr. 7, p. 3. 
zekerheidssysteem drastisch moet worden aangepast om de houdbaarheid en betaalbaarheid daarvan te garamderen. Het juridisch kader laat immers toe dat de wetgever, bij de afwegingen die zullen moeten worden gemakt tussen hetgeen relevante sociale grondrechten de burger beogen te verzokeren en andere beleidsdoelstellingen, prioriteiten stelt. Niet witgesloten is hierdoor dat andere doelstellingen: in dit afwegingsproces zwaarder gaan wegen. Recht doen aan de sociale grondrechten brengt immers wak investeringen (en dus kosten) mee en de financiele middelen zijn nu cenmaal niet onbeperkt.

\section{Consequenties voor de kwaliteit van de moderniseringwetgeving}

\subsection{Financieel-economische belangen overheersen}

Uit de inmiddels doorgewoerde wijzigingen blijkt dat de wetgever volop gebruik heeft gemakkt van de beleidsruimte om in het licht van de feitelijke mogelijkheden en relevante politieke en sociaal economische omstandigheden te bepallen hoe de grondwettelijke opdrachten in de steer van de sociale zekertheid wotden ingekleurd. In veel gevallen hielden die wijzigingen aanpassingen in neerwaartse richting in. Veelal werd dit gerechtvaardigd met een beroep op de bijdrage die deze aanpassingen zouden leveren aan de bevordering van arbeidsparticipatie en, daarmee, aan de economische zelfstandigheid van betrokkenen." Op het eerste gezicht lijkt daarmee recht te worden gedaan aan de algemene strekking van de sociale grondrechten om 'aandach te besteden aan de bestaanszekerheid van de mens en het streven naar zijn individuele en maaschappelijke ontplooing'. In werkelijkheid domineren echter hele andere belangen. Onder het mom van modernisering denkt men namelijk tegelijkentijd aanzienlijke bezuinigingen te kunnen realiseren. ${ }^{42}$ In een periode waarin beheersing van de collectieve lasten hoog op de politieke agenda staat, zet dit financiẻle argument gewichtige zoden aan de dijk. Dat wordt echter gemaskeerd door de wetswijzigingen te "verkopen" onder de vlag van de bijdrage die deze wijzigingen aan de bevordering van arbeidsparticipatie kunnen leveren.

Deze werlkwijze heeft de nodige consequenties. Zo is bevordering van arbeidsparticipatie hierdoor, als puntje bij paaltje komt, geen doel op zich, maar eerder een middel om bezunigingen te realiseren. Dit heeft op zijn beurt zijn weerslag op de instrumenten die worden ingezet on tot bevordering van arbeidsparticipatie te komen. Ook die worden niet zo zeer gokozen op grond van bun geschikthaid om een duurzame integratie in het arbeidsproces te realiseren, mar eerder op grond van de mate waarin zij de beoogde besparingen kunmen helpen verwezenlijken. De doelstelling om te komen tot een hoger niveau wan arbeids-

40 TK $1976-1977,13,873$, ar. 7, p. 2.

41 Zie bijw. TK 1994-1995, 24 169 (ANW) en TK 1992-1993, 22824 (TBA). Zie hiervoor nader ook: P.F. van der Heijden en F.M. Noordan, De wande(n) van het soetaal recht; over beginselen van rechtsworming en hun werking, Deventer Tjeenk Willink 2001, p. 56-64.

42 De matrogelen van de TBA, die lun beslag hebben gekregen in het huidige art. 18 en 21 a en $21 \mathrm{~b}$ WAO, zouden bijw. leiden tot een bezuiniging wan 4,5 miljard gudten; wan de modernisering van de nabestaandenregeling werd een besparing van 1,3 miljard werwacht en de priwatisering van de ZW zon 900 miljoen gulden opleveren: TK 1992 1993, 22824 , nr. 3, p. 69 resp. TK 1994-1995, 24169 , nr. 6, p. 40. Zie ook: Kabinet Kok, Keuzen voor de Toekomst, Den Haag SDU 1994, p. 47 . 
participatie komt hierdoor gemakkelijk op de tocht te stan: Ook de grondrechtelijke op dracht om daarbij matregelen te nemen die bujdragen aan de imdividuele en maatschappelijke ontplooing verdwijnt hierdoor al snel naar de achtergrond.

\subsection{Wetgeving met een dubbele bodem}

De argumenten achter het besluit om het publiekrechtelijke ziekengeld om to zetten in de verplichting van de werkgever om bij ziekte het loon door te betalen, geven hierwan een aardige illustratie. Deze ingreep werd verkocht als instrument om de arbeidsparticipatic van zieke werknemers te bevorderen: als werkgevers de kosten van ziokteverzuim maar rechtstreeks voelen in hun portemonnee, dan zullen zij zich vanzelf wel gaan inspannen om, met een actief preventie- en reïntegratiebeleid, te voorkomen dat werknemers door ziekte (langdurig) uitvallen. Aanvankelijk werd deze gedachte geconcretiseerd in een loonbetalingsplicht die zich woor grote werkgevers beperkte tot de eerste zes weken wn voor kleine werkgevers tot de eerste twee weken wan het ziekteverzuim. ${ }^{44}$ Zonder het effect hiervan af te wachten, werd de loonbetalingsplicht echter kort daarna voor alle warkgevers verlengd tot het hele eerste ziektejaar. ${ }^{45}$ Werkgevers zouden hierdoor sterker worden geprikkeld om het ziekteverzuim in hun bedrijf zo minimaal mogelijk te houden en, daarmee, een extra impuls krijgen om hun steentje bij te dragen aan de bevordering van de arbeidsparticipatie van zieke werknemers. ${ }^{46}$

Tegelijkertijd werd echter onderkend dat werkgevers hierop wel eens zouden kunnen reageren door het risico van loondoorbetaling bij ziekte massaal onder te brengen bij particuliere verzekeraars. Hoewell werkgevers hierdoor niet langer direct met de kosten van ziekteverzuim zouden worden geconfronteerd, en een essentieel onderdeel van de prikkelfilosofie daarmee ongedaan gemaakt zou worden, werd aan dit neveneffect niet zwaar getild. Belangrijker was dat de lasten van het ziekterisico door deze maatregel voor een groot deel bij werkgevers kwam te liggen en dat dit een bezuniging van 900 miljoen gulden zou opleveren. ${ }^{47}$ Dit blijkt bijvoorbeeld wit het feit dat tijdens het wetgevingsptroces wel energie is gestoken in een nader onderzoek naar de daadwerkelijke verzekeringsmogelijkheclen op de particuliere verzekeringsmarkt, maar niet is nagegaan of de veronderstelling dat uitbrei. ding van de loonbetalingsplicht zal leiden tot intensivering van het preventie- en reintegratiebeleid en, daamee, tot reductie van het ziekteverzuim, wel klopte. Dit werd zonder enige onderbouwing aangenomen.

43 Zie hierwoon biju. TK $1989-1990,21300 \mathrm{XV}$, nr. 65.

44 Deze matregel was op 1 januari 1994 ingegaan via de Wet Terugdringing Ziekteveraim (TZ), wh van 22 december 1993 . Sitatsiblad 1993,750.

45 Deze veriengde loonbetalingsplicht ging in op I mart 1906 via de We Uibreiding Loonbetalingsplicht bij Zlekte (WULBZ); wett wan 8 februari 1996, Statsblad 1996, 134. Deze plicht kreeg zign beslag in art. 7:629 $B$ W ent $29 \mathrm{ZW}$

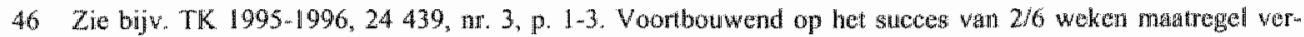
wach de regening van deze verlengde loonbetalingsplicht een verdere teducte van bet zieleventuin met $10 \%$.

47 Deze maatregel had bovendien als bijkomend voondee dat witvorders door concurrentie op de verzekeringsmarki zouden worden geprikkeld tot een achef en doeltreffend prevertie on reintegrainebleid: TK 1995 . $1996,24439 \mathrm{nr}, 6, \mathrm{p}, 25 \cdot 27$ 
Het risico dat de verlengde loonbetalingsplicht in werkelijkheid niet het beoogde arbeidsparticipatiebevorderde effect zou hebben werd daarmee in wezen ondergeschikt gemaakt aan de bezuinigingsdoelstelling die door de nieuwe wijze van financiering van het ziekterisico kon worden werwezenlijkt. In de kern was dit de spil waar de wetswijziging om dralaide. Tijdens de parlementaire behandeling is in dit licht ook relatief veel aandacht besteed aan de eventuele negatieve effecten die zouden kunnen optreden door de, met deze nieuwe financieringsvorm gepaard gaande, overgang van een publieke naar een private verzekeringsvorm. Als gevolg hiervan is de Ziektewet niet helemaal afgeschaft maar als vangnet voor bepaalde groepen blijven bestaan en zijn ook afspraken gemaakt met het Verbond van Verzekeraars om te waarborgen dat werkgevers al hun werknemers zonder selectie tegen een redelijke prijs konden verzekeren. ${ }^{49}$

Dit wil overigens niet zeggen dat de prikkelfilosofie voor zoete koek werd geslikt. Er werden wel degelijk kanttekeningen geplaatst bij de wankele basis daarvan. Zo werd bijvoorbeeld nadrukkelijk gewezen op het gevaar, dat verschuiving van de financiële verantwoordelijkheid voor ziekteverzuim naar werkgevers, tot scherpere risicoselectie an de poort en een stringenter ontslagbeleid zou kunnen leiden. ${ }^{50}$ Dit bezwaar heeft de uitbreiding van de loonbetalingsplicht echter niet kunnen verhinderen. Het werd min of meer weggepoetst met de toezegging dat er wettelijke maatregelen zouden komen om dit probleem te ondervangen als zou blijken dat een oplossingen via "de markt" niet zou werken. ${ }^{51}$ Met de nodige politieke stuurmanskunst werd zo een wet door het parlement geloodst waarmee de Zlektewet goeddeels werd geprivatiseerd zonder dat er duidelijke bewijzen waren dat die privatisering ook daadwerkelijk het beoogde gedragseffect zou hebben en wel in die zin dat

48 De Raad van State heeft hierin een belangrijke rol gespeeld. Zo beeft die Raad er in haar advies op gehanerd dal deze operatie onder social anwarardbare condities moest wonden uitgevoerd. Verschuiving van verantwoordelijkheden nas de particuliere verzekeringsmarkt ontslaat de overheid niet wan de takk te zorgen voor een wettelijk kader dat mogelijke negatieve effecten van de marktwerking opvangt, zodat een nieuw evenwicht ontstat tussen eigen inspanningen en initiatief en mantschappelijke solidariteit: TK 1995-1996, 24439

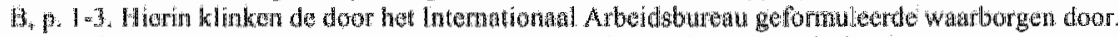

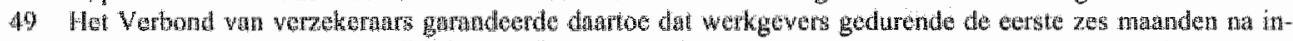
wertingteding wa de WULBZ hun werknemers collectief konden verzekeren zonder dat daubij gezond. heidsverklaring van individuele werknemers hoefden te worden overhadigd en zonder dat mensen met

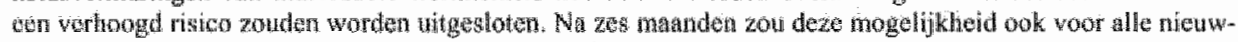
komers bestan. Zie hicrwoor bijw. TK 1996-1997, 24 439, nr. 18 en de rapporten wan het Vertond van Ver-

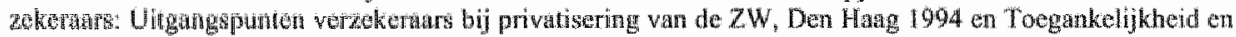

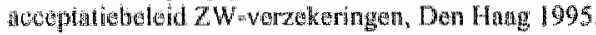

50 Dharbij werden twee rapporten wan het CTSV in stelling gebracht waruit bleek dat de neiging tot risicoseleotie doof de $2 / 6$ matregel on de maltas inderdaad was toegenomen: $S$. Andriessen, T J Veerman on J. Wigen, Risicoselectio op de Nedertandse Arbeidsmarkt, Zoetermeer 1995 en J. Vijgen, Een jatir terugdringing ziekteverzaim; affeten en neveneffecten vas financible prikkels, Zoetermeer 1995. Pikant in dit verband is dat het desakundigencomite dat betast is met het toozicht op de nalleving van de Europese Code woor

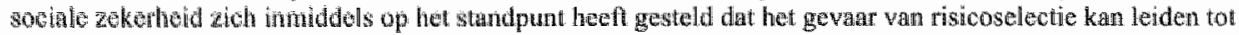
doorbroking van de solidwriteir tussen werkgevers en werknemers. Het is hierdoor matr de wragg of de rechten van werknemers wel afdoende gewaarbongd zijin. Tot nu toe heen het Comité van Ministers wan de Rad van Euopa cohter nog geen aabevelingen gedwan orn de Nederlandse wetgeving aan te passen.

31 Met oplossingen viu "de markt" werd gedoeld op de totstandkoming van een protocol waarin de regulering wan de ansiellingskeuring zou worden geregeld. Er lag op dat monent at een inithatief wetsworstel voor de regulering van de atanstellingskeuring: TK 1992-1993, 23259, ar. 1-2. 
werkgevers daardoor geprikkeld zouden worden om zich in te spannen voor de bevordering van de arbeidsparticipatie van zieke werknemers. ${ }^{52}$ De effectiviteit van dezo ingreep werd hierdoor op dit punt op voorhand al op losse schroeven gezet.

\section{$5.3 \quad$ Vasthouden ande ingezette koers}

De praktijk heeft inmiddels aangetoond dat uibreiding van de loonbetalingsplicht niet auto matisch leidt tot vermindering van het ziekteverzum. Toch is de wetgever als gevolg hiervan niet teruggekeerd op zijn schreden. In plaats van nu eens grondig te onderzoeken of het beoogde doel (vermindering van ziekteverzuim door bevordering van arbeidsparticipatie) überhaupt wel met financiële prikkels kan worden bereikt, wordt gewoon vootgegaan op de ingeslagen weg en doen nieuwe financiële prikkels hun intrede. Zo verschijnt in 1998 de PEMBA op het toneel. ${ }^{53}$ Voortbordurend op de prikkelfilosofie beoogt deze wet werkgevers opnieuw een impuls te geven om het ziekteverzuim binnen zijn bedrijf binnen de perken te houden door actief aan preventie en reintegratie te doen. Hoewel dat dit keer via differentiatie van de WAO-premic of de mogelijkheid wan eigenrisicodragerschap moet worden gerealiseerd, wordt hiermee voortgegaan op de ingeslagen weg, tarwijl er nog steeds geen overtuigende bewijzen zijn dat daamee het beoogde resultaat kan worden bereikt. ${ }^{54}$ Tijdens de parlementaire behandeling wordt dit opnieuw aan de orde gesteld. Behalve op het feit dat werkgevers niet alle vormen van ziekteverzum met een actief preventie en reïntegratiebeleid kunnen beinvloeden (de oorzaken daarvan liggen immers voor een deel buiten de arbeidsorganisatie), wordt in dit verband wederom gewezen op het gevaar van vluchtgedrag in de vorm van een toenemende kans op risicoselectie aan de ondernemingspoort ${ }^{55}$ Deze kritiek baat echter niet. De meerderheid van het parlement steunt de voorgestelde maatregelen en neemt genoegen met een pakket flankerende mantregelen die tot doel hebben onbedoelde gedrageffecten te corrigeren. ${ }^{56}$ Reparaties moeten eventuele gebreken dus maar verhelpen.

52 Er was wel en GTSV-rapport dat weeg op het tegended: R.JJ, wan Lochen en $Y$. Wijnands, De werkgever

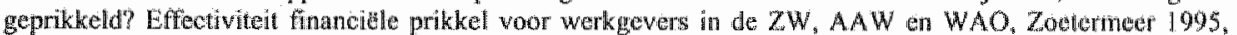
met mame p. 8 en 67 .

53 De PLMBA werd ingevoerd op 1 januari 1998, Statsblad 1998, 175.

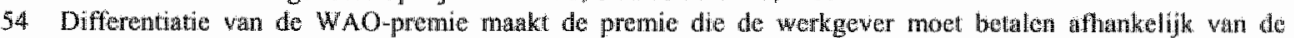
relatieve uitkeringsianten die zijn werknemers de eerste vijf jar wan hun arbeidsongeschiktheid weraorzak on.

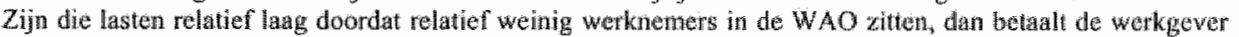
een lagere premie. In het omgekeerde geval betaalt de werkgever earn hogere gedifferentieerde premic, naast de bisispremie woor de WAO. Zie ari. 76 a $\mathrm{b}, 78,79$ a en 79 b WAO. Eigen risicodragershap brengt mec

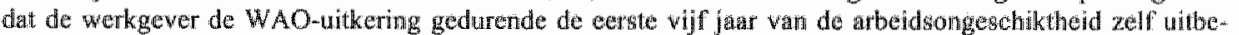

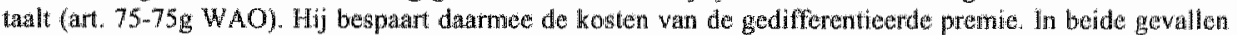

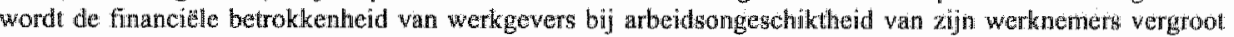
en dat moet leiden tot intensiwering van het preventie en reintegraticbeleid.

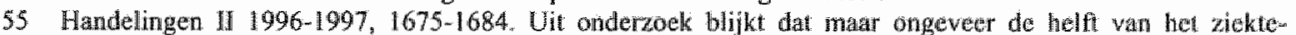
verzuim gerelaterd is atan de arbeidssituatie. Zie darvoor bijy. P.C. Hermans en R. Prins (red.), Causaliteit en arbeidsongeschiktheid. Zoetermeer 1993, p. 71 .

TK. $1995,1906,24698$, ni. 3, p. 7 


\subsection{Positieve financtele prikkels als tegenwicht}

\subsubsection{Doeltreffend medicijn?}

Met de introductie van de Wet REA op 1 juli 1998 krijgen deze reparaties voor een belangrijk deel hun beslag. ${ }^{57}$ Om de neiging tot nisicoselectie in te dammen beoogt deze wet het werken met mensen, die door gezondheidsproblemen van deelname aan het arbeidsproces dreigen te worden uitgesloten, yoor werkgevers financieel aantrekkelijk te maken. ${ }^{58}$ Dit gebeurt voomamelijk door werkgevers een scala van financiële voordelen te bieden als zij deze "arbeidsgehandicapten' in dienst nemen of houden. ${ }^{59}$ Deze voordelen variëren van vrijstelling van de loonbetalingsplicht als een 'arbeidsgehandicapte' binnen vijf jaar na indiensttreding uitvalt wegens ziekte tot kwijtschelding of vermindering van de basispremie voor de WAO als de werkgever een bepaald percentage van zijn loonsom aan "arbeidsgehandicapte' werknemers besteedt. ${ }^{60}$ Daarnaast wordt weel verwacht van bij de Wet REA geïntroduceerde budgetten warmee de met reïntegratie gemoeide kosten snel, eenvoudig en vrijwel zonder administratieve rompslomp kunnen worden bestreden. ${ }^{6.1}$

Verondersteld wordt dat deze financiële voordelen werkgevers zullen stimuleren om "arbeidsgehandicapten" in dienst te nemen en te houden en ook dat de vereenvoudigde procedure hen zal aanmoedigen om van deze voorzieningen gebruik te maken. Dat is ook hard nodig want het vóór invoering van de Wet REA bestaande instrumentarium om reîntegratie te bevorderen blijkt nauwelijks te worden benut. ${ }^{62}$ Het instrumentarium van de REA moet hierin verandering brengen.Ondat de Wet REA voortbouwt op de prikkelfilosofie berust ook deze veronderstelling echter op drijfzand. De positieve prikkels die deze wet introduceert dienen in wezen als medicijn tegen de zwakheden van die filosofie, ${ }^{63}$ maar pakken de factoren die tot uitsluiting van bepaalde groepen leiden niet bij de wortel aan. In dit licht verbaast het niet dat inmiddels uit een evaluatie is gebleken dat het REA-instrumentarium niet de daarvan werwachte vruchten afwerpt. Volgens de evaluatie kan dit niet alleen

57 Wet wan 23 april 1998, Statwblad 1998, 290. Daamaasl word ook de Wet op Medische Keuringen ingevoert (wet wan 24 decenber 1997, Statsblad 1997, 770) die op I janwari 1998 van kracht werd. Hierop wordt ingegaan in par. 5.5 .

58 TK $1996-1997,25,478$, ar. 3, p. 28.

59 Volgens art. 2 wot REA is iemand van rechtswege 'arbeidsgehandicapt' als hij/zij een arbeidsongegchiktheidsuitkering ontvangt op grond wan de WAO, de WAZ of de WAJONG, een werkvoorzicning heef of behoor to de doelgroep van de WSW maar niet werkzam is als werknemer in de zin van de WSW of in een WSW dienstbewekking. Anderen kunnen op grond. van een medisch arbeidskundige verklaring het predikaat "arbeidsgelwandicapt" krijgen.

60) Deze maatregelen zijn werankerd in ant. 2962 W resp. art. 75 e en 776 WAO. De basispremie is niet verschuldigd als de werkgever vijf procent van zijn loonsom aan arbeidgehandicapten besteedt. Ligi dat percentage tussen do vier en de wijf procent dan is de basispremie voor $2 / 3$ deel niet verschuldigd on bij een percentage wassen de drie en de vier procent woor $1 / 3$ deel niet.

61 Art 16-18 Wet REA. De budgetfen gewen recht op een eenmalig bedrag wan $\mathrm{fl}$. 8000,- bij herplaatsing van een arbeidsgehandicapte werknemer in eef andere functie binnen het eigen bedrif en cen, over een periode van drie jaar gespreid, bedrag van fl. 24.000 , - als de werkgever een arbeidsgehandicapte in dienst neent.

62 Dit blijki bijw. vit de 2ARA werkgevers panel rapportage 1996-1997, SZW Dan Haag 1997. Opgemerkt wordt daabij dat het niet ondenkbar is dat de negatieve financite prikkels, zoals de verlengde loonbetaw lingsplicht en de PEMBA, hieran een steentje bijdragen.

63 Dat wordt ook met zoveel woorden angegeven: zia bijv. TK 1996-1997, 25 478, nr. 12, p. 21. 
worden toegeschreven aan het feit dat de regeling, ondanks de aangebrachte vereenvoudiging, in de praktijk toch nog steeds ondoorzichtig en gecompliceerd is. Gebleken is namelik ook dat de financièle voordelen, en meer in het bijzonder de budgetten waarin de Wet REA voorziet, voor werkgevers niet doorslaggevend zijn voor het in dienst nemon of houden van "arbeidsgehandicapten". Zij beschouwen het als een leuk extratje dat niet noodzakelijkerwijs wordt aangewend voor reïntegratiebeworderende investeringen. Het aantal subsidies is hierdoor Weliswar toegenomen, mar tot een grotere mate van arbeidsparticipatie van 'arbeidsgehandicapten' heeft dat niet geleid. ${ }^{64}$

\subsubsection{Nieuwe reparaties}

De regering heeft uit deze evaluatie de conchusie getrokken dat het bestaande systeem moet worden aangepast. Dit, hoewel de Raad van State maande tot voorzichtigheid on op basis van een eerste evaluatie ingrijpende veranderingen aan te brengen. De Raad van State wees er in dit verband op dat het bestaande systeem, mede door de in gang gezette reotganisutie van de uitvoeringsorganisatie, nog nawwelijks een kans heeft gehad om tot volle ontwikkeling te komen en bovendien ook geen reële kans krijgt on zich te stabiliseren als het nu al weer gewijzigd wordt. De regering heef dit advies echter in de wind geslagen cum anpassing van het bestaande systeem niettemin noodzakelijk geacht. Als gevolg hiervan zijn de budgetten van de Wet REA per 1 januari 2002 vervangen door een nieuwe regeling. Kern daarvan is dat de werkgever bij indienstneming van een "arbeidsgehandicapte" gedurende drie jaar een korting kan krijgen op een aantal premies die de werkgever voor die werknemer moet afdragen. Het gaat hierbij zowel om een koring op de (basis en de gedifferentieerde) WAO premie als om een korting op het werkgeversdeel van premies die aan het Algemeen Werkloosheidsfonds moeten worden betaald. Herplaatsing van een 'arbeids gehandicapte" in een andere functic in hetzelfde bedrijf of geheel of gedeeltelijk behoud van de eigen functie word beloond met een korting op dezelfde premies gedurende een periode van een jaar. 66

Vollgens de regering sluit deze regeling beter aan bij andere prikkols die ook via premiewrijstelling of premiekorting worden gerealiseerd. ${ }^{6}$ Do systematiek wordi zo vereenwoudigd en versoberd. Dit overigens nict alleen in administratieve maar ook in findncido zin. De nieuwe regeling makt de omvang van de financiéle tegemoetkoning immers afhankelijk van het loon van de desbetreffende werknemer en kan daardoor lager witwallen

64 TNO Arbeid, De realieit; integrale rapportage evaluatie Wet REA, Den Haag 2001, par. 3.1.

65 TK 2001-2002, 28016, A, p. 3 en 4. Zie voor geuite kritiek op de regeling lijdens de parlementaire behandeling bijv. TK 2001-2002, 28 016, nr. 22.

66 Deze regeling heft zijn beslag gekregen in het gewijzigde artikel 79b WAO resp. in art. $82,82 \mathrm{a}$ en $97 \mathrm{cWW}$ Zie voor thet wetsvoorstel: TK $2001-2002,28016$, n. 3. p. 3,7 en 8 . An beide gevallen kan dit bedrag eventueel worden aangevuld met een asnvullende subsidie waaruit de met reintegratio gemoeide kosfen kunnen worden bestreden. Het moet dan wel om rede kosten gaan. De werkgever moet dat dir athtonen (art. 15 en 16 Wet REA). Daarmee zijn we in feite weer "torug bij ar".

67 Gedoeld wordt op de prikkets van de PEMBA en de wrijstelling wan de basispremie woor de WAO 4ls de werkgewer ten minste drie procent wan zijn loonsom aan arbeidsgehandicapten besteed. Dexe regeling wijkf overigens af van het inmiddels ingetrokken art $77 \mathrm{~b}$ WAO wathin dit voor deze wijziging was geregeld. 
dan de voormalige budgetregeling. ${ }^{6 \%}$ De opmerking van de Raad van State dat dit tegelijkertijd het beoogde effect van deze financiele prikkel kan frustreren, wordt weggewuifd: door erop te wijzen dat uit het evaluatierapport blijkt dat de hoogte van de financielle tegemoetkoming de reîntegratie inspanningen van werkgevers toch niet of nauwelijks beïnvloedt. ${ }^{69}$ Hoewel dit juist een reden had kunnen zijn om dit instrument ter discussie te stellen, steekt men de prikkel kennelijk liever in een ander jasje zonder serieus na te gaan of dit eigenlijk wel zinvol is. Het risico dat uit de volgende evaluatie blijkt dat ook de premiekorting niet het beoogde effect heeft, blijft hierdoor bestaan. Waarom zouden werkgevers deze regeling immers niet als een leuk extraatje beschouwen? Nu deze regeling de link met daadwerkelijke reinntegratie inspanningen in feite nog losser maakt, ligt het in de lijn van de verwachting dat ook hiervan geen noemenswaardige impuls zal uitgaan om in reïntegratiebevorderende maatregelen te investeren.

De aangedragen oplossingen zijn op dit punt onvoldoende doordacht. Zij spelen niet adequaat in op de factoren die werkgevers daadwerkelijk tot risicoselectie bewegen en houden daarmee het mechanisme dat tot uitsluiting van bepaalde groepen leidt, in stand. De kans is hierdoor groot dat de ene maatregel zich maar op de andere blijft stapelen met als gevollg dat de regelgeving op dit terrein alleen maar complexer en ondoorzichtiger wordt en bovendien haar doel (bevordering van arbeidsparticipatie van de beoogde doelgroep) woortdurend voorbij blijft schieten. Om deze doelstelling te realiseren is een andere aanpak nodig die zich veel explicieter dan nu het geval is richt op doorbreking van het bestaande uitsluitingsmechanisme. Dit vereist een grondige analyse van de obstakels die aan het in dienst nemen of houden van de beoogde doelgroep in de weg staan en het besef dat financiële prikkels daarop in leder geval niet het antwoord zijn. ${ }^{70}$

\subsection{Regulering van de aanstellingskeuring}

Financiële prikkels zijn overigens niet het enige middel om onbedoelde gedragseffecten, zoals de neiging tot risicoselectie aan de poort van de onderneming, in te dammen. De eveneens in 1998 ingevoerde Wet op de Medische Keuringen beoogt hieraan bijvoorbeeld paal en perk to stellen door het gebruik van aanstellingskeuringen aan banden te leggen. Sinds 1998 zijn aanstejlingskeuringen als gevolg hiervan alleen toegestaan als de werkgever iemand wil aanstellen in een functie die bijzondere eisen stelt aan de medische geschiktheid van de werknemer. ${ }^{71}$ De wet schrijft verder voor dat werkgevers in de sollicitatiefase geen informatie mogen inwinnen over de individuele gezondheidstoestand.

68 De premiekorting bedratagt 1021 euro voor zowel de WAO-premics als de relevante premies die aan het AWF moeton worden afgedragen. Bij ministeriele tegeling worden nadere regels gesteld over de verdeling van de korting aver de relevante premies voor de verschillende regelingen. De budgetten bedroegen daaremtegen gemiddeld f1. 8000,- per jaar. Zie voor deze bedragen art. 79b WAO en art. 82, 82a en 97o WW. Met dezo nieuwe regeling kan, naar verwachting, een bezuinging worden gerealiseerd van 332 miljoen gulden. Zie daarvoor bijw. TK $2001-2002,28016$, nr. 22, p. 8 .

69 TK 2001-2002, $280116, A$, p. 5 .

70 Zie voor een andere bentedring par. 9.

7 Aft. 4 lid 1 en 2 WMK. Dit geldt ook voor keuringen bij het aangann wan (aanvullende) particuliere verzekeringen, zoals ein verzekering die het risico van loonbetaling, bij ziekte dekt of andere, aanvullende arbeidsongeschiktheidsverzekeringen, bijw. verzekeringen ter dekking van het "WAO-gat". 
Het stellen wan vragen over de gezondheidstoestand van de solhoitant is uitdrukkelijk voorbehouden aan de arbo-arts die de keuring verricht. ${ }^{22}$ De WMK kiest dammee voor een andere invalshoek. Voorkoming van risicoselectie is weliswaar een belangrijke doelstelling van de deze wet, maar de waarborgen die daarvoor in deze wet zijn neergelegd ziju primair geformuleerd vanuit privacy perspectief. ${ }^{73}$

Ook dit brengt echter de nodige problemen mee, die de bijdrage die de WMK in principe kan leveren aan verhoging van de arbeidskansen van mensen met gezondheidsproblemen, kan ondergraven. Zo biedt de WMK geen volledige garantie tegen selectie aun de poort. Het verbod om informatie in te winnen over de gezondheidstoestand belet werkgevers immers niet on uit het arbeidsverleden of de hobby's die iemand heeft (zoals een gevaarlijke sport) mogelijke gezondheidsrisico's af te leiden. Bovendien betekent het leit dat de werkgever niet naar de gezondheidstoestand mag vragen niet automatisch dat de aspirant werknemer daarover geen mededelingen hoeft te doen. Als hij beperkingen heeft die de uitvoering van de desbetreffende functie kunnen belemmeren dan brengen de regels van de precontractuele redelijkheid en billijkheid mee dat hij de werkgevet daarvan in iader geval in de eindfase van de onderhandelingen op de hoogte stelt. Alleen over medische beperking die voor de uitoefening van de functie niet rechtstreeks van belang zijn, unag worden gezwegen. $^{74}$

Hoewel het doen wan dit soort mededelingen, al was het mal met het oog op het treffen wan eventuele werkvoorzieningen, van belang kan zijn om de kans op een duurzame arbeidsparticipatie te vergroten, kan deze mededelingsplicht de sollicitant toch voor een dilemma platsen. In het huidige bestel kunnen dit soort mededelingen namelijk ook tot gevolg hebben dat de werkgever de onderhandelingen afbreekt. Aldus wordt precies het tegenovergestelde resultaat bereikt. Het vrijblijvende karakter van het bestaande systeem werkt dit min of meer in de hand. De werkgever loopt immers hooguit financiéle woordelen mis als hij besluit mensen met functionele beperkingen uit zijn arbeidsorganisatie te weren. Het systeem legt op werkgevers geen enkele plicht om een sollicitant aangepast werk aan te bieden, laat staan on te onderzoeken of bepaldde functionele beperkingen wellicht doot een REA-voorziening zouden kunnen worden opgeheven. Alleen de genoemde financitule wootdelen kunnen de werkgever in geval van twijfel ower de streep trekken en doen besluiten om de sollicitant ondanks zijn beperkingen toch aan te nemen. Zoals al werd aangegeven is dat echter Jang niet altijd voldoende om een succesvolle reintegratie te realiseren. Ook hier schiet het instrumentarium om tot bevordering van arbeidsparticipatie te komen dus tekort. $^{75}$

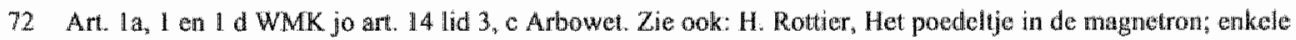
onderwerper un het wetswoorstel Arbeidsornstandigheder 1998 kritseh beschouwd an C.A.M. Mul k. a.,

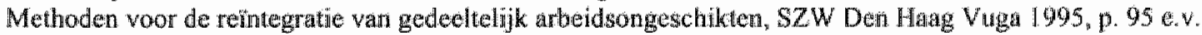

73. Volgens de parlementaire stukken is de wet primar bedoeld om de persoonlijke lavenswfeer en de

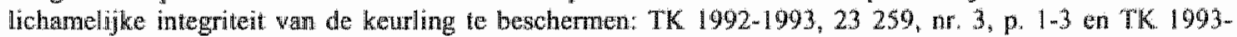
1994,23259 nir. 7, p. $1-2$.

74 Zie darower bijw. Rb. Rotwerdam I april 1999, JAR 1999, 99 en ant. 7:629 lid 3 a IEW.

75 Zie over dewe problematek nader: A.C. Hendrik, Geilike toegang tot de arbeid voor gehandicapten, Kuw lor Deventer 1999, p. 199-203. Volgens Hendriks behoort de mededtingsplicht van de sollientant te corres- 


\subsection{Voorlopig sluitstuk}

\subsubsection{Beperking van de toegang tot de WAO}

Zoals te verwachten was, heeft het pakket positieve en negatieve financiele prikkels het gestaag groeiende beroep op de WAO niet kunnen siuiten. Het beroep op die wet is de laatste jaren ongestoord blijven toenemen. In juni 2000 werd daarom de adviescommissie Donner ingesteld. Deze commissie kreeg de opdracht het 'WAO-probleem' nu eens grondig door te lichten en op basis daarvan met wijzigingsvoorstellen te komen. Deze wijzigingsvoorstellen zijn inmiddels bekend. ${ }^{76}$ Vertrekkend vanuit het standpunt dat de kern van het "WAO-probleem" ligt in het feit dat veel mensen onnodig de WAO in worden gedreven doordat het proces dat uiteindelijk tot een WAO-uitkering leidt, al na een paar maanden vrijwel ongrijpbaar is voor alle betrokkenen, zet de commissie in op een systeemverandering. Zonder verandering van perspectief zal het 'WAO-probleem' volgens de commissie niet verdwijnen. Om dat probleem aan te pakken, moet het accent daarom verschuiven van ziekte naar arbeidsgeschiktheid en van uitkering naar werk. Daarvoor is een omslag nodig die voornamelijk door een andere visie op arbeidsongeschiktheid moet worden gerealiseerd. Volgens de adviescommissie is arbeidsongeschiktheid in deze tijd niet langer een toestand die zonder meer inkomensbescherming rechtvaardigt. Het is een toestand die meer en meer affankelijk is geworden wan de wil en de inzet van de daarbij betrokken partijen. Zolang er nog resterende arbeidsmogelijkheden zijn moet daarom alles in het werk worden gesteld om deze mogelijkheden te gelde te maken door deze om te zetten in werk. De WAO kan zo gereserveerd blijven voor degenen die geen reële arbeidsmogelijkheden meer hebben en dus écht arbeidsongeschikt zijn. Voor degenen die ondanks hun functionele beperkingen nog kunnen werken wordt loon het primaire alternatief. Lukt het niet om resterende arbeidsmogelijkheden om te zetten in werk, dan ligt overgang naar de werkloosheids- en de bijstandsregelingen in het verschiet. ${ }^{77}$

In wezen is deze systeemverandering opnieuw een variatie op hetzelfde thema. De voorgestelde herdefinierring van het arbeidsongeschiktheidsbegrip is immers in feite een middel om mensen met functionele beperkingen met een financiële prikkel te stimuleren tot een grotere mate van arbeidsparticipatie. Slagen zij er niet in om aan het werk te blijven dan zal aanspraak moeten worden gemelakt op een werkloosheidsuitkering waardoor zij na verloop van tijd op het bestaansninimum aangewezen dreigen te raken. Het vooruitzicht van de forse inkomensachteruitgang die hiermee gepaard kan gaan, moet mensen met functionele beperkingen een extra stimulans geven om ledere kans op werk aan te grijpen. Het realiseren van een succeswolle werkhervatting krijgt hiermee een zwaar accent. In feite is dat een

potudeten mot een plichi wan de werkgever on te onderzoken of het werk, al dan ntet met een REAwooziening, kan worden angepast. Deze anupassingsphticht wan de werkgever behoort niet alleen te bestaan als de sollicitant wit cigen beweging melding makt wan voorzienbare functionele beperkingen, maar ook als hii con anastellingskeuring hoef ondergain en geclausuleerd positief is bevonden, Hij stelt voor deze verplichting in een aparte bepaling, bijw, in art. 12 a WMK, wast te leggen. Zie daarvoor p. 298 wan eerdergenoend werk.

76 De Adviescommissie "Donner" werd ingesteld bij besluit wan 28 juni 2000 . Haar rappont kwam ail op 31 mei 2001 onder de naatn "Work maken wan arbeidsgeschiktheid".

77 Zie daurvoor bijw. p. 76-79 en $101-109$ wan het rapport Werk maken van Arbeidsgeschiktheid. 
cruciale sclaakel in het hele plan. Zonder een snelle en doeltreffende omzetting van ziekteverzuim in werk bestalat immers een reêel gevaar dat het plan van de commissie Donner per saldo slechts leidt tot overheveling van mensen met functionele beperkingen naar de werkloosheidsregelingen, waardoor in de toekomst een 'werkloosheidsprobleem' dreigt te ontstaan. De commissie onderkent dit probleem, maar windt dit geen reden om vas haar plan af te zien. Zelfs als zou blijken dat het 'WAO-probleem' wordt doorgeschoven naar de werkloosheids- en de bijstandsregelingen dan is dat in thaar ogen nog altijd winst ondat zo kan worden voorkomen dat allerlei problemen worden gemedicaliseerd en mensen daardoor onnodig worden afgeschreven. Van het voorstel afzien op grond van mogelijke nadelen voor betrokkenen, onopgeloste problemen of koudwatervrees betekent volgens de conmissie gevangen blijven in het heden en dat is haar ogen nog een veel slechter plan. ${ }^{78}$

Over dit plan heeft de SER inmiddels advies uitgebracht. In dat advies heeft de SER het plan van de adviescommissie Donner in grote lijnen omarmd, zij het dat de SER wel heeft voorgesteld de scherpe kantjes daarvan hier en daar wat te verzachten. ${ }^{79}$ In het Strategisch Akkoord 2002 heeft de inmiddels demissionaire regering dit SER-advies grotendeels overgenomen. ${ }^{80}$ Uit het Hoofdlijnenakkoord van 16 mei 2003 blijkt dat het nieuwe kabinet zal voortgaan op dit pad. ${ }^{81}$ Dat lag ook in de lijn van de verwachting. In de politieke kraam komt dit hervormingsplan namelijk goed van pas. Zonder twijfel zal dit plan er immers aan bijdragen dat het aantal WAO-gerechtigden in de toekomst eindelijk zal afnemen.

\subsubsection{Flankerende maatregelen}

Aan het 'verplaatsingsgevaar' dat het hervormingsplan woor de WAO kan meebrengen, wordt tot nu toe niet zwaar getild. Aangenomen wordt dat de inmiddlels ook in werking

78. Zie daarwoor 139-143 van het rapport Werk maken van Arbeidsgeschiktheid.

79. Die verzachting heeft met name betrekking op het uitgangspunt dat het niet vinden wan werk voor alle betrokkenen tot overgang naar het werkloosheidscircuil leidt. De SER makt daartoe cen onderscheid tussen mensen met lickte arboidsbeperking (bot uiting kornend in een arbeidsongeschilatheidspercentage van $0.35 \%$ ) en mensen met een behoorlijke arbeidsbeperking (tot witing komend in wen arbeidsongeschikhoidspercentuge

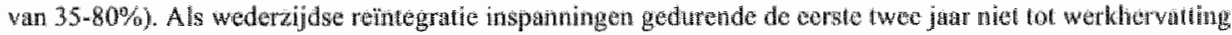
leiden, watt de cerste groep zonder meer terug op de werkloosheidsregelingen, en atanshitend op de bijstand. De weede groep kan in dat gewal echter na afloop wan de werkloosheidsuitkering atmopraak blijwen makern op een uitkering wan $70 \%$ van het minimumloon. Zij krijgen dus niet met de middelentoets van de bijstundsregelingen te maken. Verder geldt woor deze groep dat; als ze well asn het werk konen muar minder verdienen dan $70 \%$ van het wroeggere loon, de werkgever het loon na twee jaar moet aanwullen toi $70 \%$ eth daarvoor verplicht een particuliere werzekering moet afsluten. De eerste twee jaar wan bet reintegratieproces moet de werkgewer op grond wan art. $7.629 \mathrm{BW} 70 \%$ wat het loon doorbetalen. De loonbeialingsplicht bij zickte wordt aldus met een jaar werlengd. Gechurende hei wweede jaar mag deze $70 \%$ niel op grond wan cao afspraken worden arangevuld tot $100 \%$. Aandyenomen word dat de werknemet zo een extra prikkel zal krijgen om an het werk te gaan. Zie woor deze regeling: SER advies, Worken aun Arbeidsgeschiktheid; voorstellen WAO beleid, van 22 maart 2002 , publicatienummer $02 / 05$.

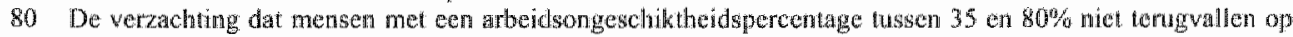
een bijstandsregeling is niet overgenomen. In navolging van de conmissic Donner walt deze categorie, als ze na twe jar niet aan het werk zijn, uiteindelijk terug op een met de $1 \mathrm{OAW}$ vergelijkbare regeling watardoon na verioop van tigd alleen aanspraak op een uitkering kan worden gemaaks als het inkomen van betrokkene en zijn partuer onder de bijstandsnorm uitkornt.

81 Zie daarvoor p. 4 van thet Hoofdlignenakkoord en p. 16 en 17 van de bjjlage bij dit akkoord. 
getreden Wet Verbetering Poortwachter dit probleem voor een belangrijk deell zal ondervangen. ${ }^{62}$ Op grond van het voortschrijdend inzicht dat financiele prikkels niet vanzelf het gewenste gedragseffect hebben, heeft die wet de plichten van werkgevers en werknemers om tot een succesvolle werkhervatting te komen, nader geconcretiseerd en verder aangescherpt. Als gevolg hiervan zijn werkgevers sindsdien wettelijk verplicht om ervoor te zorgen dat zieke werknemers weer zo snel mogelijk aan de slag gaan in hun eigen (al dan niet aan hun beperkingen aangepaste) functie of in andere functie in het eigen bedrijf of een heel ander bedrijf: ${ }^{8}$ Om dit te bewerkstelligen moeten werkgevers tijdig daarop toegesneden maatregelen nemen. Veel is mogelijk in dit verband als de maatregelen maar redelijk zijn en leiden tot een snelle terugkeer in het arbeidsproces. Concrete afspraken hierover moeten, in beginsel uiterlijk binnen acht weken na aanvang van het ziekteverzuim, worden vastgelegd in een plan van aanpak. ${ }^{84}$ Het reïntegratieproces moet zo zichtbaar worden en partijen bovendien een basis geven on elkaar op gemaakte afspraken aan te spreken. Voor werknemers wordt dat nog eens extra onderstreept door de wettelijk plicht on mee te werken aan de opstelling en de uitvoering van het plan van aanpak. Verder is expliciet bepaald dat zij gevolg moeten geven aan redelijke reïntegratiebevorderende voorschriften van de werkgever en een passend werkaanbod van de werkgever moeten aanvaarden. ${ }^{85}$

Doell van deze regeling is te bevorderen dat het reintegratieproces snel op gang komt en liefst voor het einde van het eerste ziektejaar succesvol is afgerond. Succesvol wil in dit verband zeggen dat er binnen een jaar een blijvende oplossing wordt gecreëerd zodat er geen beroep op de WAO hoeft te worden gedaan. Nieuwe sancties moeten verzekeren dat werkgevers en werknemers hun verantwoordelijkheid in dit verband ook echt nemen. Die sancties kunnen worden opgelegd aan het einde van het eerste ziektejaar als blijkt dat er onvoldoende inspanningen zijn gepleegd om tot een blijvende oplossing te komen. Dit wordt beoordeeld door het UWV op basis van een reïntegratieverslag dat uiterlijk vijftien weken voor het einde van het eerste ziektejaar moet worden opgemaakt. ${ }^{86} \mathrm{Komt} \mathrm{het} \mathrm{UWV}$ op basis van dit verslag tot de conclusie dat er door toedoen van de werkgever (nog) geen

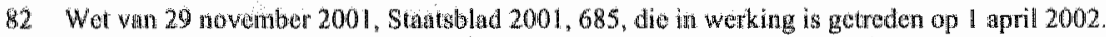

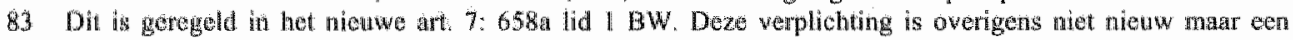
condibatie vath de jurisprudentie rond goed werkgever-en werknemerschap (art: 7; 611 DW) waruit die

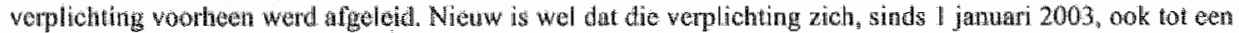

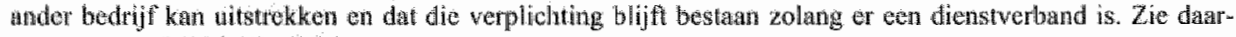
woot ook art. 8 lid 3 Wot RBA.

84 Art. 7: 658a lid 2 BW en ant. Tla lid 2 WAO. Op grond wan de Regeling Procegang Eerste Ztektejaar moet dit plan worden opgesteld als da arbo-karts heen vastgesteld det er sprake us van dreigend langdhrend verzuim, dwa van verzuin dat vermoedeljk langer dan zes weken gaat duren. De arbowienst makt in dat gevall oen problemanalyse en een advies woor eer plan van anpak dat er binnen zes weken na anvang wan het ver-

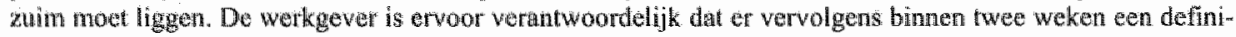
dicl plan van anmogk ligt dat de goedking van zowel de werkgever als de werknemer kan wegdragen. Van deze termijnen kun owerigens worden afgeweken.

85 Art 7:660a BW

86 Art. 7 la lid 3 WAO en art. 3 Regeling Procesgang Eerste Ziektejar. De werkgever moet dit verslag in overteg met de werkneiner opstellen. Het remingratiedossier dat vanaf de zesde week van het verzum moet woiden bijgehouden, dient daarvoor als basis. Hef verslag moet, met een eigen visie van de werknemer, en een onderdeel met medische en arbeidskundige informatie werzorgd door de arbowdienst, door de werknemer worden ingediond bij het UWV tezamen net de aanvraga voor een WAO-aikering (art. 34a WAO). 
blijvende oplossing is bereikt, dan wordt de bal, via verlenging van de loonbetalingsplicht, teruggespeeld naar de werkvloer en blijft de deur naar de WAO gesloten. Afhankelijk van de aard en de ernst van de tekortkoming kan dit betekenen dat de werkgever zich nog maximaal een jaar moet inspannen om tot een succesvolle reïntegratie te komen. ${ }^{87}$ Ligt het aan de werknemer dat er na een jaar nog geen blijvende oplossing is gevonden, dan kan dit, wederom afhankelijk van de aard en de ernst van de tekortkoming, met een tijdelijke of blijvende verlaging of weigering van de WAO-uitkering worden gesanctioneerd. ${ }^{83}$ Anders dan de werkgever, kan de werknemer ook tijdens het eerste jaar met sancties worden geconfronteerd. Weigert de werknemer zonder deugdelijk grond mee te werken aan redelijke reïntegratiebevorderde maatregelen, aan de aanvaarding van een passend werkaanbod of aan de opstelling of uitwoering van het plan van aanpak, dan kan de werkgever namelijk of stoppen met de loonbetaling of een ontslagvergunning aanvragen ${ }^{89}$ Werknemers kunnen zo behoorlijk onder druk worden gezet om actief aan hun reïntegratie mee te werken.

Of op deze manier het beoogde doel kan worden bereikt, valt opnieuw te betwijfelen. Mogelijk is uiteraard dat een verhoogde druk werkgevers en werknemers inderdaad zal aanzetten tot een snelle omzetting van ziekteverzuim in werk zodat een beroep op de WAO achterwege kan blijven. Mogelijk is echter ook dat de dynamiek van dit systeem per saldo leidt tot verstoring van de arbeidsrelatie en zo uiteindelijk, via een voortdurend gesteggel over de vraag of voorstellen tot reìntegratie wel redelijk en/of passend zijn, uitmondt in beeindiging van het dienstverband.

Een ander zwak punt van deze regeling is dat het welslagen daarvan wederom erg afhankelijk is van het sturende effect van financiële prikkels. Vooral het vooruitzicht dat bij onvoldoende inspanning de loonbetalingsplicht kan worden verlengd dan wel loonverlies, ontslag en verlaging of weigering van de WAO-uitkering dreigt, moet immers waarborgen dat werkgevers en werknemers hun reïntegratieverplichtingen serieus nemen. Afgezien van de vraag of dit nu wel de meest effectieve manier is om een succesvolle werkhervatting te bereiken, kan het beoogde effect daarvan ook op een andere manier worden ondermijnd. Willen de sancties het gewenste gedragseffect hebben, dan is daarvoor immers onder meer vereist dat de gepleegde rë̈ntegratie inspanningen toetsbaar zijn. Do manier waarop die inspanningen worden gedocumenteerd is daarbij een essentiele factor. Bij de voorganger van de Poortwachterregeling, het verplichte reïntegratieplan, bleek juist dit een zwak punt te zijn. Werkgevers lapten die verplichting op grote schaal aan hun laars, zodat onvoldoende reïntegratie inspanningen niet of nauwelijks konden worden gesanctioneerd. Of de Poortwachterregeling voldoende kracht heeft om hierin verandering te brengen, is maar de vraag. Doeltreffende instrumenten daarvoor ontbreken immers. Het daaraan verbonden sanctieapparaat dreigt hierdoor, net als voorheen, een tandenloze tijger te worden. Nu dit op

87 Art. 71 alid 9 WAO jo art. 7: 629 lid $11, \mathrm{c}$ BW.

88 Art. 25 jo 28 , gen h W

89 Art 7: 629 6 , den e BW resp. art. 7: 670b lid 3 BW. De werkgever is wij on te kezen welke wan deze lwee sanctes hij het meest opportun vindt. On to voorkomen dat alle gemakkelik nar het ontshgmiddel wordt gegrepen moet het CWI hel UWV inschakelem bij de beoordeling of ex ontslagvergunting zall wortion ver-

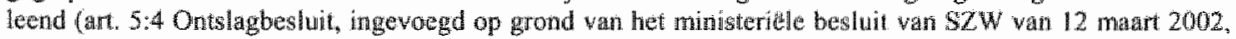
Statscouratit 2002, p. 19$)$. 
basis van ervaringen in het verleden had kunnen worden voorzien, is het toch op zijn minst opmerkelik dat ook op dit punt wordt voortgeborduurd op een oud patroon. Het risico dat het beoogde effect uibliff wordt daamee opnieuw op de koop toegenomen. ${ }^{90}$

\subsection{Onduidelijkheid over controle en reïntegratieverplichtingen}

\subsubsection{Reikwijdte van de informatieplicht}

Verschuiving wan de financiele verantwoordelijkheid voor bestrijding van ziekteverzuim naar het bedriffsleven, brengt ook de andere problemen mee, bijvoorbeeld problemen in de sfeer van de informatewerstrekking. Met het oog op de loonbetalingsplicht bi ziekte en de daaraan verbonden reintegratieverplichtingen, heeft de werkgever er bijvoorbeeld belang bij to weten of de werknemer wel écht zikk is (en hij dus loon moet doorbetalen) en welke beperkingen daturt voortvloeien zodat hij daarop zijn reintegratie activiteiten kan afstemmen. Hiervoor is privacygevoelige, veelal medische informatie nodig, waarover in principe alleen de werknemer en de arbo-arts beschikken. Als de werknemer niet wil dat dit soort informatie bij de werkgever terechtkomt, kan dit de werkgever behoorlijk belemmeren in zijn controle en reintegratie activiteiten. Op zijn beurt kan dit onvrede en allerlei spanningen oproepen alie de arbeidsrelatie gemakkelijk kunnen verstoren.

Om dit te voorkomen is bij de uitbreiding van de loonbetalingsplicht tot het gehele eerste ziektejaar veel impliciet geregeld. De gedachte dat te veel nadruk op de privacybescherming de mogelijkheden om ziekteverzuim snel en adequat aan te pakken zou kunnen frustreren, is hierbij een belangrijke drijfveer geweest. Maar dat heeft well een prijs. Zo heerst er als gevolg daarvan bijvoorbeeld veell onduidelijkheid over de reikwijdte van de rechten en plichten op thet gebied van controle en reïntegratie. ${ }^{91}$ Op grond van de wet heeft de werkgever bijvoorbeeld het recht om controlevoorschriften op te stellen, mits deze redelijk (dat wil zeggen niet onnodig belastend) zijn en slechts betrekking hebben op het verkrijgen van inlichtingen die nodig zijn on het recht op loon te kunnen vaststellen. ${ }^{92}$ Duidelijk is dat die inlichtingen niet zover mogen gan dat de werknemer mededelingen moet doen over de atd van zijn ziekte. Onduidelijk is echter of de verplichting om inlichtingen te verstrekken ook de verplichting onvat om een medisch onderzoek te ondergaan. Duidelijk is slechts dat de werknemer inlichtingen over zijn gezondheidstoestand moet verstrekken an de arts die moet beoordelen of er sprake is van arbeidongeschiktheid.

90 Tekentend in dit verband is da inmiddels al gis gebleken dat in $75 \%$ van de gevallen waran aen reintegraticverslag moest worden opgestuth, dat versag niet deugde of domweg ontbrak. Volgens het UWV werd ith sommige gevallon volstan met en handgeschreven stukje papier waruit wiets op te makern wel: NRC 6 mant $2003, \mathrm{p}, 1.4$.

91 Zie hierover nuder: J.K.M. Gewers, De bedriflsarts en de witwisseling wan medische gegewens bij ziektevertuin, SMA 1996, p. 683-695; J.C.J. Dute, De privatisering van de ZW/WAO en de bescherming van de

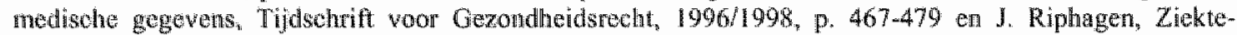
verzuin, controle en privacy, in: Ambeidsredit en Menusbeeld, C.J. Loonstra (red.), Deventer Kluwer 1996 , 1. 61.76

92 Art: $7: 629$ lid $5 \mathrm{BW}$

$93 \mathrm{~T} 1995-1996,24439$, ar, 3, p. 21. 
Voor zijn beslissing om de loonbetaling bij ziekte voort te zetten is de werkgever in hoge mate afhankelijk van de bevindingen van de controlerend arts. Van die arts mag dan ook worden verwacht dat hij de werkgever relevante informatie verschaft. Met het oog op de privacybescherming moet de arts zich daarbij in principe onthouden van mededelingen over de aard van ziekte. In theorie moet hij zich beperken tot de conclusies van zijn bevindingen. Vooral als er onduidelijke klachten in het geding zijn, kan dit bij werkgevers een gevoel van onbehagen veroorzaken. Zij moeten dan afgaan op het oordeel van de arbo-arts, ook als zij er niet van overtuigd zijn dat dit oordeel juist is. Het liefst zouden ze er dan zelf 'boven op" zitten, maar het belang van de werknemer bij bescherming van zijn privacy stat daaratan in de weg. Dit kan een bron van spanning opleveren die de wetgever nu juist wilde voorkomen. In de praktijk kan dit meebrengen dat toch zal worden geprobeerd de gewenste informatie te bemachtigen. De manier waarop de privacybescherming is geregeld biedt daarvoor mogelijkheden. Als puntje bij paaltje komt, is deze regeling namelijk niet water dicht. Met het oog op de reïntegratieverplichtingen van de werkgever mag bijvoorbeeld wel kenbaar worden gemaakt welke functionele beperkingen de werknemer heeft en mag ook een belastbaarheidsprofiel worden overhandigd ${ }^{94}$ In die situatie kan het beroepsgeheim van de arts dus worden doorbroken. Niet uitgesloten is dat privacygevoelige informatie, zoals informatie over de aard van de ziekte, zo via deze omweg toch bekend wordt. De mate waarin de privacy van de werknemer in concrete situaties wordt beschermd, hangt hierdoor in wezen sterk af van de omstandigheden van het geval. ${ }^{95}$

\subsubsection{Reikwijdte van de medewerkingsplicht}

De grenzen zijn nog onduidelijker waar het gaat om de vraag in hoeverre de werknemer aan controle of reïntegratie activiteiten van de werkgever moet meewerken. Dit wordt onder meer veroorzaakt door het feit dat de werkgever dit zo nodig met sancties kan afdwingen, mits zijn activiteiten berusten op 'redelijke" voorschriften en de werknemer geen 'deugdelijke gronden' heeft om medewerking daaraan te weigeren. ${ }^{96}$ Deze formuleringen geven echter weinig houvast wanneer het gaat om de vraag wat in concrete omstandigheden nu precies van de werknemer kan worden verlangd. Afgezien van het feit dat ook dit een bron van spanning en conflicten kan opleveren, is het maar de vraag of deze onduidelijkheid juridisch wel door de beugell kan. Nu de sancties die aan het niet voldoen aan deze verplichting zijn verbonden kunnen meebrengen dat de werknemer zich min of neer gedwongen voelt om privacygevoelige informatie prijs te geven of een onderzoek te ondergaan, valt bijvoorbeeld te betwijfelen of deze regeling de toets van art. 8 EVRM wel kan

94 Art 21 lid 1, W WBP bepall dat de arbo-dienst dit soort gegevers mag verstrekken voorzover dat noodzakelijk is voor de waststeling wan het rech op loon en de temtegratie of begeleiding wan ziche werknomers.

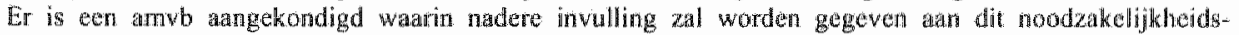
criterium (art. 21 lid 5 WBP).

95 Zie nader over deze problematiek: 1H. Uhlenbroek, Het beroepsgeheim vam de bedrijserts, in Arbatsmech $2003 / 2$, p. 3411 .

96 Zie daarvoor nader art. $7: 629$ lid 6 BW en art. $7: 660$ a cu $7: 670$ b lid 3 b BW. 
doorstaan. Op grond darvan moeten bepalingen die inbreuk naken op de persoonlike levenssteer bijvoobedd woldoende specifiek zijn en dat zijn deze bepalingen niet. ${ }^{\text {gT }}$

Door niet expliciet am te geven wat van betrokkenen op reintegrathegebied mag worden wetlangd, heeft de wetgever sen steek laten vallen. Op grond van de kwaliteitseisen voor wetgeving moet de wetgever immers steeds nagan of zijn producten wel in overeenstemming zijn met grondrehtelike bepalingen, waaronder art. 8 EVRM. By de totstandkoming wan deze regeling heeft de wetgever echter de kool (het privacybelang van de werknemer) wn de geit (de behoefte wan de werkgever aan duidelijkheid) willen sparen en zo voor het bedrijfsleven een werkbare regeling in het leven willen roepen. Door de onduidelijkheid die deze regeling creasert is de wetgever daarin echter niet geslaagd. In plaats van een werkbare regeling is er een regeling tot stand gebracht die juridische mankementen vertoont en bovendion, via allerlei spanningen en conflicten, de arbeidsrelatie behoorlijk kan verstoren. Per saldo ontstaat hierdoor een groter risico op ontslag. De uiteindelijk doelstelling te bevorderen dat mensen waar mogelijk aan het werk blijven en niet hoeven terug te vallen op een uitkering wordt zo op losse schroeven gezet. Ook op dit punt is de totstandgekomen wetgeving dus niet goed doordacht.

\section{$5.8 \quad$ Botsende grondrechien}

\subsubsection{Het recht op privacy versus het recht op een eerlije procesgang}

Het balang van de werknemer bij bescherming van zijn privacy kan ook in een andere situatie botsen met werkgeversbelangen. Door de PEMBA-regeling heeft de werkgever er bijvoorbeeld financied belang bij on te weten of toekenning wan een WAO-uitkering aan een werknemer wel op terechte gronden geschiedt. Is de werkgewer eigen risicodrager, dan kan toekenning van een WAO-uitkering immers betekenen dat de werkgever deze uitkering gedurende vijf jaar aan de werknemer moet witbetalen. Is de werkgever geen eigenrisicodrager, dan kan een dergelijke toekenning tot een verhoogde WAO premie leiden. Gelet op deze financiéle consequenties ligt het in de lijn der verwachting dat de werkgever, bij twijfel aan de juistheid van de toekenningsbeslissing, gebruik zal maken van zijn recht om bezwaar en beroep in te stellen. ${ }^{98}$ Om over de juistheid van de toekenningsbeslissing een

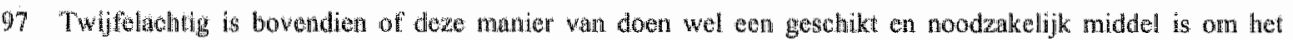
beogde doel (dodtrowferde anpak von het ziekleverzum) le bereiken. Dit hangt sanen met de moodzake-

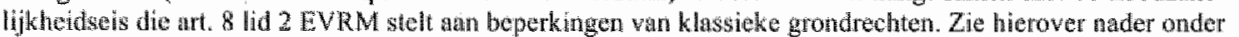
mer: I van dow Helm. Privacy bij priwate en publieke remegratie nadere regulering noodzakelijk voor de priwacybescheming? $S 2003 / 2,13,56$.

98 Van betang herbij is dat bij de invoering van de PEMBA het beperkte belanghebbethe begrip is vervangen door he algenene belanghebbende begrip van ant. 12 Awb. Herdoor geldt voor alle besluiren op grond van do WAO dat devene wens belang rechtstrecks bij cen besluit is betrokken, daartegen betroep kan instelien. De CRvB heef inmiddels uitgemaakt dat de warwargheid van een voldoende, concreet en actueel belang word veronderstield als de werkgever bezwat of beroep instelt tegen een besluit dat eern van zijn werk-

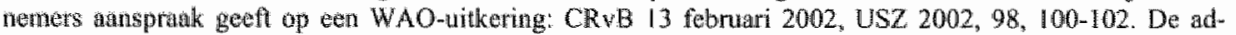
minishutieve rechter heeft hermee gekozen voor en pragmatisch shandpunt. Dit, wellicht vanuit de gedachte dht het woor rectuters ondoenlijk zou zijn on per geval wit woeken of er wel sprake is wan een rechtstreeks betang: Zie hiervoor bijk. BJ van Ettekoven, De medische beshiterregeling in de WAO krakt, Tijdschrin voor Vargoeding van Personensehade, 1999 , p. 59.63 
oordeel te kumen wellen, is echter inzage vereist in alle relevante stukken die aan het toekenningsbesluit ten grondslag hebben gelegen. Nu medische gegevens daarvan een belangrijk onderdeel vormen staat dat echter op gespannen woet met het belang van de werknemer bij bescherming wan zijn privacy. Dit roept de vraag op welk belang in dit soort situaties moet prevaleren: dat van de werkgever op een eerlijk proces of dat van de werknemer op bescherming van zijn persoonlijke levensfeer.

Voor invoering van de PEMBA is deze vraag al aan de rechter voorgelegd. Dit, in verband met de malusregeling, op grond waarvan de werkgever in principe een aantal malen het maandsalaris van de werknemer moest betalen als de werknemer recht kreeg op een WAOuitkering. De CRvB besliste hieromtrent dat bij botsing tussen het recht van de werkgever op een eerlijke procesgang, verankerd in art. 6 EVRM, en het recht van de werknemer op bescherming van zijn persoonlijke levenssfeer, verankerd in art. 8 EVRM, per geval moet worden beoordeeld in hoeverre het privacy belang van de werknemer moet leiden tot witsluiting of beperking van de kennisname van bepaalde stukken door of namens de werkgever. ${ }^{99}$ Omdat dit kan betekenen dat niet kan worden aangetoond dat aan alle voorwaarden voor oplegging van een malus is voldaan, heeft de wetgever besloten de malusregeling af te schaffen. ${ }^{100}$ Maar daarbij is het niet gebleven. De wetgever heeft vervolgens gezocht naar een alternatief en dat alternatief heeft zijn beslag gekregen in de PEMBA-regeling. Qua effect lijkt deze regeling sterk op de malusregeling.Het probleem van botsende grondrechten in een eventuele procedure kwam hiermee weer in volle omvang op tafel te liggen.

\subsubsection{De medische besluitenregeling}

De wetgever heeft dit probleem onderkend en als oplossing hiervoor een speciale procedure in het leven geroepen voor bezwaar en beroepszaken waarin een medische beoordeling in thet geding is: de medische besluitenregeling. ${ }^{101}$ In de kern komt deze regeling hierop neer dat de werkgever alleen medische stukken mag inzien als de werknemer daarin schriftelijk toestemt. Ontbreekt die toestemming of wordt die ingetrokken dan mogen medische gegevens slechts worden verstrekt aan een gemachtigde van de werkgever die arts is. De advocaat van de werkgever mag die stukken dus niet inzien. Voor deze regeling is bewust gekozen ter bescherming van de privacy van de werknemer. Een advocaat beschikt namelijk in de regel niet over de vereiste medische deskundigheid en bovendien is zijn beroepsgeheim van een andere orde dan het beroepsgeheim van een arts. ${ }^{102}$ Deze regeling heeft tot gevolg dat alleen de arts-gemachtigde in de plaats van de werkgever kan treden bij het opstellen van het bezwaar- en beroepschrift en de behandeling daarvan. Zodra het medisch dossier ter zitting wordt besproken, moeten de werkgever en diens advocaat de rechtszaal als gevolg hiervan verlaten; de zitting vindt op dit punt dus met gesloten deuren plaats. Deze regeling heeft verder tot gevolg dat de arts-gemachtigde, op grond van zijn beroepsgeheim, een vergaande zwijgplicht heeft ten opzichte wan de werkgever.

99 CRvB 15 februari $1995, A B 1995,426$ en RSV $1996,214$.

100 Wet Afschaffing Malus en Bevordering Reintegratie, van d. juli 1995, Statsbiad 1995,560 ,

101 Ant. 88-88i WAO.

102 Hiemee werd art. 8: 32 lid $2 \mathrm{Awb}$, dat de vragg of een arts of een advocaal inzage moet krijgen in het medisch dossier overlaat aan de rechter, bewust buiten toepassing gelaten. 
De wetgever heeft gemeend dat het belang van de werkgever bij een eerlije procesgang en het belang wan de werknemer bij bescherming wan zijn privacy op deze manier zo goed mogelijk met elkar zijn verzoend. ${ }^{103}$ Toch rijst de vrag of de wetgever bij de afweging van de belangen die deze grondrechten beogen beschermen wel het juiste evenwicht heeft gevonden. Weliswar waarborgt de medische besluitentegeling, door het recht op inzage uitdrukkelijk voor te behouden an een arts, dat de inbreuk op de prwacy van de werknemer zo beperkt mogelijk blift, mar verhoudingsgewijs is de vraag of deze regeling wet voldoende recht doet aan het werkgeversbelang op een eerlike procesgang er bekaaid afgekomen. Eigenlijk is dat nawwelijks onderzocht.

\subsubsection{Toereikende oplossing?}

Inmiddels is deze onevenwichtigheid ter toetsing aan de rechter voorgelegd In de uitspraken die daarop volgden, heeft de rechter geoordeeld dat de medische besluitenregeling op cen aantal punten niet voldoet aan de elementaire eisen van art. 6 EVRM. Zo kwam de CRVB kort na inwerkingtreding wan de PEMBA al tot de conclusie dat het principe dat de zitting, zodra het medisch dossier op tafel komt, met gesloten deuren plaatsvindt geen recht doet aan het door art. 6 EVRM beschermde recht op een eerlijke procesgang. Dat recht brengt namelijk mee dat partijen in gelijke mate moeten kunnen kennisnemen van de processtukken en ter zitting hun eigen standpunt aan de rechter moeten kunnen voorleggen. Dat kan de werkgever op deze manier echter niet. Hoewel dit niet in overeenstemming is met art. $6 \mathbb{E}$ VRM, verklaarde de CRVB de medische besluitenregeling niet buten toepas sing. In plaats daarvan werd de regeling bijgesteld en wel in die zin dat de rechter voortaan ambtshalve of op verzoek van partijen kan besluiten on de deuren te openen. ${ }^{104}$ of de regeling hiemee volledig in overeenstemming is met art. 6 EVRM blijft echter de vraag. Het EHRM gat namelijk uit van het principe dat de zitting openbaar is, tenzij... In wezen is de uitzondering nu verheven tot regel, zij het daarvan op verzoek van partijen of bij rechterlijk besluit kan worden afgeweken. Wordt deze afwijkingsmogelijkheid niet benut, dan is de zitting gesloten voor éen van de partijen en, daarmee, in strijd met art. 6 EVRM.

Een tweede punt dat ter toetsing aan de rechter is voorgelegd, is of het uitgangpunt dat, als de werknemer inzage in het medisch dossier weigert alleen een arts-gemachtigde dit dossier mag inzien, wal overeind kan blijven. De CRvB oordeelde ook op dit punt dat dit in principe niet het geval is. De werkgever wordt zo immers het recht ontnomen om zijn eigen standpunt in rechte naar voren te (doen) brengen. De arts-gemachtigde treedt namelijk niet op namens, mar in plats van de werkgever. Hij zal daardoor niet altjd het standpunt van werkgever zelf verwoorden, mar eerder zijn eigen standpunt aan de rechter voorleggen. Dat standpunt hoeft echter niet noodzakelijkerwijs te stroken met hetgeen de werkgever zelf in de procedure ter berde zou willen brengen. Hoewel ook deze gang van zaken niet voldoet aan het door art. 6 EVRM gewaarborgde recht op een eerlijke procesgang, verklaarde de CRVB de medische besluitenprocedure ook dit keer niet buiten toepassing. In plaats daarvan koos de CRWB ervoor het geconstateerde gebrek te repareren door toe te

$103 \mathrm{TK} 1995-1996,24698$, nr. 3, p. 30 en 52 en nr. $9,10.105$.

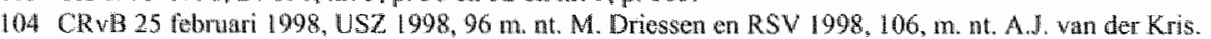


staan dat naast de arts-gemachtigde ook de advocaat van de werkgever kennis kan nemen van de medische stukken, ten minste, als de rechter dat opportaun vindt. ${ }^{105}$ De belangetiafweging bij botsende grondrechten komt 20 bij de rechter te liggen. ${ }^{106}$

Of het geconstateerde knelpunt daarmee voldoende is ondervangen, blift echter de vaag. Als de rechter de adwocat van de werkgever het recht verleent on de medische stukken in te zien, treedt de advocaat immers, net als de arts-gemachtigde, in de plasts van de werkgever. Als de zitting met gesloten deuren plaatsvindt, blift hierdoon het probleem bestaan dat de werkgever zijn eigen standpunt niet in de procedure kan inbrengen wardoor de rechter wellicht geen inzage krijgt in alle voor zijn besluitwonming relevante feiten. ${ }^{107}$ Bovendien brengt de door de CRvB gekozen oplossing mee dat de advocaat cerst in de beroepsprocedure kan worden ingeschakeld. Het door art. 6 EVRM gewarborgde recht op een eerlijke procesgang is namelijk niet van toepassing op de bezwaarfase. ${ }^{108}$ In die fase is het recht on medische stukken in te zien dus nog steeds voorbehouden aan een gemachtigde van de werkgever die arts is. Dit impliceert onder meer dat de beroepsgronden, voor zover die betrekking hebben op medische gegevens, door deze arts zullen worden geformuleerd. De advocaat kan de verdediging pas overnemen als de rechter daartoe in de beroepsfase beslist. De positie van de advocalat wordt er hierdoor niet gemakkeliken op. In principe vormen de door de arts-gemachtigde geformuleerde argumenten, ingebracht in de bezwaarfase, immers de grondslag voor de beroepsprocedure. Of de advocaat deze in de beroepsfase zo nodig nog kan omvormen in meer juridisch getinte argumenten is daarom maar de vraag. Niet uitgesloten is hierdoor dat het recht op een eerlijke procesgang, on danks de rechterlijke reparatie, in concrete situaties toch niet altijd voldoende gewararborgd zai. zijn.

Of de medische besluitenregeling na deze rechterlijke reparatie nog wel in overeenstemming is met art. 8 lid 2 EVRM is eveneens onzeker. Op grond daarvan moet het verstrekken wan medische informatie aan derden immers noodzakelijk zijn om het recht op een earlijke procesgang te waarborgen. Verstrekking van medische gegevens aan een artsgemachtigde is hiermee in overeenstenming, maar of hetzelfde geldt voor een advocaat valt te betwijfelen. De geheimhoudingsplicht van exen advocat is immers van andere orde dan die van een arts. ${ }^{109}$ Op grond van deze haken en ogen lijkt het gerechtvaardigd to concluderen dat de medische besluitenregeling, ondanks de rechterlike reparaties, nog steeds rammelt. Dit had kunnen worden woorkomen als de wetgever bij de totstandkoming

105 CRw 20 juli 2001, USZ 2001, 297-200 m. nt. B. Barentsen; RSV 2001, 205/206 en AB 2001, 252/253 m.nt. F. Pennings.

106 Door uitsluiting van art. 8: 32 lid 2 Abw had de wetgever een dergelijke belangenafweging per gevall, onwille wan de rechtszekertheid, willen voorkomen: TK 1995-1996, 24 698, ar. 3. p. 52

107 Zie hierover nader ook: M.J.A.C. Driessen, Pemba onmogelijk?, SR 2062/11, p. 294.

108 In die fase gelden hierdoor minder vergaande waarborgen dan in de beroepsfase, nnar de reclater vond het niet aian hem on dit onderscheid op te heffen: CRvB 13 februari 2002, USZ 98, 100, 101, m. nt. M. Driessen.

109 Zje hiervoor art. 7 van Aambeweling R. (97) 5 van de Rad wan Europa dic kan worden beschouwd als een nadere uitwerking van de evenredigheidstoets die besloten ligt in art. 8 lid 2 EVRM. Vgl. ook hel standpant van de wetgever die alleen verstrekking van en inzage in medische informatie door de arts-gemachtigde cen proportionele maatregel wond die nodig is om het recht op een eerlijk procesgang te wayrborgen. 
van deze regeling zorgvuldiger was nagegaan of en $z 0$ ja hoe de medische besluttenregeting zich werhoudt tot de elementaire eisen wan art. 6 EVRM. Dat had wellicht in eerder stadium duidelijk kunnen maken dat het vinden van een zeker evenwicht tussen art. 6 en art. 8 EVRM vereist dat steeds per geval een afweging tussen deze beide grondrechten wordt gemakt. Deze regeling had zo aan kwaliteit kunien winnen ten allerlei rechterlike reparaties achteraf overbodig kumen maken.

\section{Recht zonder ruggengraat?}

\subsection{Rol van de kwaliteitseisen voor wetgeving}

De wetgeving die de laatste jaren in het kader van de modernisering van het stelsel van sociale zekerheid is verschenen, stemt niet vrolijk. Die wetgeving is immers nauwelijks effecticf, inconsistent, ondoorzichtig, onnodig complex en op vele punten juridisch ondoordacht. ${ }^{10}$ Dit lijkt erop te wijzen dat de wetgever het niet zo nauw neent met de eisen die aan de kwaliteit van wetgeving worden gesteld. De uitkomsten van het wetgevingsproces Wekken in ieder geval de indruk dat bij diverse wijzigingen wel erg snel is aangenomen dat aan die kwaliteitseisen zou zijn voldaan. Dit, hoewel daarop, gezien het uiteindelijke resultaat; wel het één en ander valt af te dingen. Vooral op het punt van de vereiste doeltreffendheid, de uitvoerbaarheid en handhaafbarheid en de rechmatigheid schiet de totstandgekomen wetgeving tekort. "1" Op zich geeft dit te denken. De kwaliteiteisen voor wetgeving hebben namelijk onder meer tot doel om de kwaliteit van beleidsinstrumentele wetgeving te verbeteren. Volgens de toelichting is er, mede door de snelheid warmee dit soort wetgeving meestal tot stand komt, juist bij beleidsinstrumentele wetgeving een reè gevaar dat die wetgeving niet voldoende wordt doordacht en daardoor leidt tot regelverdichting en een gebrek aan effectiviteit. ${ }^{112}$ Dat nu is precies wat er op het terrein van de sociale zekerheid is gebeurd.

Helemal onverklasbaar is dit overigens niet. Daar war het wetgevingsproces wordt gedomineerd door politieke en beleidsinstrumentele doelstellingen, zoals bij de modemi-

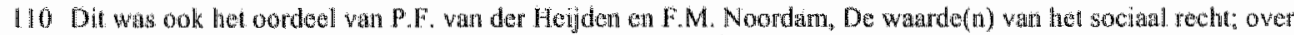

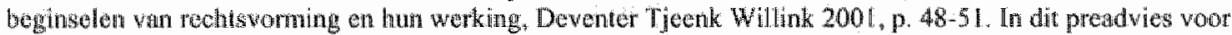
de NJW vorgeleken zij de actiheiten wan te wetgever met en windvan die meedrail thet de politicke wind; au eens dut an dati weer dat.

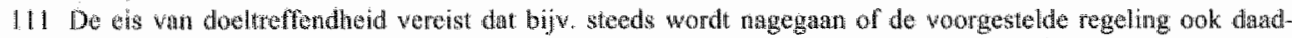

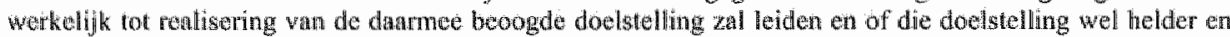

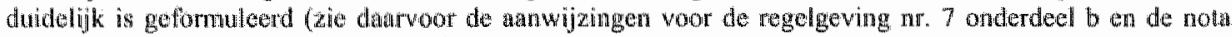

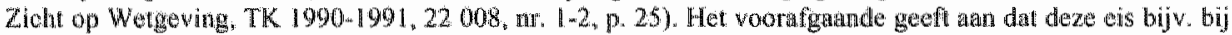

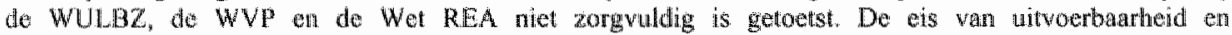
handhantoantheid houdt onder near in dat word onderzoch of de rimte voor interpretatueverschillen en conflicten wel 20 beporkt nogelijk is gehouden (zie darvoor met name de amwijingen voor de regelgeving nr. 11 en 12). Unt het voorafgende blijht dat juist is gekozen yoor vele open normen. De eis van rechimathgeid vereist onder meer dat word onderzoch of de voorgestelde regeling in overeanstenming is met

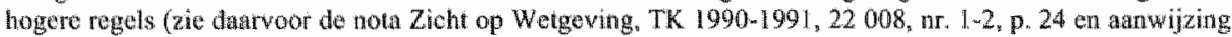
voor do regelgewing ar. 18 ). Par. 5.7 en 5.8 laten zien dat dit niet steeds zorguldig is gebeurd.

112 Nota Zicht op Wetgewing, IK 1990-1991, 22 008, n. 1-2, 16-19. 
seringswetgeving in de sfeer van de sociale zekerheid het geval is, dreigt namelijk het gevaar dat de beoordeling of een bepaalde maatregel aan de kwaliteitseisen voor wetgeving voldoet, wordt gekleurd door die doelstellingen. De mate waarin aan die eisen wordt voldaan wordt zo al snel gewogen in het licht van de bijdrage die een bepaalde maatregel kan leveren aan de verwezenlijking van, in dit geval, overwegend financieet-economische belangen. Andere aspecten dreigen zo onderbelicht te blijven. Dat wordt nog eens versterkt wanneer die doelstellingen een dubbele bodem hebben. Het wordt dan immers wel erg lastig om wast te stellen of de voorgenomen regeling wel zal beantwoorden aan het beoogde doel. Immers, aan welk doel moet dat dan worden getoetst? De gegeven voorbeelden geven aan dat men in $z 0^{\prime} n$ situatie al gauw geneigd is de voorgestelde matregell het voordeel wan de twijfel te gunnen en genoegen te nemen met reparaties om eventuele onbedoelde effecten te ondervangen. ${ }^{113}$

\subsection{Rol var het juridisch kader}

De gegeven voorbeelden laten ook zien dat de juridische grenzen van een bepaalde maatregel vaak niet voldoende worden afgetast. In het krachtenspel dat zich in ieder wetgevingsproces manifesteert, prevaleren politieke en financieel-economische overwegingen veelal boven de puur juridische. Ook dit is niet zo gek. Het juridisch kader dat in het wetgevingsproces in aanmerking moet worden genomen lat de wetgever immers ruime beleidsvrijheid om bij de afwegingen die in dat proces moeten worden gemaakt, prioriteit te geven aan relevante politieke en financieel-economische doelstellingen. Dat het juridisch kader voornamelijk wordt gevormd door sociale grondrechten is hierbij een belangrijke factor. Het feit dat die grondrechten veelal zijn geformuleerd als instructienormen maakt hun rechtskarakter namelijk onduidelijk. Weliswaar is bij de totstandkoming van de herziene Grondwet in 1983 met verve verdedigd dat sociale grondrechten rechtsnormen zijn, maar in werkelijkheid wordt de normatieve betekenis daarvan veelal gebagatelliseerd. ${ }^{1 / 4}$ Tijdens de parlementaire behandeling van de herziene Grondwet is ook aangegeven dat deze rechtsnormen bij de gedachtewisseling in de Staten Generaal in aanmerking moeten worden genomen en dus uitdrukkelijk in de belangenafweging moeten worden betrokken.

113 Zie hierower nader bijv. J.G.A. van Mierlo, De wereld gaat aan beleid ten onder; over beleldsfaten in de publieke sector en wat daaraan te doen, Matatricht Universiture Pers 2000, p. 13-31.

114 Volgens de regering blijkt het rechtskarrakter wan de sociale grondrechten onder meer wit het feit dat opname van dle grondrechten in de grondwet de owertheid verplichi on "zodanige voorzieningen te treffen dai de matschappelijke werkelijkheid zoveel mogelijk in owereenstenning is met hetgeen de sociale grondrechten aan de burger beogen te verzekeren": TK 1975-1976, $13873, \mathrm{nr} .3, \mathrm{p} .7$. Zie over de twijfel over het reclitskarakter bijw. M.C. Burkens, Grondrechten in een nieuwe Grondwet, NJB 1976, p. 701-716. Burkens spreekt in dit verband over "amorfe beleidsdirectieven waarvan de rechtswerking in achomerduister gehuld bliff". Dezelfde schrijwer noemt het voor de relevantie wan de soeiale grondrechten symptomai isch dat daarvan geen enkele sturende werking is uitgegan bij de herejening van het stelsel van sociale zekerheid in 1987: M.C. Burkens, Gegewen de Grondwet, CSW-bundel Deventer Kluwer 1988, p. 56 . Over het rechtskarakter vali sociale grondrechten kan echter ook anders worden gedacht. Zie daarover bijw. H.J.L.M. van de Luytgaarden: Sociale grondrechten in ontwikkeling, "TwO 1989/7, p. 128-132; F. Vlemminx, Het profiel wan de grond. rechten, Zwolle $1998 ;$ G.J. Vonk, Recht als Europeaniserende krachi in de sociale zekerheid, in: Sociale Zekerheid een ander gezichtspunt; toekomstperspectief vanuit vier disciplines, B3rugge Die Keure 2000, p. 233-239 en A.W. Heringa, Sociale Grondrechten, Den Haag 1989 en dezelfute auteur in Sociale Grondrechten in bet EU Handwest woor Fundamentele Reehten, NJCB-bulletin $2000 / 25$, wir. $5.9 .947-959$. 
Door hun globale fommlering komt daarvan in werkelikheid echter vaak weing terecht. ${ }^{15}$ Sociale grondrechten worden hierdoor in de praktijk meestal niet gezien als serieuze rechtsnormen die, behalve door de rechtsregel waarin zij züj gepositiveerd, ook normatieve werking kunnen hebben door hun samenhang met relevante klassieke grondrechten en rechtsbeginselen. Eerder bestaat de neiging on deze grondrechten, ondanks de bedoeling wan de grondwetgever, toch te zien als beleidsdirectieven die nauwelijks enige nomatieve betekenis hebben. Sociale grondrechten worden $z O$ in feite gedegradeerd tot behartigenswardige belangen warvan, al naar gelang de stand van zaken op politiek of social economisch lerrein, gerust kan worden afgeweken.

Zo geinterpreteerd geeft het juridisch kader bij concurrentie met andere beleidsdoelstellingen nauwelijks houvast. In de beleidsrumte die de wetgever heeft, dreigt het feit dat die beleidsruimte niet alleen een politicke en financieel-economische, maar ook een juridische dimensic heef, thierdoor wit het zicht te verdwijnen. Het juridisch kader krijgt zo gemakkelijk het stempel van "recht zonder ruggengraat'. Bovendien is overheidshandelen hierdoor al, snel gelegitimeerd. Zolang politieke en financieel-economischa overwegingen blijven owerheersen, dreigt men in dit kringetje te blijwen ronddraaien. Door de sterke beleidsmatige geladenheid wan de huidige sociale zekerheidswetgeving is het daarom van des te groter belang om na te gaan hoe dit kringetje kan worden doorbroken. Verbetering wan de rechtsvorming op dit terrein is niet alleen noodzakelijk met het oog op de kwaliteit en de effectiviteit van regelgeving in de sfeer van de sociale zekerheid, maar ook om te woorkomen dat het juridisch kader en de daarmee samenhangende uitgangspunten van socialle rechtvaardigheid de speelbal worden van politieke opportuniteit. Hoe kan worden bevorderd dat het juridisch kader meer rellief krijgt en de wetgever de grondwettelikheid van maatregelen die sociale grondrechten raken nadrukkelijker in het wetgevingsproces betrekt, is daarom een nader onderzoek waard.

\section{Ontwikkelingen op Europees terrein}

\subsection{Shumg via een proces van 'open' coördinatie}

Gelet op de hoge priorteit die momenteel aan bevordang van arbeidsparticipatie wordt gegeven, lijken ontwikkelingen op Europees terein op het eerste gezicht een aardig aanknopingspunt to bieden voor verbetering van de rechtsvoming op dit gebied. Bevordering van arbeidsparticipatie is immiddels namelijk ook hoofddoelstelling wan het Europese werkgelegenheidsbeleid. "Via een proces van "open" coördinatie moet deze doelstelling

15 Zio woor de notiwering wan dit onderdeel van thet rechiskarakter: TK 1995-1976, 13 873, 11. 3, p. 6-7. Zie over deze problenatiek nader bijw.: A.W. Heringa, Sociale Grondrechten, Den Haag 1989, p. 74-76, 134- 140 eill $143-145$.

116 De juridsche gnondslag daarwoor werd gelegel door hef Verdmg van Amsterdan dat in mei 1999 in werking trad. Bit dit verdrag werd de bevondering wan een hoog niveau van wenkgelegenheid toegevoegd aan de doelstellingen van de EU (At. 2 en 3 TEU) en werd en aparte Werkgelegenheidstitel in het verdrag opgenomen watrin die doelsteling nader werd geconeretiseerd (Art. 125-130 TEU). De Europese werkgelegenheids. stratgie, die hieruit voortvloeit, werd echter al in gang gezet in 1997, dus rum voordat de juridische grondslag daarwoor, door inwerkingtreding wan het Verdrag van Amsterdam, zijn beslag kreeg. 
nader vorm en inhoud krijgen. Lidstaten committeren zich daarbij op Europees niveau aan bepaalde beleidsdoelstellingen die nader zijn uitgewerkt in 'Employment Guidelines'. Deze Guidelines zijn gebaseerd op vier pijlers, die ieder voor zich beogen bij te dragen aan verhoging van het aantal mensen dat liefst duurzaam deelneemt aan het arbeidsproces. Tegen deze achtergrond richt de eerste pijler zich bijvoorbeeld op voorkoming van langdurige werkloosheid door werkzoekenden, via een baan, een opleiding of andere inzetbaarheidsverhogende maatregelen $z 0$ snel mogelijk een nieuwe start te bieden. ${ }^{117}$ De tweede pijler heeft tot doel meer arbeidsmogelijkheden te creëren door het opzetten van een eigen bedrijf te vergemakkelijken en onvervulde maatschappelijke behoeften om te zetten in reguliere banen. De derde pijler beoogt tegen dezelfde achtergrond de flexibiliteit binnen arbeidsorganisaties te verhogen. Dit, niet alleen door (meer) gebruik te maken van flexibele arbeidspatronen, maar ook door ervoor te zorgen dat werknemers via adequate bijscholingsprogramma's en allerlei trainingsfaciliteiten zo breed en flexibel mogelijk inzetbaar zijn. ${ }^{118}$ De vierde pijler richt zich tot slot op bevordering van de arbeidsparticipatie van vrouwen. In dit verband wordt veel aandacht gevraagd voor verbetering van de mogelijkheden om werk en familieverantwoordelijkheden beter met elkaar te kunnen combineren. ${ }^{1}$

De controle op de implementatie van deze Guidelines in nationaal beleid verloopt primair via een rapportageplicht in de vorm van nationale actieplannen die de Lidstaten jaurlijks aan de Europese Commissie en de Raad van ministers moeten overleggen. Deze instanties beoordelen de gepleegde inspanningen en brengen van hur bevindingen vervolgens verslag uit aan de Europese Raad. Deze Raad trekt hieruit zijn conclusies, die zowel tot bijstelling van de Guidelines kunnen leiden als tot aambevelingen aan het adres van een individuele Lidstaat. Het nationale beleid kan dus ook op deze manier in een bepaalde richting worden bijgestuurd. ${ }^{120}$ Juridisch gezien is de betekenis van deze vorm van sturing gering. Besluit een Lidstaat om geen uitvoering te geven aan de Guidelines of een aan zijn adres gerichte aanbeveling, dan zijn daaraan geen sancties of andere juridische consequenties verbonden. Hoogstens kan via het ingebouwde controlemechanisme, en de daarmee samenhangende onderlinge vergelijking van betaalde resultaten, morele en/of politieke druk worden uitgoefend om de afspraken, waaraan Lidstaten zich op Europees niveatu hebben gecommitteerd, na te komen.

1.7 Bij jeugdwerklozen moet dit gerealiseerd zijn voordat zij zes manden werkloos zinn en bij volwasen binnen

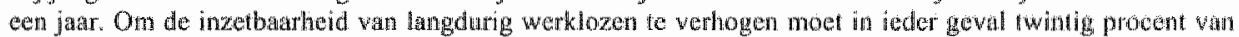

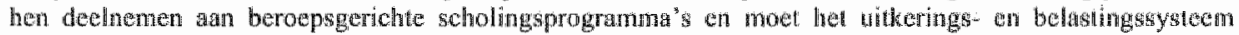

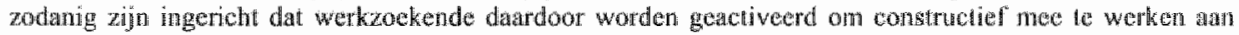
scholingsprogramma"s en actief we zocken naar werk (guidelines 1,2 en 3 ).

118 Lidstaten moeten er met name woor zorgen voor dat degenen dic werken hun konnis ew wardigheden voorturend kunnen opkrikken en verder kumen uitbreiden (lifelong leaning: guideline 6).

119 Verdeeld over deze vive pijlers zijn er inmiddels 18 Guidelines geformulect. Zie daraoor nader: Con (2000), 548 final; Com (2001) 3 13 final en Com (2002), 621 final.

120 Zie voor deze procedure art. 128 TEU. Deze procedure lijk aterk op de procedures die in het kader van lLO. verdragen, hot ESH cr het IVESCR worden gewolgd. Ook dibe procedures zin immers geth op een wappor tageplich, het woeren wan overleg en het doen wan aanbevelingen als overieg nicts oplevert om de naleving van verdragsbepatingen te verzekeren. Woiden verdragsbepalingen geschondin dan wordt dat ook hier niwt juridisch gesanctionecrd, maar word druk uitgeofend en zo dus evenesens gewerbi met cen systeem val "mobilisation of shame". 


\section{2}

Afstemming op het economisch en monetair beleid

De inmiddels behaalde resultaten geven aan dat de Europese werkgelegenheidsbeleid op deze vrijblijwende manier toch een zeker sturend effect heeft. ${ }^{121}$ De beleidsruimte op nationaal niveau word daardoor enigszins ingeperkt. ${ }^{122}$ Daarmee is echter nog niet gezegd dat de rechtsvorming op dit terrein ook zal worden verbeterd. Of en zo ja in hoeverre dat het geval is, hangt in hoge mate af van de inhoud van die doelstellingen. Zeker aanvankelijk was er juist op dit punt reden tot zorg. Bevordering van arbeidsparticipatie werd toen namelijk hoofdzakelijk gezien als middel om het beroep op het sociale zekerheidssysteem te verminderen. Daarop werd sterk gehamerd met het oog op de inmiddels tot stand gekomen Economische en Monetaire Unie (EMU). Budgettaire discipline is een belangrijke voorwaarde on die Unie naar behoren te laten functioneren. ${ }^{123} \mathrm{Om}$ te verzekeren dat Lidstaten zich hieraan houden, zijn er ook op economisch monetair terrein Guidelines tot stand gekomen. ${ }^{124}$ Lidstaten moeten deze Guidelines in acht nemen bij de ontwikkeling van werkgelegenheidbevorderde maatregelen. ${ }^{125}$ Deze expliciete koppeling moet waarborgen dat bij de vormgeving van het werkgelegenheidsbeleid, de begrotingsdiscipline die de EMU oplegt, wordt gerespecteerd. Op deze manier wordt een directe link gelegd tussen werkgelegenheidsbevorderende maatregelen en de eisen van de EMU, die onder meer meebrengen dat eventuele begrotingstekorten de beruchte "drie procent norm" niet mogen overschrijden.

Bevordering van arbeidsparticipatie lijkt in dit licht het ei van Columbus. Immers, naarmate meer mensen deelnemen aan het arbeidproces, zal er minder gebruik worden gemaakt van het sociale zekerheidssysteem waardoor een belangrijke collectieve lastenpost kan worden beperkt. Om dit plan te laten slagen is echter wel vereist dat er meer werkgelegenheid komt. Alleen zo kan immers worden bewerkstelligd dat zoveel mogelijk niet actieven van een baan kunnen worden voorzien. Tegen de achtergrond van de successen die op dit terrein op de Amerikaanse arbeidsmarkt worden geboekt, wordt in dit verband hoog ingezet op flexibilisering van de Europese arbeidsmarkt. Dat moet de motor worden van de Europese banenmachine. Als het Europese systeem maar minder rigide wordt, slaat men bovendien

121 Sind 1997 is het werkgelegentheidsnivean in de EL doegenomen met 10 miljoen banen. De actieve beroeps. botolking growido met 5 miljown mensen en het workoosheidsniveau dalde met 4 miljoen mensen. Z ie: het tapport social Protection in Europe 2001, Brussel 2002, p. 6 on Com (2002), 621 Limal, p. 11. Dit wil niet

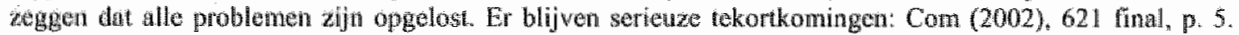
Whe Nedorland betrof, wis wanbovelingen bijwoobeeld herhaldelijk angedrongen op de noodzak on de

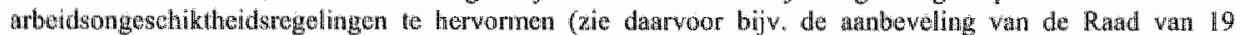

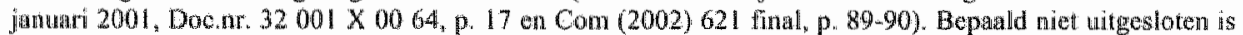
dat deze astobvelingen de druk hebben verhoogd on uiteindelijk an de Advesconmissie Donner de op-

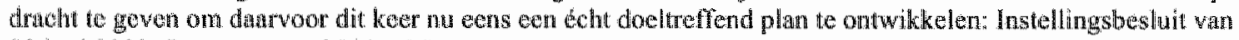
28 juni 2000, Stantscourant 2000,125 .

122 Volghtus art. 128 lid 2 TEU moeten de Lidstaten de Guidelines in aanmerking nemen bij de vormgeving van het inationale werkgelegenheidsbeleid.

123 21 danvoor bijy, de Communicatie van de Europese Commissie, Een werkgelegenhedsagenda woor het jaar $2000, \operatorname{Com}(1997)$, 497 findl.

124 Dit zijn de Broad Economic Policy Guidelnes. Art 99 lid 2 TEU biedt darwoor de juridische basis. De budgettone discipline word verder va het Stabiliteitspet en een antal expliciete wetielike criteria bewakt: zid biju art 116 lid 4 jo art. 104 lid 2 TEU.

125 Dit is thitdrukelujk beparte in art. 126 lid 1 TEU. 
meerdere vliegen in één klap. Een grotere mate van flexibiliteit zal inmers niet alleen meer banen generen, maar ook de economische groei en het concurrentievermogen ten goede. komen, $z o$ is de aanvankelijk gedachte. ${ }^{126}$

\subsection{Doeltreffende aanpak?}

Gaandeweg wordt duidelijk dat deze anpak ook risico's in zich bergt. Zo impliceent overname van het Amerikaanse concept niet automatisch dat daarmee de problemen op de Europese arbeidsmarkten doeltreffend worden aangepakt. Verder kan de combinatie van flexibilisering en budgettaire discipline Lidstaten gemakkelijk aanmoedigen om tot deregulering en terugschroeving van het sociale beschermingsniveau over te gaan om zo binnen de 'drie procent norm' te blijven. De budgettaire normen op Europees gebied geven nationale wetgevers zo dus in wezen een exma impuls om financiael-economische overwegingen in het wetgevingsproces te laten prevaleren. In de loop der tijd wordt ingezien dat dit wel eens schadelijk zou kunnen zijn woor de economische doelstellingen die het succes wan de EMU moeten veilig stellen. Als Lidstaten om budgettaire redenen jeder op hum eigen houtje gaan sleutelen aan het sociale beschermingssysteem, dan kan dat tot witeenlopende oplossingen leiden. De onderlinge concurrentieverhoudingen kunnen zo verstoord raken waardoor de economische stabiliteit die de EMU beoogt te garanderen in gevaar kan worden gebracht. ${ }^{127}$

Ook groeit langzamerhand het besef dat de combinatie van flexibilisering en budgettuire discipline op zich wel neer werk kan generen, maar dat dit nog niet betekent dat meer mensen daardoor duurzaam aan het werk komen of blijven. In werkelijkheid blijkt die combinatie namelijk eerder te resulteren in een toename van het aantal flexibele, "atypische" banen die veelal een tijdelijk karakter hebben en de traditionele vormen van arbeidsbescherming ontberen. ${ }^{128}$ Verder heeft die combinatie tot gevolg dat veel nadruk wordt gelegd op activeringsprogramma's die werkzoekenden via sancties onder druk zetten om iedere kans op werk aan te grijpen. Omdat daarbij meestal weinig rekening wordt gehouden met specifieke persoonlijke capaciteiten en behoeften, leidt dit echter veelal tot kortdurende successen in de sfeer van werkaanvaarding. De uiteindelijke doelstelling on via de terugkeer naar werk het collectiewe lasten niveau binnen de perken te houden wordt daardoor maar mondjesmaat gehaald. ${ }^{129}$ Als gevolg hiervan is de belangstelling voor privatisering van, onder meer, de reintegratiemarkt gegroeid. Op het collecticve lastenniveau heeft dat meestal een gunstig effect, maar een duurzame terugkeer in het arbeidsproces wordt darmee veelal evenmin bereikt. Privatisering van arbeidsbemiddelende an andere hulpverlenende instanties blijkt namelijk gemakkelijk te leiden tot commercialisering van. reintegratieactiviteiten en dat laat zich niet goed rijmen met de intensiteit van de investeringen die nodig zijn om een duurzame terugkeer in het arbeidsproces te bewerkstelligen.

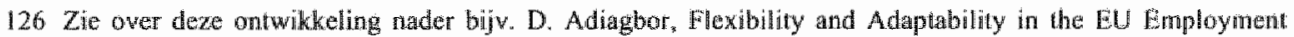
Strategy, in: Legal Regulation of the Employment Rehution, H. Collns, P. Davies and R. Rideout (eds). Deventer Kluwer Intemational 2000 , p. $398-401$.

127 Zie darwoor bijw. Com (1999), 347 final, $3.5-18$.

128 Zie Com (2001), 438 finall, p.5 en 15 an Com (2002) 621 final, p. 20-28.

129 Zie Com (2001), 438 tinal p. 6 en $19 / 20$ en Com (2002) 621 final, p. 6-18 en 31 . 
Een groot deel van de doelgroep staat immers vaak al langdurig buiten het arbeidsproces. ${ }^{130}$ De combinatie vian al deze factoren draagt niet bepaald bij aan het realiseren van de beoogde doelstellingen. Nederland loopt wat dat betreft aardig in de Europese pas. Op Europess niveau heeft deze ontwikkeling inmiddels echter geleid tot bijstelling van de koers.

\subsection{Bijstelling van de koers}

Tijdens de Europese Raad die in maart 2000 in Lissabon werd gehouden, wordt de koerswijziging geconcretiseerd.Sindsdien wordt benadrukt dat de noodzaak om meer werkgelegenheid te creëren niet gepaard mag gaan met aantasting van sociale zekerheden. Deze nieuwe beleidslijn is gebaseerd op het voortschrijdende inzicht dat een sterke economie niet alleen meer banen nodig heeft om een hoger niveau van werkgelegenheid te bereiken, maar ook sociale zekerheden behoeft on een duurzame deelname aan het arbeidsproces te garanderen. ${ }^{131}$ Het is de bedoeling dat deze twee doelstellingen met elkaar worden werenigd zonder de opgelegde budgettaire discipline in gevaar te brengen. Die eis blijft gewoon bestaan. Om aan deze opdracht te kunnen voldoen, worden de Lidstaten opgeroepen om te zoeken naar een nieuw evenwicht tussen flexibiliteit en zekerheid. Concreet betekent dit dat de traditionele systemen van sociale bescherming zodanig moeten hervormd dat die systemen enerzijds er aan bijdragen dat zoveel mogelijk niet actieven aan het werk komen, maar anderzijds ook voldoende werkzekerheid verschaffen zodat zoveel mogelijk mensen duurzaam aan het werk blijven. Om dit te bereiken wordt veel nadruk gelegd op de noodzaak. on meer te investeren in menselijk kapitaal en in verhoging van de arbeidskwaliteit. Verder moet worden verzekerd dat eenieder in gelijke mate toegang heeft tot maatregelen die tot een duurzame arbeidsparticipatie moeten leiden. Meer dan tot dan toe het geval was, moet daarbij rekening worden gehouden met specifieke, persoonlijke behoeften van met name minder bevoorrechte groepen. Bovendien moet, zo nodig, aanspraak kunnen worden gemaakt op begeleiding en andere vormen van ondersteuning die noodzakelijk zijn om een duurzame deelname an het arbeidsproces te realiseren. ${ }^{132}$

Beoogd wordt zo te bewerkstelligen dat blijvend een hoger niveau van arbeidsparticipatie kan worclen bereikt zonder geweld te doen aan de uitgangspunten van sociale rechtvaardigheid warop de systemen van sociale bescherming binnen de EU zijn gefundeerd. In dit

130 Zito damvor bijv. Com (2000), 550 . p. $15 \mathrm{en}$ Com (2002) 621 final, p. $30-31$ en 116 . In Nederland kome het legen deze achergrond voor diat werkzockenden worden verdecld in kavels en vervolgens als vee worden geveild on zo te kumen voldken an een afgesproken percentage te reïntegreren werkzoekenden waaraan private rethtegraticbedrijwen zich ten opzichte van de publicke thitwoenders hebben gecommitteerd: Zie daarover nader ook: P.F. van der Heijden en F.M. Noordam, De warde(n) van het sociaal rech, Deventer Kluwer 2001 , p. 26 en R.J. var der Veen, $L^{2}$ histoire se repete?; honderd jaar uivoeringsorganisatie sociale verzekeringen, in: De Gemeensehap is wansprakelijk... . Den Haag 2001, p. 77-83.

I3. Zie duarvoor bijw. Com (2000), 379. Com (2001), 104 final, p. 4-10. Com (2002) 9 final en Com (2002), 416 finst.

132 Deze lijn werd uitgezet op de Luropese Raad in Lissabon; Com (2000). 349 en is later in verschillende documenten nader uitgewerkt. Zie daarvoo bijp. Com. (2001), 104 final en Com (2001), 3.13 final, (met name p. 11-14 warin een antal indicatoren worden aangegeven om te komen tot verhoging wan de arbeidskwaliteit). Recentelijk is deze koers bevestigd in Com (2002), 62 ॥ final, p. 108-110. 
verband wordt verwezen naar het 'Europese Sociale Model" dat, anders dan het "Amerjkaanse Sociale Model" steunt op een aantal gemeenschappelijke waarden, zouls solidariteit en het streven naar gelijke kansen voor iedereen. ${ }^{133}$ Deze waarden worden daamee in beginsel erkend als intrinsieke waarden die overeind moeten blijen bij het realiseren van economische doelstellingen zoals verhoging van de economische groe, het concurrentievermogen en de flexibiliteit van arbeidsverhoudingen on zo meer werk te creeren. ${ }^{134}$ Naast een primair economisch, moet de EU zo ook een duidelijk sociaal gezicht krijgen.

Op zich is dit een belangrijke ontwikkeling. De bestaande mix van het Europese economisch monetaire en het Europese werkgelegenheidsbeleid is als gevolg daarvan immers bewust met een sociale dimensie verrijkt. Opdat deze sociale dimensie op nationaal niveau niet wordt verwaarloosd, is deze dimensie tevens onderdeel geworden van het proces van "open cö̈rdinatie". In het verlengde hiervan hebben de Lidstaten zich inmiddels ook op dit sociale gebied gecommitteerd aan een aantal belleidsdoelstellingen. Dit geldt onder meer voor de doelstelling om zich in te zetten woor de bevordering van gelijke kansen op maatschappelijke integratie. ${ }^{135}$ Deze doelstelling is niet nader uitgewerkt in officiele 'Guidelines for social inclusion', mar heeft wel geresulteerd in een aantal afspraken op Europees niveau. Net als bij het Europese Werkgelegenheidbeleid moet over de nakoming daarvain regelmatig verantwoording worden afgelegd via nationale actieplannen. ${ }^{136}$ Van belang is hiernaast dat intussen ook twee kaderrichtlijnen zijn angenomen die de doelstelling om gelijke kansen op matschappelijke integratic te realiseren, verder kunnen ondersteunen. Om te bevorderen dat eenieder in gelijke mate toegang heeft tot arbeid, onderwijs en andere dienstverlenende faciliteiten die aan maatschappelijke integratie kunmen bijdragen, voorzien deze richtlijnen in een discriminatieverbod om te voorkomen dat bepaalde minder bevoorrechte groepen van toegang tot deze integratiebevorderende mogelijkheden worden uitgesloten. ${ }^{137}$

133 Zie daarwoor nader bijw. Com (2000), 349 an Com (2001) 104 final, p. 4-ilo.

134 Zie hiervoor de conclusies van de Europese Raad van Lissabon van matart 2000, p. 8-11 en Com (2000) 104 woor ean nadere uitwerking wan deze gedachte. Deze gedachte werd geformulect tegen de achtergrond wan

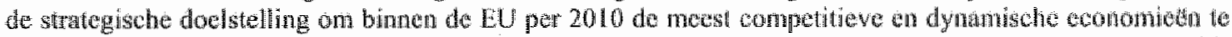
realiseren die duurzame economische groei met meer en betere banen en soeiale colsesie weten to combio neren.

135 Com (2000), 163 fintal. Zle ook: Social Protection in Burope in 2001, Brussels 2002, p. 11 e. . Om het bereiken van deze doelstelling te bevorderen is cen Actieprogramma overeengekomen, om acties op dit terrein te ondersteunen en samenwekking tussen de Lidstaten te bevorderen door uifwisseling van informatio over succesvolle strategiean. Danarwor is 75 miljoen enro beschikbate gesded: Of L 10 van 12 jantari 2002. De Lidstaten thebben zich biemaast geconmitteerd aan de zorg woor ten gegarandeerd inkomen en dat arbeid loont; de zorg voor het zekerstellen en bethalbaar houden van de pensioenstellsels an de zorg voor een duurzame en kwalitatief hoogwaldige gezondheidszorg: Com (2000) 163 final.

136 Tijdens de Europese Raad in Laeken in december 2001 zijn 18 indicatoren wastgesteld aan de hand waarvan Lidstaten de mate van sociale integratic in hon land kumen beoordelen. Op busis datarwan kument wervolgens gerichte matregelen worden genomen. De controle op de implementatio wan gemakte afspraken vindt, anders dan bij het werkgelegenheidsbeleid, on de twee jaar plats. De procedure is dus minder strikt, wat onder meer wordt gerechtwaardigd doordat er woor een proces vam open coordinatie op dif terein gect expliciete juridische basis is Zie hierower nader ook: T. Atkinson, Social hrdicators, the EU and Social Inclusion, Oxford, University Press 2002.

137 Zie daarvoor Richtijn $2000 / 43 / \mathrm{EC}$. Wie ziet op wibanning wan discriminatie op het terrein wan arbeid op grond wan ras of etnische overwegingen, godsdienst of geloot, handicap, leeftijd of seksuele geatardheid en Richtlijn 


\subsection{Howvast voor verbetering wan de rechtsvorming?}

Op het eerste gezicht lijkt deze ontwikkeling consequenties te hebben voor de rechisworming op het terrein van de sociale zekerheid. In principe biedt deze ontwikkeling immers een handvat om het 'sociale tekort' dat door de financiecl-economische krachten van de EMU dreigt te ontstaan, door middel van regelgeving te corrigeren. Van belang hierbij is dat deze nieuwe benadering de beleidsdoelstelling om tot een hoger niveau van arbeidsparticipatie te komen nadrukkelijk met een aantal uitgangspunten van sociale rechtvaardigheid verbindt. De beleidsvorming op dit terrein wordt daardoor in een breder kader geplaatst en kan zich dientengevolge in principe niet langer beperken tot puur formele aspecten wan het al dan niet hebben wan werk. Door de koppeling aan maatschappelijke integratie treedt de materiële betekenis daarvan meer op de voorgrond en zal de beleidsvorming zich dus mede moeten richten op het wegnemen van mogelijke obstakels die aan maatschappelijke integratie in de weg staan. Door de manier waarop hieraan gestalte wordt gegeven te integreren in het proces van "open coördinatie", is dit geen vrijblijvende aangelegenheid. Lidstaten moeten daarover regelmatig verantwoording afleggen. De druk om de genoemde uitgangspunten van sociale rechtvaardigheid nadrukkelijker mee te wegen in de besluitvorming over arbeidsparticipatiebevorderende maatregelen kan daardoor in principe worden verhoogd. Willen die maatregelen voor iedereen in gelijke mate bijdragen aan matschappelijke integratie dan zullen daarbij immers ook aspecten van solidariteit en ongelijkheidscompensatie moeten worden betrokken. Dit perkt de beleidsruimte om bij de totstandkoming van dit soort maatregelen louter financieel-economische gronden te laten prevaleren in beginsel in.

Toch rijst de vraag of dit voldoende is om de kwaliteit van de rechtsvorming op dit terrein op te krikken. De nieuwe benadering berust immers hoofdzakelijk op politieke commitments. Weliswaar bieden de afspraken die op Europees niveau worden gemaakt om die commitments handen en voeten te geven, enig houvast om Lidstaten op nakoming daarvan aan te spreken, maar die kan niet worden afgedwongen. Het zijn sociaall politieke doelstellingen, die bedoeld zijn als aanknopingspunten voor het voeren beleid, maar meestal niet concreet genoeg zijn om daaruit juridisch afdwingbare normen af te leiden. Als puntje bij pualtje komt blijft hierdoor onduidelijk waartoe de bijgestelde koers de Lidstaten nu eigenlijk precies verplicht. Ondanks de aansporing om uitgangspunten van sociale rechtvaardigheid in de besluitvorming te betrekken, blijft de juridische dimensie van die uitgangspunten daardoor schimmig en zal het dientengevolge ook lastig blijven om in het besluitvormingsproces de juridische dimensie van het participatiebeleid duidelijk(er) van de financieel-economische dimensies van dat beleid te onderseheiden. Voor verbetering van de kwaliteit van de rechtsvorming biedt deze nieuwe koers daarom te weinig houvast. Daarvoor zijn namelijk duidelijke aanknopingpunten vereist aan de hand waarvan een juridische vertaalslag kan worden gemaakt, waardoor beleidsvoomemens gemakkelijker op hun

$2000 / 78 / \mathrm{BC}$ die ziet op uitbanning van discriminatie op grond wan was of etnische overwegingen op het terrein van arbeid, onderwijs en de toegang tot goederen et diensten en sociale bescherming. Deze richtijnen zijn gebaseerd op art. 13 TEU. Een Actiephan moet de implementatie dmarvan vergemakkelijken via uitwisseling van informatie en "good practices" die voor de implementatie van de richtlijnen op nationaal nüveau wan belang kunnet zijn: Com (1999), 567 . 
juridische kwaliteit kunnen worden getoetst. Die aanknopingspunten zijn vooralsnog in duistemis gehuld. Dat uitgangspunten vam sociale rechtvaardigheid niet alleen een sociall maatschappelijke, maar ook een juridische grondslag hebben die via hun samenhang met een aantal grondrechten kan worden geconcretiseerd, dreigt zo gemakkelijk over het hoofd te worden gezien. Explicitering van deze samenhang is daarom een belangrijke volgande stap om te komen tot verbetering van de kwaliteit van de rechtsvorming op dit gebied.

\section{Rol van sociale grondrechten bij de modernisering van sociale zekerheïd}

\subsection{Overheidstaak in de sfeer van sociale zekerheid}

Verduidelijking van de juridische dimensie van de uitgangspunten van sociale rechtvaar. digheid die bij de vormgeving van het sociale zekerheidsbeleid in acht genomen moeten worden, begint bij een nadere analyse van de grondwettelijke opdracht om op het terrein van sociale zekerheid regelend op te treden. ${ }^{138}$ Meestal wordt deze opdracht vereenzelvigd met de inkomenswaarborgfunctie van het stelsel van sociale zekerheid. De opdracht om op het terrein van sociale zekerheid regelend op te treden wordt op deze manier beperkt tot het bieden van een zekere inkomensgarantie waarop aanspraak kan worden gemaakt wanneer bepaalde wettelijk gedefinieerde risico's zich manifesteren en het gevaar wan bestaansonzekerheid dreigt. Op zich valt hier weinig tegen in te brengen. Het verschaffen van in komenszekerheid is immers een belangrijk middel om de mens tegen bestaansonzekerheid te beschermen en dat is de 'core business' van de sociale zekerheid.

Toch rijst de vraag of deze taakopvalting van sociale zekerheid in de huidige tijd nog wel toereikend is. De sterke nadruk die tegenwoordig wordt gelegd op de bevordering van arbeidsparticipatie en de eigen verantwoordelijkheid om zelf in het bestaan te voorzien heeft immers een accentverschuiving teweeg gebracht, waardoor andere functies van sociale zekerheid op de voorgrond zijn getreden. De inkomenswaarborgfunctie is hierdoor niet verdwenen, maar het accent ligt toch veel duidelijker dan voorheen op de preventieve, activerende functie van sociale zekerheid. Deze accentverschuiving plaatst de opdracht on op het gebied van sociale zekerheid regelend op te treden in een ander licht. Wil adequaat invulling kunnen worden gegeven aan de verantwoordelijkheid om zelf in het bestaan te voorzien, dan is bijwoorbeeld toegaung tot het arbeidsproces (zodat men zelf een inkomen kan verwerwen), of toegang tot alternatieve beschermingssystemen (zodat daarvoor een redelijk alternatief kan worden gevonden), een belangrijk vereiste. Het behoort in principe tot de verantwoordelijkheid van de overheid om eventuele obstakels die een vrije toegang tot deze "bestaansmiddelen" belemmeren, uit de weg te rumen. De rechtsgrond hiervoor ligt niet alleen in de erkenning van het recht van ieder mens op zelfontplooiing en gelijke kansen als dragende beginselen van de sociale verzekering, maar vloeit ook voort uit de strekking van de sociale grondrechten. ${ }^{139}$ Ook die roepen de overheid immers op om actief

138 Art 20 lid 2 Grondwet.

139 Deze motiwering van de rechtsgrond voor de sociale verzekeringen, zo niet het stelsel van sociale zeketheid als geheel, werd geôntroduceerd door minister Veldkamp bij de invoering van de WAO in 1967. TK 1962 1963 , 7171 , nr. 3, p. 2 en bouwt voort op thet rapport van de commissie Van Rhiyn, waarin werd atangegeven 
op te treden om de bestaanszekerheid resp. de indiwduele en maatschappelike ontplooing van de mens mogelijk te maken. 140 Toegang tot arbeid die zoveel mogelijk recht doet aan persoonlike capaciteiten tesp. toegang tot altematieve beschemingssystemen is daamoor een belangrijke voorwarde.

De overheidstak on de mens tegen bestaansonzekerheid te beschermen krijgt hierdoor een bredere invulling. Zo impliceert het vooropstellen wan de eigen verantwoordelijkheid om zelf in het bestaan te voorzien dat niet langer met verschaffing van inkomenszekerheid kan worden volstaan. On daadwerkelik gestalte te kunnen geven aan die verantwoordelijkheid $z a l$ die bescherming ook vormen van ondersteuning moeten gaan omvatten die de mens in staat stellen om zichzelf in de matschappij te handhaven en zich daarin zo goed mogelijk te ontwikkelen. ${ }^{141}$ De opdracht om op het terrein van de sociale zekerheid regelend op te treden zal zich mede hierop moeten richten. Dit betekent onder meer dat bij de besluitvorming over de te nemen maatregelen op dit gebied, aandacht zal moeten worden besteed aan de vraag of deelname aan het arbeidsproces wel voor eenieder gelijkelijk mogelijk is en bovendien voldoende mogelijkheden biedt om tot individuele en maatschappelijke ontplooing te komen. Dat is niet alleen een logisch complement van de sterke nadruk die tegenwoordig op de preventieve, activerende functie van sociale zekerheid word gelegd, maar sluit ook an bij de geschetste ontwikkelingen op Europees terrein. Ook die ontwikkelingen sporen de Lidstaten immers aan om de vereiste hervorming van hun sociale beschermingssystemen zodanig vorm te geven dat een kwalitatief hoger niveau van arbeidsparticipatie wordt bereikt zonder dat de uitgangspunten van sociale rechtvaardigheid, zoals aspecten van solidariteit en het recht van eenieder op zelfontplooiing en gelijke kansen en bescherming tegen sociale uitsluiting, in het gedrang komen.

dat het een taak van de overheid is erop toe te zien dat iedere burger kan deelnemen aan het mastschappelijk. leven als erkenning wan het recht wan eenieder om door middel wan arbeid in zijn lewensonderhoud te woorzien. Veldkamp onderstreepte dat deatname aun het mastschappelijk leven voor de menselijke ontplooing belangrijker is dan een uitkering, hoewell thet ene niet zonder het andere kan: "hot gaat er in onze mankschappij net al loen om dat mensen lichnumelijk en geestelyk genexen, het gaat erom dat zij een zo volwaardig. mogelijke plaats kuninen innemen in de nusatschappij': EK 1965-1966,7171, nu, $23 a, p .3$. Zie hierover ook: W.J.P.M. Fase, De legitimeting van her werplichtend karakter van de sociale verzekering en F.M. Noordam. Prohthesen en seheerzeep, in: De Gemeenschap is aansprakelijk..., Den Hagg SDU 2001, p. 56 resp. 136.

140 Aanknopingspunten hicevoor zijn bijv. te vinden in: TK 1973-1974, 12.944, 1, p. 307-308 en TK $1975-1976$, 13,873, ar. 3, p. $3,5 / 6$ en ntr. 7, p. 2 en p. 13. Daarin wordt met zoveel woorden gesteld dat de eis dat de zorgpliclii voor woldoende werkgelegenheid mede gericht moet zijn op een rechtwaardige spreiding van de welvant, cok de overheidstak onvat om ervoor te zorgen det eenieder door arbeid in zijn levensonderhoud kan voorzion. Ook word daarin gesteld dat het een fundamentele overheidstaak is on de feitelijke, matatsehappehike en economische belemmeringen die asn de individuele en matschappelijke ontplooing van de unens in de weg stan, weg te nemen. Van belang in dit verband is ook art. 30 van het herriene ESH, dat het recht wan cenieder op bescherming tegen sociale uirsluiting erkent.

141 Zie voor deze vorm van zoketheid bijy. F.X. Kanfmann, Sicherheil alls soziologisches und sozialpolitisches Problem, Stutgant 1970 , p. 396 e.v. Kaufmanns bevindingen hebben in de literatuur weerklank gevonden bij J.J.M. wan der Ven, Sociale Zekerheid, Kwestie wan Denken en Doen, in: Inleiding tot de sociale zekerheid on de toepassing daarvan in Nederland en Belgie. G.M.J. Veldkamp (red.), Deel II: Grondslagen, Deventer 1980, p. 3-14 en bij J. Berghman, De onzichtbare sociale zekerheid, Deventer 1986, p. 10-11. Zie art. 30 ESH voor en concretisering van deze vorm van bescherming. 


\subsection{Concretisering wan de uitgangspunten nan sociale wechtwaardigheid aun de haw van een grondrechtelijk kader}

\subsubsection{Belang van een grondrechtelijke benadering}

Erkenning dat de accentverschuiving op het terrein van sociale zekerheid hand in hand behoort te gaan met verbreding van de overheidstak om op dit terrein regelend op te treden, is echter niet genoeg. Verbetering van de rechtsvorming op dit gebied vereist ook dat de wetgever zich bij de invulling van die taak bewuster oriënteert op het grondrechfelijk kader dat daarbij hoort. Om de brede taakopdracht op het terrein wan sociale zekerheid naar behoren te kunnen uitvoeren, is dat een essentiêle voorwaarde. Sociale grondrechten kunnen hierbij een belangrijk handvat bieden. Die grondrechten bieden namelijk aanknopingspunten aan de hand waarvan de fundamentele waarden waarop de uitgangspunten van sociale rechtvaardigheid steunen, kunnen worden geconcretiseerd en dus zichtbaar kunnen worden gemaakt.

Dit vergt echter wel een grondrechtelijke benadering. Dit impliceert onder meer dat de wetgever bij de besluitvorming over te nemen maatregelen niet alleen op zoek gaat naar relevante sociale grondrechten die deze maatregelen raken, maar daarbij ook rekening houdt met het grondrechtelijk kader waarbinnen die grondrechten zich bewegen. Sociale grondrechten ontlenen hun normatieve werking immers niet alleen aan de concrete bepaling waarin zij zijn verankerd, maar ook aan hun samenhang met relevante klassieke grondrechien en relevante rechtsbeginselen, zoals het gelijkheidsbeginsel, het rechtszekerheidsbeginsel en het evenredigheidsbeginsel. Voor het rechtseffect van sociale grondrechten is juist deze samenhang van belang. Via die samenhang is het namelijk mogelijk sociale grondrechten in verband te brengen met flankerende klassieke grondrechten en rechtsbeginselen die wel rechtseffect hebben. De abstracte instructienormen waarin zij zijn verwoord, krijgen aldus concrete handen en voeten waaruit specifieke verplichtingen voor de overheid kunnen worden afgeleid. Sociale grondrechten krijgen het reliëf dat nodig is om boven het niveau van slechts vage, abstracte normen te kunnen uitstigen. Behalve het rechtskarakter van saciale grondrechten, kan zo ook hun waarde als toetssteen voor de legitimiteit van het gevoerde overheidsbeleid worden verstevigd. Zowel voor de beoordeling van de legitimiteit van het overheidsoptreden op het terrein van de sociale zekerheid, als voor de kwaliteit van de dararuit voortspruitende regelgeving, is dat van groot belang. ${ }^{142}$

Meer concreet betekent dit bijvoorbeeld dat bij de toetsing van de grondwettelijke aspecten van maatregelen die worden genomen om de arbeidsparticipatie te bevorderen, niet kan worden volstaan met het kwalificeren van die maatregelen als een onderdeel van de grondwettelijke zorgplicht voor voldoende werkgelegenheid. Op zichzelf bezien houdt die zorgplicht namelijk niet veel meer in dan een inspanningsplicht om een beleid te ontwikkellen ter bevordering van de werkgelegenheid. Hoe daaraan invulling moet worden gegeven is

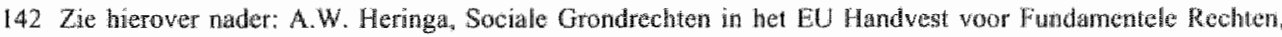

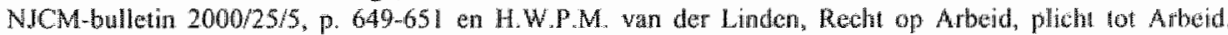
Soctad Recht 1992, p. 303,305. 
niet nader bepaald. Het feitelijk gevoerde beleïd is zo bijna a priori al gelegitimeerd. ${ }^{143}$ Word de zorgplicht voor werkgelegenheíd daarentegen vanuit een breder grondrechtelik kader benader, dan ontstaat een heel ander beeld. By de interpretatie van die zorgplicht heeft de wetgever dan waliswaar nog steeds beleidsvrigheid, maar die vrijheid kan in dat geval worden begrensd door de normatieve werking van andere, met de zorgplicht woor voldoende werkgelegenheid samenhangende grondrechten en rechtsbeginselen evenals door de algemene grondwettelijke strekking om voorwaarden te scheppen om bestaanszekerheid en de individuele en matsehappelijke ontplooing mogelik te maken. De zorgplicht voor voldoende werkgelegenheid wordt zo in een ander perspectief geplaatst. Het bredere grondrechtelijke kader waarin die zorgphicht is ingebed, maakt immers duidelijk dat die zorgplicht niet op zichzelf staat, maar in samenhang met andere relevante grondrechten en rechtsbeginselen en de algemene strekking van sociale grondrechten moet worden beoordeeld en ingevuld. Maatregelen die ter witvoeting hiervan worden genomen, zijin hierdoor niet per definitie geoorloofd, maar zullen aan dit bredere grondrechtelijke kader moeten worden getoetst.

\subsubsection{Betekenis van een grondrechtelijke benadering voor het werkgelegenheidsbeleid}

Voor maatregelen die zijn gericht op verhoging van arbeidsparticipatie, betekent deze benadering dat bij de concrete invulling daarvan rekening zal moeten worden gehouden met aspecten van het recht op arbeid en het gelijkheidsbeginsel. ${ }^{14}$ Daarin liggen namelijk belangrije waarborgen besloten on deelname an het arbeidsproces voor eenieder gelijkelijk mogelijk te maken. Van belang hierbij is dat de overheid op grond van deze rechtsnomen rechtens verplicht is ervoor te zorgen dat eenieder gelijkelijk kan toetreden tot de arbeidsmarkt. $^{145}$ Behalve het garanderen van kosteloze arbeidsbemiddeling brengt deze

1.43 Zie bijw. R, Froque, Het betang van lat recht; ontwikkelingen in de continentale rechtstheorie, in: Recht en Legitimiteit, E.H.E. Bragnans en J.L.M. Elders (red.), Zwolle 1987, p. 35-95; A.J. Hoekema, Legitimiteit

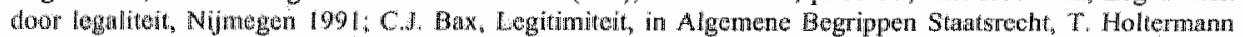

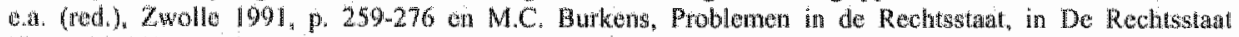
Hurducht, I. W. M. Engels (ned,), Zwolle 19989 , p. 65.71 .

144 Releval in dit verband 2 hin onder meer art. 6 VVESCR en art. 1 ESH resp. ant. 1 Grondwet, art. 2 lid 2

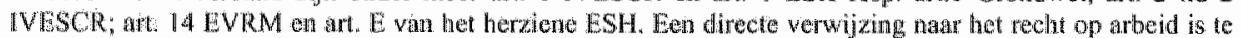
windon in do armof van art. I ESH en art. 6IVESCK, lid 2 van dit artikel verplicht ook tot het nemen van

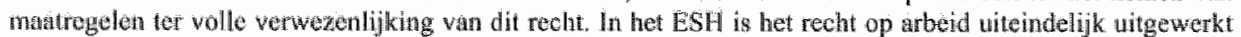

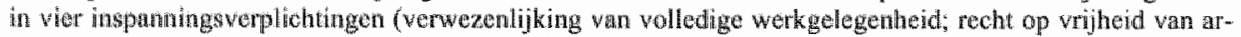
beidskeuke; reht op kosteloze arbeidsheniddeling en zorg voor de bewordering van docimatige beroepskeuzevorliching, vakopleiding on beropswevalidnte . Hat gelikheidsbeginsel kan fungeron als schakel-

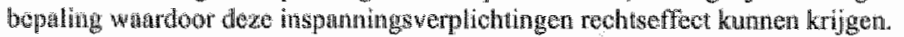

1 45 Voor wat betreft het reoht op anbeid blijkt dat onder meer uit de manier warop do onganen die belast ajn met het towicht op of naloving wan het IVESCR en het ESH het recht op arbeid plegen uit te leggen. Daaruit volgt ondes mer dut er matregelen moeten worden genomen die gericht zijn op het verzekeren van werk

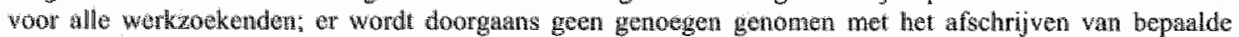
groepen. Zie dannover nader: A.C. Helidriks, Gelijke toegang tor de arbeid voor gehandicapten, Deventer Kluwer 1999, p. 87-89. Voot wat betneft het gelijkheidsbeginsel wolgt dit wit een materiele inhleuring van dat beginusel. Bif de uitleg van art. $26 \mathrm{MBPR}$ gaat het mensenreclitencomite hiervan uit (zie bijv. Ganeral Commont nr. 1837 (1989). Non Discrimination UN OR. Suppl. 40, A/45/40, p. 173-175); hetzelfde geldt voor Het WESCR-comits 2 ie in dit vetband oolo de Standard mules van de VN, die verplichten om barrieres weg to nethen die an do wolwardige deel mame wan gehandicapten aan de samenleving benowiliken (Res. 
verplichting bijvoorbeeld mee dat het werkgelegenheidsbelteid, ten behoeve van groepen met een achterstandspositie op de arbeidsmarkt, 20 nodig wordt gedifferentieend. Meer concreet kan dit betekenen dat een doelgroepenbeleid moet worden gevoend on een bepaalde achterstandspositie weg te werken. Via gerichte scholingsmaatregelen, het in stand houden van gesubsidieerde arbeidsplaatsen of andere specifiek op bepalde achterstandsgroepen afgestemde maatregelen, zoals een doeltreffende bestrijding wan heersende vooroordelen, kan zo worden gewaarborgd dat ook deze groepen gelijke kansen hebben op dee Iname aan het arbeidsproces. ${ }^{146} \mathrm{Op}$ deze manier kan worden bevorderd dat matregelen die in het kader wan de verhoging van arbeidsparticipatie worden ingezet ook daadwerkelijk bijdragen aan de bevordering van maatschappelijke integratie van eenieder, zonder dat de uitgangs:punten van sociale rechtvaardigheid in het gedrang komen.

In dit kader zijn ook interessante ontwikkelingen gaande in de rechtspraak van het Europese Hof voor de Rechten van de Mens (EHRM) ontrent het in art. 8 EVRM verankerde recht op een persoonlijke levenssfeer. Van belang in dit verband is ten eerste dat dit recht zich, in de optiek van het Hof, ook kan uitstrekken tot professionele activiteiten. In dat soort activiteiten liggen volgens het Hof essentielle mogelijkheden om relaties met anderen aan te gaan en dat is, op zijn beurt, een belangrijk aspect van de persoonlike ontwikkeling en, daarmee, van de persoonlijke levensfeer. ${ }^{147}$ Van belang is werder dat het EHRM zich in het kader wan art. 8 EVRM in een aantal zaken op het standpunt heeft gesteld dat rechten die unt dit artikel voortvloeien niet illusoir mogen zijn. Hieruit volgt dat staten gehouden zijn om positieve maatregelen te memen om de uitoefening van die techten daadwerka lijk mogelijk te maken. ${ }^{148}$ Art. 8 EVRM komt hierdoor in beginsel ook in beeld als beoordelingsmaatstaf voor maatregelen die beogen de deelname aan het arbeidsproces te bevorderen c.q. sociale uitsluiting tegen te gaan. ${ }^{149}$ Hieraan zijn echter wel beperkingen verbonden. Uit de rechtspraak van het Hof blijkt namelijk ook dat art. 8 EVRM niet in alle gevallen warin het recht op persoonlijke ontwikkeling op het spel staat, kan worden ingeroepen. Dat kan alleen als er een direct en onmiddellijk verband kan worden aangetoond tussen het in-

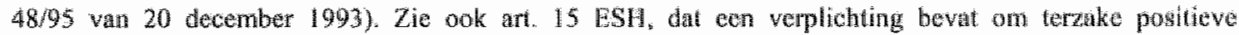

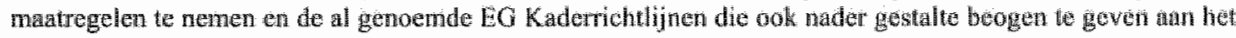
gellijhe kansembeleid.

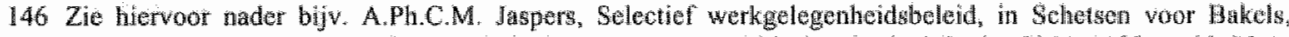
Deventer Kluwer 1986, p. 131-143; E. P. de Jong, Mensbedd in het Socian Recht, SMA 1988, p. 93-95 on

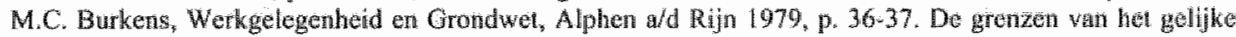

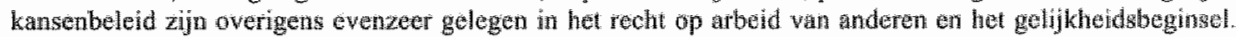
Bewordering wan geljkheid is bijw, allen geoorloofd als het gelije kansenbeld zich richt op het wegnenen

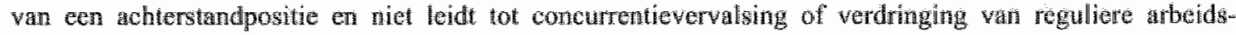
plaxitsen.

147 Zie bij. EHRM inzake Niomietz 1. Duitsland, EHRM 16 decenber 1992, Serve A vol. 251 B. Zic 0ok: EHRM inzake Pnetry t. Werenigd Konmkrijk, EHRM 29 april 2002, nr, 2002/47, warin gen notie vant

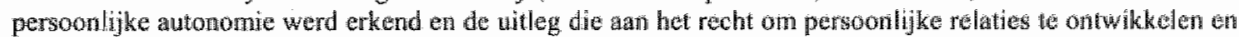
te onderhouden werd samengevat:

148 Zie daarvoor bijv. EHRM inzake Ary t. lerland, EHRM 9 oktober 1979 , Serie A vol, 32 , par. 27 en $X$ en $Y \|$ Nederland, EHRM 26 mart 1985, Serie A vol. 91, par. 21 e.w. Zic hierover ook H. L. Jangsen, Comstiutionele Interpretatie, Den Hatag SDU 2003, p. $361-365 ; 372 \cdot 376$

149 Op die manier zou art. 8 EVRM bijw. kunnen worden gebruikt woor de concretisening van zart 30 van het herziene ESH dat het recht van exweder op bescherming tegen socialle ultsluiting erkent. 
geroepen recht en de gevragde woorziening om dat recht te effectueren. Alleen als ar zo'n directe link is, bestat er met andere woorden een positieve plicht van de staat om actuef op te treder. ${ }^{150}$ Aldus wordt de reikwijdte van art. 8 EVRM en de daaruit voortvloeiende verplichting van de owerheid om positieve maategelen te treffen, beperkt. Dit neemt niet weg dat dit klasieke grondrecht, binnen de gegeven kaders, toch mogelijkheden opent om de opdracht on matschappelijke integratie voor eenieder gelijkelijk mogelijk te maken, nader te specificeren. Binnen de gegeven grenzen kan ook dit voeren tot een concrete verplichting wan de overheid om obstakels die daaraan in bepaalde situaties in de weg statan, te elimineren.

Een grondrechtelijke benadering van het participatiebeleid brengt verder mee dat de wetgever bij de invulling daarwan rekening houdt met het recht op de wrijheid van arbeidskeuze en de algenene grondwettelijke strekking om aan dat beleid vorm te geven op een manier die voldoende rumte laat voor de individuele en maatschappelijke ontolooing. ${ }^{151}$ Deze combinatie stelt bijvoorbeeld beperkingen an de manier waarop de verplichting tot het aanvaarden van passende arbeid en andere reütegratieverplichtingen worden geformuleerd. ${ }^{152} 20$ moet de wetgever bij de formulering van deze verplichtingen en de daaraan verbonden sancties bijwoorbeeld steeds nagaan of het recht op vrijheid van arbeidskeuze daarmee niet wordt uitgehold. Dit impliceert onder meer dat moet worden onderzocht of beperkingen, die bijvoorbeeld via sancties aan dit grondrecht worden gesteld, grondwettelijk gezien wel geoorloofd zijn. De wetgever zal zich in dit verband moeten afvragen of het beoogde doel (bevordering van reintegratie c.q. betaalbaar houden van het stelsel) ook op een andere, minder vergaande manier kan worden bereikt. Is de wetgever van mening dat dit niet het geval is, dan zal moeten gemotiveerd dat afdwinging van de medewerking aan reintegratiebevorderende matregelen door korting of intrekking van de uitkering een geschikt en noodzakelijk middel om reïntegratie te bewerkstelligen. Ook zal moeten worden

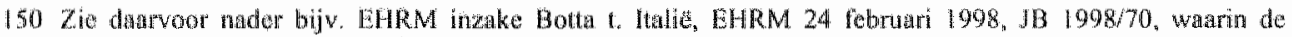

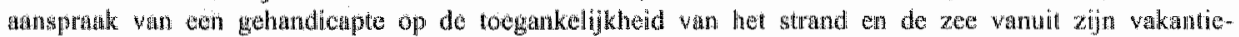

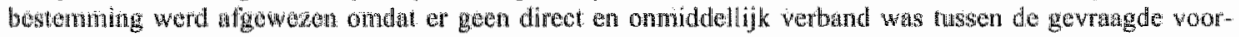

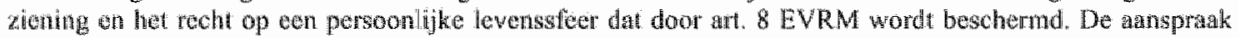
was dasvoor te onbepald en kon dabrom niet worden getoetst anart. 3 EVRM. In IIRM inzake

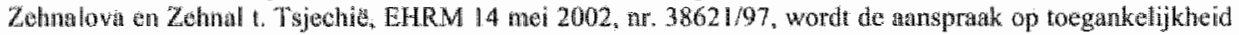
vath openbitu gebowwen eveneens afgewezan. In deze zak enkent het Hof dat art. 8 in geval van een ontoe-

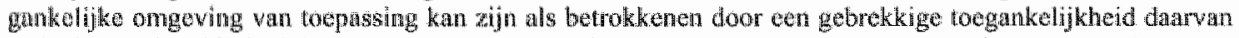
zodanig wordt gehinderd dat het recht op persoonlyke ontwikeling enet recht om relaties met anderen aan to gatan en te onderhowden onder druk komen te stam. Daamee geat het Hof een stap werder dan in de zaak

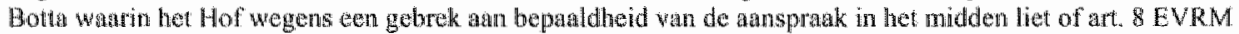

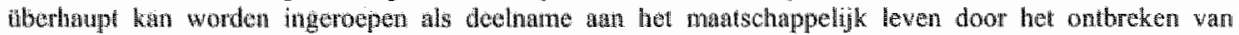

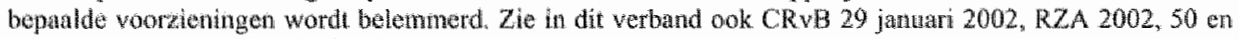
CRYB I oktober 2002, USZ 2002, 326 wamin een beroep op art. 8 LERM onder verwijzing natar Botha eveaeens latde. De erste zak is inmidels ter toetsing voorgelegd aan her EHRM (appl. No. 27677/02).

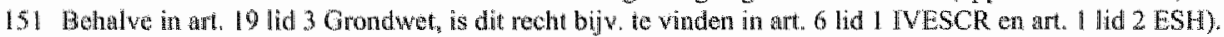

152 Zin in dit verband bijv. A.J.C.M. Geers, Op de grenzen van arbeidsmarktbeleid, grondreaten, arbeidsrecht en sociale zekertieidsrecht: de banenpoo, in Sociaal Recht; de grenzen werkend, Zwolle 1994, p. 77-82. Hij wigt in dit kador ook op art. 10 van 1 LO-verdrag 44 dat beperkingen stell aan de oprekking van het begrip passende arbeid. 
beargumenteerd dat er evenredighed bestaat tussen de inbreuk die met deze maatrgel wordt gentakt op de vrijheid van arbeidskeuze en het doel dat daamee wordt gediend. ${ }^{15}$

Verder zal de wetgever, bij de afwegingen die in dit verband moeten worden gemaakl, ook het gelijkheidsbeginsel in aanmerking moeten nemen. Als de vrijheid van abeidskenze van werkzoekenden wia een strikt sanctiebeleid wordt beperkt, brengt de compenserende werking van het gelijkheidsbeginsel bijvoorbeeld mee dat de vrijheid van waknemerskeuze van werkgevers door maatregelen met een soortgelijk dwingend karakter moet worden ingeperkt. ${ }^{154}$ Omdat dit de bereidheid om bepaalde groepen werkzoekenden in dienst te nemen negatief kan beinvloeden, worden ten aanzien van werkgevers echter veedal maatregelen met een minder dwingend, voorwaardenscheppend karakter geprefereerd. Wil een beleid consistent zijn dan zal de vrijheid van arbeidskeuze van werkzoekenden echter eveneens op een minder dwingende manier moeten beperkt. Wijkt de wetgevar hiervan af, dan zal opnieuw inzichtelijk moeten worden gemaakt welke afwegingen daarbij doorslaggevend zijn geweest. ${ }^{155}$ Ook op deze manier kan een grondwettelijke benadering implicaties hebben voor het te voeren overheidsbeleid. De aan die benadering verbonden motiveringsplicht dwingt de wetgever immers min of meer om gemakte keuzes te verantwoonden. Dit kan ertoe bijdragen dat de bij die keuzes in aammerking te nemen juridische randwoorwaarden bewuster in het besluitvormingsproces worden betrokken. Op zijn beurt kan dit bevorderen dat beter kan worden beoordeeld op welke normatieve uitgangspunten de wetgever het werkgelegenheidsbeleid baseent en of daarbij wel voldoende rekening wordt gehouden met aspecten van sociale rechtvaardigheid die aan die uitgangspunten zijn gelieerd. Per saldo kan dit ertoe leiden dat de kwaliteit en de effectiviteit van het gevoerde beleid en de daarop gebaseerde regelgeving, beter kan worden gewaarborgd.

$₫ 53$ Dit soont vragen hangt samen met het uitgangspunt dat inbreuken op een klasstek grondrecht alleen

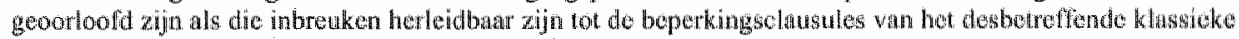
grondrech. Miernit volgt dat beperkingen die bijv. alleon cen algemeen belang dienen, 20 als de

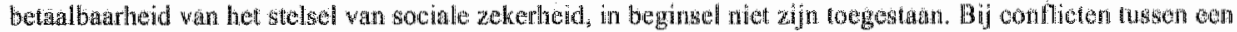

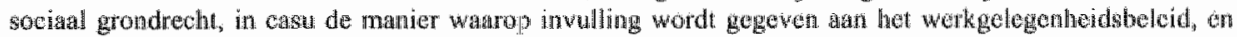

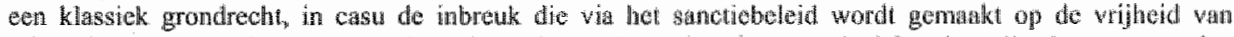

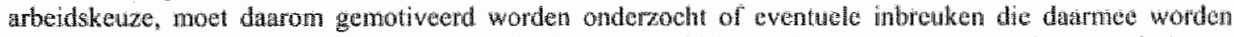

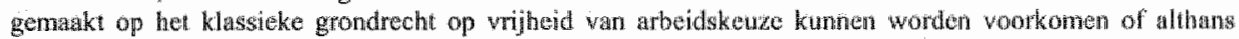

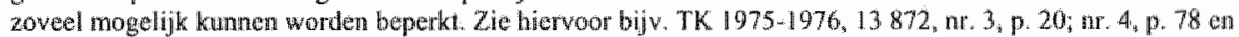
nr. 7, p. $9-12$, D. Pieters, Socule grondrechen op prestaties in de grondweten wan de farden van de

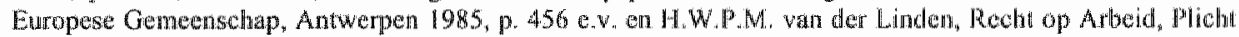
tot Arfeid?, Social Rech $1992 / 1, p .301-305$.

154 Behalve aan en quotumplich (evt. te realigeren via art. 5 Wet REA), kan hubbij bijv, ook worden gedacht san the instrument van contract complianee (warbil de overheid werkgevers beloon met ubbesteding wan contratem als werkgevers bereid zijn bepalde werkzokenden in diensi le mement on an een discriminatieverbod voor bepalde groepen (zie darvoor do a genoemde Europese kaderrichlibne en voor Nederland het daame samerhangende wetsvoorstel inzake getije behandeling op grond van handicap of chronische ziekte: TK, $2001 \cdots 2002,28169$.

155 Zie in dit verbond bijv. I.E. Golluschmidt: Bevordering van arboudskansen van de (overheids)ban?, SMA 1991, p. 59-62 en H.W.M. Wan der Linden, Recht op Arbeid, Plicht to Arbeid, Socian Rech 1992/11, P. $302-305$ 


\section{Tijd voor de volgende stap}

\subsection{Hall werk}

Worden de, onder het mom van bevordering van arbeidsparticipatie, doorgevoerde maatregelen op hun grondrechtelijke merites beoordeeld, dan moet worden vastgesteld dat de wetgever op dit punt niet bepaald consistent te werk is gegaan. Bevordering van arbeidsparticipatie is weliswar verheven tot hoofddoelstelling van het sociale zekerheidsbeleid, maar als het op rechtsvorming aankomt, blijken de daarbij horende fundamentele waarden, zoals het recht wan eenieder op zelfontplooing en gelijke kansen resp. het recht op gelijke toegang tot de arbeidsmarkt en bescherming tegen sociale uitsluiting, al snel uit het oog te worden verloren. Dit blijkt bijvoorbeeld uit het feit dat, voor zover de doorgevoerde maatregelen op hun grondrechtelijke implicaties zijn beoordeeld, die beoordeling vooral betrekking heeft gehad op de inkomenswaarborgfunctie. Daar waar doorgevoerde wijzigingen met aantasting van uitkeringsrechten of verlaging van het uitkeringsniveau gepaard zijn gegaan, heeft de aandacht zich gefixeerd op de vraag of de, in infernationale verdragen verankerde, minimum normen voor de hoogte en duiur van sociale zekerheidsuitkeringen, daardoor niet geschonden zouden worden. ${ }^{156}$ of de wijzigingen ook strookten met de fundamentele waarden die corresponderen met de preventieve, activerende functie van sociale zekerheid is daarentegen veelal in het midden gelaten. In het algemeen is slechts verondersteld dat het met die wijzigingen beoogde arbeidsparticipatieverhogende effect wel zou optreden en dat dit, met een beetje goede wil, ook voor eenieder in gelijke mate het geval zou zijn. De wetgever heeft hiermee half werk geleverd en zo de spanning tussen de financieel-economische noodzaak om het stelsel betaalbaar te houden en de juridische noodzaak om daarbij een gelijke kansenbeleid te voeren en inbreuken op klassieke grondrechten, zoals de vrijheid van arbeidskeuze, zo beperkt mogelijk te houden, wel erg gemakkelijk ten faveure van financieel-economische overwegingen beslecht.

\subsection{Nadruk op rechtsgelijkheid}

Dit wil overigens niet zeggen dat fundamentele sociale waarden in het wetgevingsproces geheel en al buiten beschouwing zijn gebleven.Bij de rechtvaardiging van de genomen besluiten heeft het gelijkheidsbeginsel bijwoorbeeld wel degelijk een voorname rol gespeeld. Dat beginsel is echter primair formeel benaderd. Hierdoor is vooral het streven naar rechtsgelijkheid geaccentueerd: zodra er sprake is van gelijke gevallen, moeten deze in principe ook gelijk worden behandeld. Uit de doorgevoerde wetswijzigingen blijkt dat deze formele benadering een aardige dekmantel kan zijn om bezuinigingen te rechtvaardigen. Zo brengt het principe dat gelijke gevallen gelijk moeten worden behandeld bijvoorbeeld mee dat een nieuw regime, vanaf het moment van inwerkingtreding, in principe voor eenieder gelijkelijk moet gaan gelden. Zowel nieuwe als bestaande gevallen moeten dan dus aan dezelfde

156 Zie biju.: TK 1992-1993, 22 824, nr. 3, p. 70-72 (TBA); TK 1995-1996, 24 439, nr. 3, p. 48-52 (WULBZ) en TK 1994-1995, 24 169, nr. 3, p. 16-20 (ANW). Zie voor dit aspect nader par. 4.2.2. 
rechtsregels worden onderworpen. ${ }^{15 \%}$ Ondat strikte toepassing hiervan, vooral als er bezuinigingen in het geding zijn, behoorlik kan indruisen tegen belanghebbende levende verwachtingen met betrekking tot hun aanspraken $\mathrm{en}_{3}$ daamee, kan botsen met het rechtszekerheids en het vertroumensbeginsel, zijn uitzonderingen op het beginsel van rechtsgelijkheid mogelijk. Deze uitzonderingen kunnen in een overgangsregeling worden neergelegd. Of en 20 ja hoe daaraan wordt vorm gegeven, moet per geval worden beoordeeld. Financieel-economische overwegingen zijn hierbij medebepalend. Een bezuinigingsdoelstelling kan als gevolg hiervan een legitiena reden zijn on van een genereuze overgangsregeling af te zien. Voor het werschil in behandeling dat door eerbiediging van het rechtszekerheidsbeginsel kan ontstaan (bestaande gevallen kunnen dan immers gedurende een lange(re) periode onder het oude, vaak veel gunstiger regime blijwen vallen), bestaat dan, met andere woorden, geen objectieve rechtvaardigingsgrond; het beginsel om gelijke gevallen gelijk te behandelen heeft in die situatie prioriteit. ${ }^{158}$

Met deze interpretatie van het gelijkheidsbeginsel kunnen weliswaar bezuinigingsdoelstellingen worden gediend, maar komen fundamentele waarden die aan de uitgangspunten van sociale rechtvaardigheid zijn gelieerd, tegelijkertijd gemakkelijk in het gedrang. Zoals de reacties op het kersverse plan om bestaande WAO-ers, jonger dan 45 jaar, onder het nieuwe WAO-regime te brengen illustreren, kan dit aanleiding geven to belloorlijke conmotie. De ervaring leert dat dit uiteindelijk tot rechterlijke procedures kan leiden. Er zijn hier namelijk 'eigendomsrechten' in het geding. ${ }^{150}$ Vooral als het rechtszekerheidsbeginsel

157 Dit uitgangspunt van 'onmiddellijke werking' is verankerd in Aawwijzing voor de Regelgeving 166. Volgeng de notite Overgangstecht bij wijzigingen sociale verzekeringswetten geldi dit principe ook voor de sociale

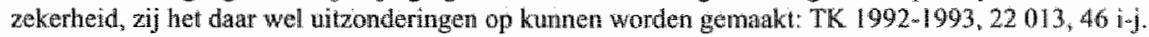

158 Om dit rechivaardigen wordt onder meer een beroep op het solidariteitsbeginsel gedaan: en ruim overgangsrecht zou teveel solidariteit kumen vragen van premiebetalers die zelf genowegen moeten nemen met ninder rechten. Als een rum overgangstecht is gekoppeld aan een wetsvoorstel warmee bezuinigingen moeten

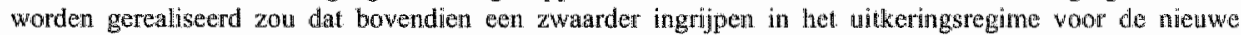
gevallen kunnen betekenen. Zie daarvoor EK 1999-2000, 25900, nr. 87, p. 7 en nr. 87a. Daarin werd ook cen

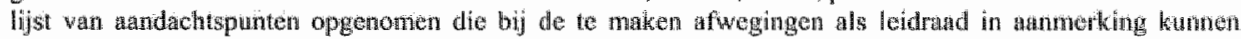

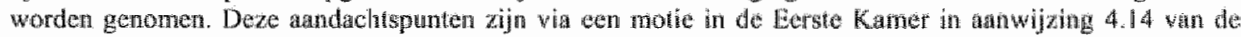

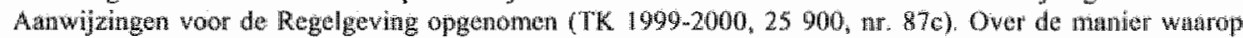

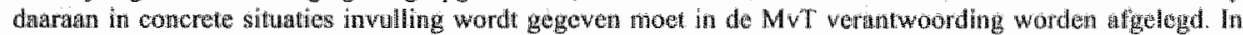
de praktik kan de afweging die moet worden genalakt vot versehillende witkonuten leiden. 20 iss un he

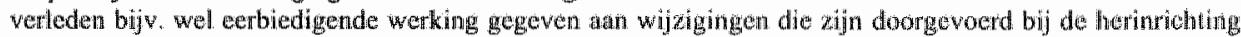
van de Abw, de AOW (samenwonende brows en zussen), de AKW (afschaffing van de kinderbijstug voon personen van 18 jarr en ouder) en gedeetheljk ook atu de wijzigingen die in 1993 werdery angebrath in de

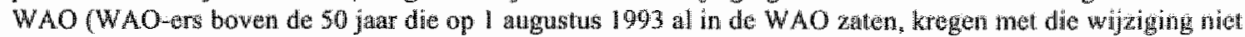

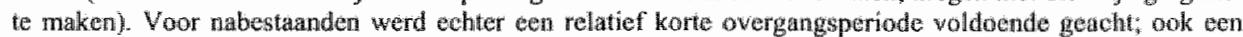

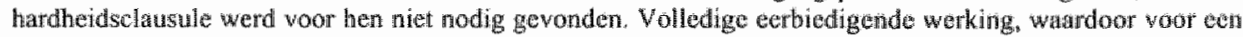

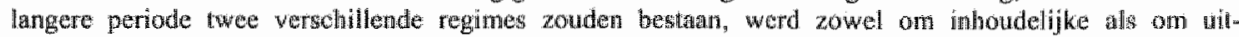
voeringstechnische redenen niet te rechwaardigen noch gewenst geacht: TK 1999.2000, 25 900, nr. 6. p. 16.

159 De arkenning dat socizle zekerheidsrechten onder hef door ait. 1, Eerste protocol EVIRM beswermde

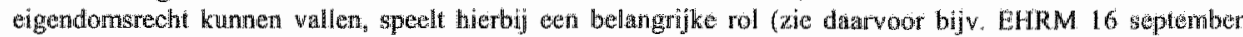

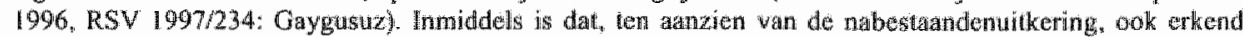
door de CRVB (xie bijw. CRvB 24 jamuari 2001, USZ 2001, 49 en 50). De gedeltelike onthening wan het

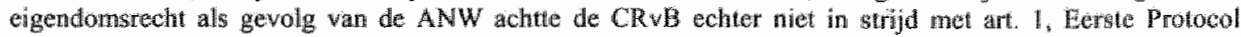
EVRM. Dat artikel eist onder meer dat er en fair balduce is tussen het mei de regeling nagestreefde algemene belang on het ingeroepen eigendomsrecht en dat het middel proporthoneel is in relatio tol liot 
er in het afwegingsprooes bekaaid vanaf komt, bliken belanghebbenden aantastingen van dit soort rechten als een onrechtvaardige aanval op hun bestaanszekerheid te kunnen ervaren. De rechterlijke strohalm moet dan uitkomst bieden. Onbegrijpelijk is dat niet. De aangebrachte wijzigingen in de sociale zekerheidswetgeving werpen betrokkenen immers veelal terug op zichzelf, terwill altematieve beschermingsmogelijkheden, zoals reele toegangsmogelijkheden tot de arbeids- of de particuliere verzekeringsmarkt, soms ontbreken of financieel dan wel om andere redenen niet bereikbaar zijn. Bij een formele benadering van thet gelijkheidsbeginsel is dat ook minder relevant. Het gaat dan namelijk niet zozeer om het bewerkstelligen van gelijke uttkomsten, zoals bij een materielle benadering van het gelijkheidsbeginsel het geval is, maar primair om het scheppen van gelijkheid in rechtspositics en rechtsverhoudingen. Of die gelijkheid wel correspondeert met de werkelijkheid, doet in wezen niet terzake. Als gevolg hiervan is er in principe weinig oog voor de vraag of alternatieve beschermingsmethoden eigenlijk wel reeel toegankelijk zijn. Soms wordt dit ütgangspunt tijdens de parllementaire behandeling bijgesteld, maar soms ook niet. ${ }^{160}$ De ütgangspunten van sociale rechtvaardigheid en de daarmee samenhangende fundamentele juridische waarden worden lierdoor lang niet altijd worden gerespecteerd. ${ }^{161}$ Dat dit niet in overeenstemming is met de overheidstaak om bij het doorschuiven van verantwoordelijkheden ervoor te zorgen dat die verantwoordelijkheden ook echt kunnen worden gedragen, is evident. Door het ontbreken van een duidelijke grondwettelijke loetsing aan de juridische uitgangspunten van sociale rechtvaardigheid, dreigt dit aspect echter onderbelicht te blijven. Uiteindelijk kan dit nopen tot reparaties achteraf die door zo'n grondwettelijke toets woort hadden kumnen worden voorkomen.

beoogde doel. Volgens de rechter was de wetgever bij het afwegen van deze vereisten binnen de gegeven grenzen gebleven. In CRVB 22 december 1999, JB 2000, 31 m.nt. A.W. Heringa, toetste de CRvB de onimeming van de AAW-uitkering aan het eigendomsrecht. De Raad sprak zich daarbij ook uit over de legitimiteil van de schending van dit recht. Bij de beoordeling van de legitimiteitskwestie is, bij ontneming van eigendom, de compensatievraag van belang. De CRvB accepteerde in dit geval een compensatie in de vorm van een overgangsregeling van 26 maander en merkte daarbij op dat bij deze beperkte compensatie awatekening verdien dat bij mastregelen die (mede) zijn ingegeven door dringende tedenen van financiële atud, wen volledlig of zelfs ean ammerkelijke compensatie mict an de orde kan komen zonder de doelstelling wan die matregelen (grotendeels) teniet to doen'.

160 Bij de uibreidling wan de loonbetalingsplicht zijn bijw, wel bewust afspraken met verzekemars gemaakt on te guranderen dat werkgevers hun werknemers, ongeacht hun gezondheddstoestand, tegen een betalbare prijs konden verzekeren (zie par. 5.2). Bij de beperking van de uitkeringsrechten van de WAO in 1993 is een reparatiematregel afgedwongen in de Eerste Kamer, die leidde tot een beperkte aanvullende verzekeringsmogeligheid via een ondorlinge waarborgmaatschappij voor mensen door chronische gezondheidsklachten een verthoogd risico wormen en zich daardoor moeilijk particulier kunnen verzekerta (MAAV). Ten aanzien wan do nabestandenwel is daarentegen uiddrukkelijk opgemerkt dat het aan betrokkenen zelf is on aan hun verantwoordelijkhoid inwulling te geven; de regering zag hier dus woor zichzelf geen actieve, begeleidende vol wergelegd: Handelingen EK, 19 december 1995, p. 14-581.

161 Overigens is dit probleem in de lijst van aandachtspunten in zoverre onderkend dat daarin wordt gesteld dat dimerentintic moet platsvinden als golijke behandeling leidt tot ongerechtvaardigde verschillen tussen groepen. Opgenerkt wordt hierbj dat dan een afweging tussen het gelijkheidsbeginsel en het rechtszekerheidsbeginsel an de onde is; de differentiatie criteria dienen met dit uitgangspunt in overeenstemming te zijn: TK 1999-2000, nr. 87, p. 9-10. Zie in dit verband ook de uitspraak van het Mensenrechten Comite in de zakak Vos, warin het overgangsrech wan de AOW aan de orde was. Uit deze uitspraak blijkt dat de atweging. tussen rechisgelijkheid en reditszekerheid per saldo ook tot strijd nnet thet gelijkheidsbeginsel ex art. 26

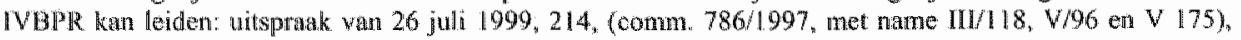
US2, $1999 / 330$. 


\subsection{Oog woor gelike kansew?}

De geschiedenis leert dat het gelikheidsbeginsel ook op een andere manier een rol heeft gespeeld bij wetgeving die in het kader van de hervorming van de socialle zekerheid tot stand is gebracht. Zo is de rechtvaardiging van de wijzigingen die in 1987 en in 1993 in de WAO zijn aangebracht, eveneens voor een belangrijk deel op dat beginsel gebaseerd. Opnieuw is het beginsel van rechtsgelijkheid hierbij de drijvende kracht geweest. Op basis van dat beginsel is het verschil in uitkeringspositie tussen gedeeltelijk arbeidsgeschikte werkzoekenden en "gewone" werkloze werkzoekenden ter discussie gesteld. Ervan witgaande dat beide groepen in beginsel in staat zijn om te werken, is in dit verband benadnukt dat beide groepen in principe in een vergelijkbare positie verkeren als zij er niet in slagen om een baan te bemachtigen. Beide groepen zijn dan in wezen werkloos. Weliswar wordt onderkend dat het werkloosheidsrisico van beide groepen niet volstrekt vergelijkbaar is (zonder aanvullende maatregelen zullen werkgevers inmers eerder geneigd zijn een 'gewone" werkloze in dienst te nemen), maar daar word tegenover gesteld dat ecn verschil in arbeidsmarktpositie geen rechtvaardiging biedt voor het verschil in uitkeringspositie tussen beide groepen. Waarom zou een gedeeltelijk arbeidsgeschikte warkzoekende een betere uitkeringspositie moeten hebben dan een 'gewone' werkzoekende? Ais beide groepen zonder werk zitten, verkeren ze in feite in dezelfde inkomenspositio. Er is dan er geen reden om het daaruit voortvloeiende inkomensverlies op verschillende manieren op te vangen, zo luidt de redenatie. ${ }^{162}$

Op basis van deze redenering is eerst de mogelijkheid om werkloosheid in de arbeidsongeschiktheidsuitkering te verdisconteren, vervallen en is in 1993 de uitkeringsstructutur van de WAO aangepast aan de uitkeringsstructuur van de Werkloosheidswet. ${ }^{6}$ Hoewel deze maatregelen niet hebben geleid tot een volledige gelijkstelling van de uitkeringspositie van gedeeltelijk arbeidsgeschikte en 'gewone' werkzoekenden, is het sindsdien toch minder goed toeven in de WAO. De tijd dat betrokkenen tot hun 65 e vrijwel ongestoord aanspraak kunnen maken op een meestal volledige WAO-uitkering, is daarmee immers voorgoed woorbij. Aangenomen wordt dat deze verslechtering gedeeltelijk arbeidsgeschikten zal

162 TK 1985-1986, 19256, mi. 3, p. 10.15. Zie woor kritick vanul de Kamer op alschaffing wain de verdiscon

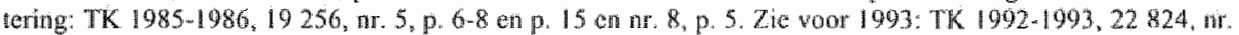

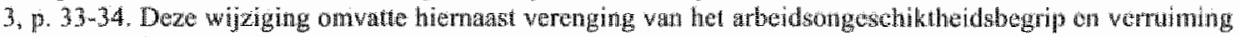
van het begrip passende arbeid (2ie het huidige ard. 18 lid I en 5 WAO).

163 Arschaffing van de werdiscontering leidde to het huidige art. 18 lid 6 WAO. Alg gevolg darvan krigen

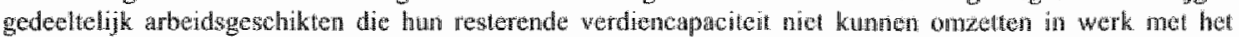
werkloosheidswegime le maken; woor dat deel zijo zij werkloos. Do gelijkstelling wan het nitkenmgregime

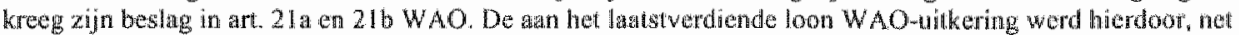
als de WW-uikering. tjdelik ( 2 ij het net door koppeling an en foilehk en fictief abeidsvertedern, nuar door koppeling aan de leeftid op het moment wan arbeidisongegchiki raken). Na afloop van de loon-

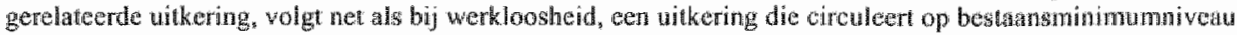

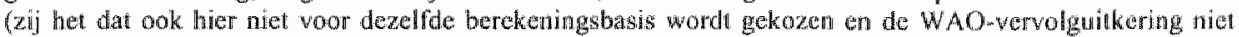
beperkt is in duwr). Bovendien dreigt wor arbeidfongeschikten geen echte bijstand als de anvullende werkloosheidsuitkering afloopt, mant geldr woor thet de IOAW (geen vermogenstoets). Dere regeling is anter afgedwongen. Arbeidsongeschisten blijven dus op bepalde punten beter behandeld dan werklozon. 
prikkelen om er alles aan te doen om weer zo snel mogelijk aan het werk te gaan." De gelijkstelling dient dus ook als prikkel tot bevordering van arbeidsparticipatie.

Op het eerste gezicht lijkt ook bij deze wijzigingen de formele benadering van het gelijkheidsbeginsel te domineren. Mar dat is niet helemaal het geval. De wijigingen worden namelijk geflaikeerd door de, later door de REA vervangen, WAGW. Deze op reintegratiebevordering gerichte regelimgen moet het geconstateerde verschil in arbeidsmarktpositie tussen beide groepen compenseren. ${ }^{165}$ In principe wordt daamee recht gedaan aan de matcriele kant van het gelijkheidsbeginsel. De ondersteunende reintegratiebevorderende matregelen moeten gedeeltelijk arbeidsgeschikten namelijk een extra steunge in de rug geven bij het bemachtigen van een plaats op de arbeidsmarkt. Beoogd wordt zo een eventuele achterstand die zij ten opzichte wan 'gewone' werkzoekenden hebben te egaliseren en aldus gelijke kansen op werk te creëren.

De ervaring leert echter dat de manier waarop dat gebeurt niet doortastend genoeg is. Het pakket ondersteunende maatregelen blijkt in de praktijk te vrijblijvend en te onevenwichtig te zijn om de factoren die de achterstandspositie van gedeeltelijk arbeidsgeschikten un de hand werken, doeltreffend aan te pakken. ${ }^{6 \%}$ Wat zich hier wreekt is het feit dat de juridische uitgangspunten van het gelijke kansen beleid bij de besluitworming over te nemen maatregelen veelal onvoldoende in aanmerking worden genomen. Het gelijke kansenbeleid wordt hierdoor primair gezien als een instrument on het stelsel van sociale zekerheid betaalbaar te houden, waardoor het accent al snel komt te liggen op het kwantiteitsaspect van de terugkeer in het arbeidsproces: hoe meer gedeeltelijk arbeidsgeschikten aan het werk komen, hoe beter. De kwaliteit van de daarbij benodigde ondersteuning dreigt hierdoor niet de aandacht te krijgen die het behoeft, terwijl dat mu juist een belangrijke factor is om een duurzame terugkeer in het arbeidsproces te realiseren. Daarmee kan immers worden bevorderd dat de juiste persoon op de juiste plaats terechtkomt. Op zijn beurt, kan dat voorkomen dat na verloop van kortere of langere tijd weer een beroep op een uitkering moet worden gedaan. Financieel-economische doelstellingen kunnen zo per saldo dichter worden benaderd dan door een beleid waarin de gedachte overheerst dat alle potentiele arbeidskracht, goedschiks of kwaadschiks, moet worden ingezet. De preventieve, activerende functie van sociale zekerheid dreigt dan slechts dienstbaar te worden gemaakt aan doelstellingen van het financieel-economisch beleid, waardoor het belang van het vinden van een balans tussen de noodzaak om het stelsel betaalbaar te houden en de noodzaak om daarbij recht te doen aan een aantal bij die functie behorende fundamentele juridische randvoorwaarden, gemakkelijk uit het zicht verdwijnt. De praktijk leert evenwel dat dit tot

164 TK 1985 1986, 19256, nr. 3, p. 13-14. Zive woon kritiek hierop: TK 1985-1986, 19256, n\%. 5, p. 7. Zie ook TK 1992-1993, 22 824, ni, 3, nr, 6, p, 5 on nr, 10, p. 9: na wagen uit de Kamer geefi het kabinet toe dab er geem harde statistische bewijzen zijn dat versobering wan de uitkeringsrechten zal leiden tot vermindering van hat beroep op de WAO, mar dat er wel con contahe tussen deze twee grootheden bestat. Om die reden was nen anvankelijk ook tegen anvullende verzekeringen voor het WAO-gak: TK 1992-1993, 22 824, nr. $6,16.21$.

165 TK 1985-1986, 19256, nr. 3. p. 15. De WAGW is in 1986 ingevoerd en in 1998 vervangen door de Wet REA.

166 Zie darvoor nacter par. 6.4. 
weinig bevredigende resultaten leidt. Zo wordt in theorie weliswaar een gelijke kansenbeleid gevoerd, maar in werkelijkheid blijkt clat beleid geen échte gelijke kansen te creesen en het bestaande uitsluitingsmechanisme in stand te houden. Als gevolg hiervan wordi veel geînvesteerd in reintegratiebevorderende maatregelen, die als puntje bij paalje komt; niet de daarvan verwachte zoete vmachten afwerpen. Dit leidt vervolgens tot bijstelling van het beleid, waarbij de ene maatregel zich op de andere stapelt. Ondat de grondslag voor het te voeren beleid niet wezenlijk verandert, heeft dit echter geen noemenswaardig effectiviteitsverhogend effect. Alleen de bureaucratie en de complexiteit van het systeem nemen hierdoor verder toe.

\section{Bijstelling van de koers}

\subsection{Verandering van perspectief}

Om deze cirkel te doorbreken is het zaak het werkgelegenheidsbeleid vanuit een andere invalshoek in te kleuren en daarbij meer dan nu het geval is te zoeken nutar een evenwicht tussen de financieel-economische doelstellingen die achter de preventieve, activerende functie van sociale zekerheid schuil gaan en de bij die functie horende juridische randvoorwaarden en uitgangspunten. Een grondrechtelijke benadering geeft daarbij houvast. Die benadering dwingt immers min of meer om in het besluitvormingsproces over te nemen matregelen serieus andacht te besteden aan de vrag of die maatregelen daadwerkelijk zullen bijdragen aan maatschappelijke integratie en of eventuele inbreuken die daarbij worden gemaakt op grondrechten, zoals het recht op vrijheid van arbeidskeuze, grondwettelijk wel geoorloofd zijn. Maatregelen die beogen alle potentiéle arbeidskracht met een strikt sanctiebeleid te stimuleren om iedere kans op werk aan te grijpen (waarop het wetsvoorstel voor een nieuwe bijstandsregeling bijvoorbeeld lijkt aan te sturen), zullen dan al snel afvallen omdat ze te ongenuanceerd zijn om het beoogde doel te bereiken. ${ }^{167}$ Ook de huidige neiging om werkgevers met een opeenstapeling van financiéle prikkels te bewegen. om bepaalde groepen in dienst te nemen of te houden, komt dan in een dubieus licht te staan. Er zijn inmiddels immers bewijzen genoeg dat die prikkels onvoldoende inspelen op de factoren die werkgevers tot (interne of externe) risicoselectie aanzetten en daardoor nict echt bijdragen aam het bevorderen van matschappelijke reintegratie. Het gevaar van sociale uitsluiting wordt hermee dus niet doeltreffend bestreden, terwijl dat nu juist, zowel vanuit

167 Het weivoorstel voor de Wet werk en bijetad legt op alle bijgtandsgerechtigden de plicht om algerneno

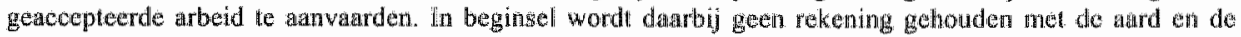
omvang van het werk en de gansluiting bij opleiding of ervaring om het beroep op inkomensondersteuning zo

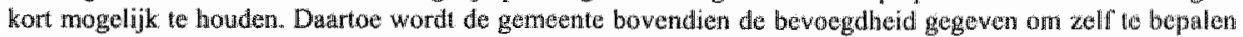
wat de gevolgen zijn voor de uthering buj schending wan deze plicht on zich in te zetten om zo snel mogelifk

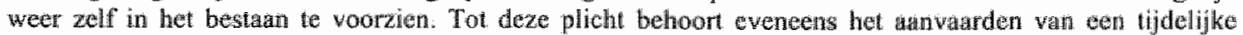

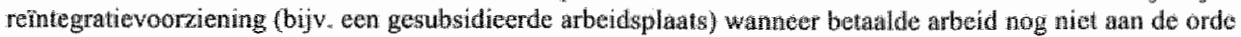

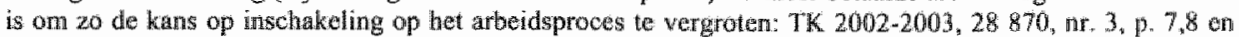
38 resp. art. 8 en 9 wan het wetsoorstel. of op deze manier een durzame matschappelijke integratie kan worden bevonderd is bijzonder wijfelachtig. In combinatie met de vorgenomen $100 \%$ budgettering cen de financiele risico"s die dat voor gemeenten mebrengt, is dit een hachelijke regeling, zeker waner wordt bedach dat bij een omvangrijke groep gemeenten de rechmatigheid van de wionogring nitet voldoende op orde is. Zie daarvoor bijw het jarverslag van de JWI 2002, p. $21-24$. 
cen sociaal maatschappeijk alls vanuit een financieel-economisch oogpunt, cruciaal is. Om het bestaande uitsluitingsmechanisme te doorbreken en maatschappelijke integratie werkelijk te bevorderen is dus een andere anpak vereist. De vraag hoe de activeringsdoelstelling zich eigenlijk verhoudt tot de eisen die tegenwoordig aan deelname aan het arbeidsproces worden gesteld, biedt daarvoor een belangrijk aanknopingspunt. Die vraag kan namelijk leiden tot de conclusie dat deelname aan het arbeidsproces voor bepaalde groepen niet de optimale vorm van maatschappelijke integratie is. In plaats van hierop toch te blijven focussen, kan dan vervolgens naar andere integratievormen worden gezocht, warin deze groepen beter tot hun recht kunnen komen en ook effectiever kunnen functioneren dan in het huidige arbeidsproces. ${ }^{16 x}$ Energie steken in het vinden van methodes om aan deze alternatieve vormen van maatschappelijke integratie invulling te geven op een manier die niet stigmatiserend is en concurrentievervalsing resp. verdringing van reguliere arbeidsplaats voorkomt, is daarom de moeite waard. Dit kan namelijk uitkomsten opleveren die economische en sociale waarden beter met elkaar in evenwicht brengen dan bij het tot nu toe gevoerde beleid het gewal is en, daardoor, per saldo leiden tot effectievere resultaten, zowel in economische als in sociale zin.

\subsection{Betekenis voor de WAO-plannen}

Worden de hervormingsplannen voor de WAO vanuit dit perspectief gezien dan moet worden vastgesteld dat die plannen weinig garantie bieden op daadwerkelijke bevordering van maatschappelijke integratie en daardoor dus niet aan de zojuist genoemde uitgangspunten voldoet. Dit klemt temeer nu deze plannen juist met het doel om sociale uitsluiting tegen te gaan, ingrijpen in de uitkeringspositie van mensen met gezondheidsproblemen. De (op een formele benadering van het gelijkheidsbeginsel gebaseerde) beleidslijn die in de jaren tachlig is ontkiemd, wordt daarmee in wezen verder doorgetrokken. Ook nu is de achterliggende gedachte immers dat mensen die, ondanks medische klachten of beperkingen nog kunnen werken maar geen werk kunnen vinden, als werkloos moeten worden beschouwd.Door afschaffing wan de gedeeltelijke WAO-uitkering is deze groep, anders dan voorheen, in de toekomst echter ook feitelijk aangewezen op een werkloosheids- of een bijstands(achtige)uitkering. Verwacht wordt dat deze ingreep de kans op werk zal vergroten. Enerzijds worden werkzoekenden met gezondheidsproblemen daardoor immers van het stempel 'arbeidsongeschikt' bevrijd en anderzijds wordt aangenomen dat het vooruitzicht van een dreigende overgang naar de werkloosheidsregelingen hen een extra stimulans geven om aan het werk te blijven of te komen.

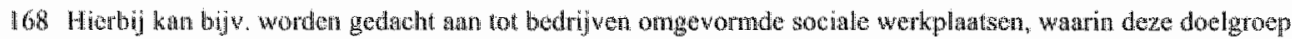
tegen bething in hun eigen tempo of andersins angepaste arbendsomstandigheden wh 20 odig onder begeleiding regulice arbuid kan wemchten, zoals het maken vam meubels of fietsen, of hat uitwoeren wan schitder-, metsol-of tummerwerkzambeden of andere werktantheden in de dienstvarlenende sfeer of de bouw

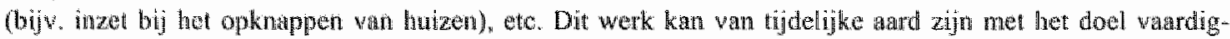

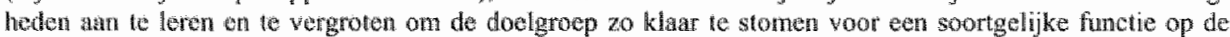
mbeldsmarkt, mat wo nodg ook blijvend wannear deelname wan het arbeidsproces niet de optimale vorm wan natrshappelijke integratie blijt. De Mastrichse MTE geet een aardig voorbeeld van de mante. wanrop an dere alternatiewe vorm wan matschappelijk integratis vorm en inhoud zou kunen worden gegever. Ingezet zou kumen wonden op uitbreiding varn dit soort bedrijven. 
Het aantal arbeidsongeschikten zal door deze matregel zeker verminderen. Maar verwacht mag worden dat het aantal werkzoekende werklozen tegelijkertijd zal stijgen. Of de kans op duurzame deelname aan het arbeidsproces op deze manier zal toenemen, is namelijk zeer de wraag. Gezien de gezondheidsproblemen die hier in het geding zijn, zal daarvoor in de regel meer nodig zijn dan de financiële prikkel die door verandering van etiket ontstaat. Verandering van etiket creëert immers slechts gelijkheid in de nitkeringspositie van werkzoekenden, maar doet verder niets aan doorbreking van het uitsluitingsmechanisme waartegen werkzoekenden met gezondheidsproblemen kunnen aanlopen. Naast een verminderde inzetbaarheid, productieverlies of de noodzaak van intensieve begeleiding, kan ook vrees voor claims op grond van het aansprakelijkheidsrecht hierbij een rol spelen. Verandering van etiket betekent immers niet dat er geen beroep meer op het aansprakelijkheidsrecht kan worden gedaan. Als de oorzaak van de gezondheidsklachten in de werksfeer ligt, neemt de kans dat zal worden geprobeerd om schade langs deze weg te compenseren, juist door de vermindering van uitkeringsrechten, eerder toe. ${ }^{169}$

Het hervormingsplan voor de WAO houdt met deze factoren in feite geen rekening. In plaats van op bevordering van gelijke kansen op deelname aan het arbeidsproces (in materiële zin), concentreert dat plan zich op het realiseren van (formele) gelijkheid in uitkeringsposities, althans voor zover het om werkzoekenden gaat. Voor mensen die door gezondheidsproblemen niet meer in staat zijn om te werken en diurzaam volledig arbeidsongeschikt zijn, blijft een beroep op de WAO mogelijk. Deze groep wordt dus niet met een eventuele overgang naar de werkloosheidsregeling bedreigd en verkeert daardoor, ten opzichte van mensen die ondanks hun gezondheidsproblemen nog well kunnen werken, in een betere uitkeringspositie. Of het onderscheid dat op deze manier tussen mensen met gezondheidsklachten wordt gemaakt juridisch wel door de beugel kan, valt echter te betwijfelen. Het gelijkheidsbeginsel vereist voor rechtwardiging van een onderscheid immers onder meer dat het gemaakte onderscheid op de één of andere manier bijdraagt aan de verwezenlijking van het doel dat daaraan ten grondslag ligt en dat dit doel niet op een andere, minder vergaande manier kan worden bereikt.Zoals uit het voorafgaande al is gebleken, valt dat nu juist zeer te betwijfelen. Doel van het gemaakte onderscheid is

169 Even leek het erop dat er in het verlengde van de herwomingsplannen woor de WAO, planimen werden gesmeed on de mogelijkhoid van compensatie wia het aansprakelijkhe dusrech te werwangen door een op het risque professionnel gebaseerde private verzetering voor arbeidsgebonder schade. De minister wan Sociale Zaken heeft van een dergelijke verzekering, die in wezen neerkomt op cen herintroductie van te 1967 in de WAO getntegreerde Ongevallenwet, echter expliciet afstand genomen. Er is echter wel een onderzoek

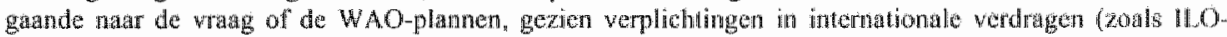
verdrag 128) aanleding geven tot inwoering wan een extra garantieregeting voor bercepsrisico"s om 20 aür international verankerde minimumnormen te kumnen blijven voldoeh (zie daarvoor ook par. 4.2.2). Zie daarvoor de brief van de minister aan de TK van $3 \|$ januari 2003 , kenmerk $03 / 9184$ en Handdingen TK 2002-2003, nr. 40-2942 van 5 februari 2003. Niet wigestoten is achter dat dege internationale toets uiteindeligk toch leidt tot de conclusie dat er een beroepsristcoregeling moet komen. Uit de Belgische rechtspraak kan worden geleerd dat het onderscheid dat darmee wordt geinnoduceerd tursen berospstisico's an andere risico"s op gespannen waet kan staan met het gelljikheidsbeginsel. Zie daaryoor nader het antist vall het Arbitragehof wan 16 januari 1997, nr. 3/97, B.S. 21 januari 1997 en het commentatar daarop in: J. vain Langendonck en J. Put, Handboek voor Sociale Zekertheid, Artwerpen intersentia 2002, p. 333 en 378 -380. In dit licht ligt heroverweging van het hele WAO-plan daram meer voor de hand dan de herintroductio van een beroepsrisicoverzekering. 
immers de kans op werk voor mensen die, ondanks hun gezondheidsproblemen, nog kumen werken, te vergroten door verandering van etket en een daarmee gepaard gaande vermindering wn witkeringstechten. In het voorafgande is al aangegeven dat dit niet afdoende is om her beoogde doel te verwezenlijking. Daarvoor zju andere methodes vereist die zich volop richten op hiet wegnemen van bestaande barrieres en het vinden van adequate oplossingen voor de problemen die deze groep ondervindt bij het vinden of behouden van werk. In par. 10.1 zijn daarvoor suggesties gedaan, die onder meer neerkomen op verbreding van het perspectief door, zo nodig, ook andere vormen wan matschappeljke participatic in de beschouwing te betrekken, ten minste als betrokkenen daardoor beter tot ontplooing kunmen komen en meer productief kunnen zijn dan in het huidige arbeidsproces. Het lijkt niet alleen nuttig, maar ook nodig om het WAO-plan in het licht van dit bredere, grondrechtelijk gerichte perspectief te heroverwegen. Het plan zoals dat er nu ligt, is immers niet alleen aanvechtbaar op grond van het gelijkheidsbeginsel, maar draagt per saldo ook niet bij aat de bevordering van maatschappelijke integratie. Het laat het gevaar van sociale witsluiting eerder in stand en lost daardoor in wezen niets op.

\section{$10.3 \quad$ Slotsom}

De moraal van dit verhaal zal. inmiddels duidelijk zijn: het wordt hoog tijd om het modemiseringsproces warin het stelsel van sociale zekerheid zich momenteel bevindt te schragen met een grondrechtelijke benadering in de hiervoor witeengezette zim. Dat is niet alleen noodzakelijk met het oog op de kwaliteit en de effectiviteit van de regelgeving die aan die modernisering nader gestalte moet geven, maar het is ook een niet meer dan logisch vervolg op de sterke nadruk die tegenwoordig, zowel in Nederland als in Europees verband, op de preventieve, activerende functie van sociale zekerheid wordt gelegd. De moderniseringswetgeving die de laatste jaren tot stand is gebracht, toont overtuigend aan dat die functie niet naar behoren kan worden vervuld zonder de fundamentele juridische randvoorwarden die daarbij horen, bewust in acht te nemen.

Een grondrechtelijke benadering is een cruciale schakel in dit geheel. Juridische randvoorwarden en uitgangspunten kunnen daamee zichtbaar worden gemaakt en bovendien, via hun samenhang met relevante grondrechten en rechtbeginselen, rechtseffect krijgen. Op deze manier wordt duidelijk dat de beleidsvrijheid, die de wetgever bij de hervorming van de sociale zekerheid heef, ook een onmiskenbare juridische dimensie heef, die in het besluitvornirigsproces niet buiten beeld kan blijven. Dit betekent dat te nemen maatregelen nict langer primain in het licht van sociaal economische en politieke omstandigheden kumen worden beoordeeld, maar dat ook verantwoording $z a l$ moeten worden afgelegd over de nanier warop de juridische dimensie en de daarbij horende fundamentele waarden in het beoordelingsproces zijn betrokken. Die waarden krijgen zo niet alleen de betekenis die hen toekomt bij de beoordeling van de legitimiteit van overheidshandelingen, maar kunnen zo ook dienen als toetssteen voor de stelselmatigheid van de rechtwonning en, daarmee, voor de beoordeling of die rechtsvorming well daadwerkelijk leidt tot een (kwalitatief) hoger niveau wan matschappelijke integratie en of daarbij wel voldoende is rekening gehouden met de uitgangspunten van sociale rechtvaardigheid, zoals aspecten van solidariteit en het recht van eenieder op zelfontplooiing, gelikk kansen en bescherming tegen sociale uitsluiting. 
Koudwatervires is hier niet op zijn plats. Een grondrechtelike onderbouwing van veranderingen in de sfeer van de sociale zekerheid is immers in wezen niet meer dan een voor de hand liggende volgende stap op het pad dat in de beleidsvorming al jaren geleden is ingezet. Bovendien is die stap minder drastisch dan het op het eerste gezicht misschien lijk. Er zijn immers al ontwikkelingen gaande die het belang van fundamentele, sociaal grondrechtelijke waarden onderstrepen. Behalve aan ontwikkelingen in de rechtspraak wan het Europese Hof voor de Rechten van de Mens, warin de saciale dimensie van klassieke grondrechten meer en meer wordt verkend en verder wordt ontwikkeld, kan bok de komst van het Handvest voor de Grondrechten van de EU als een exponent wan deze ontwikkeling: worden gezien. Van belang hierbij is, dat veel van de sociale grondrechten watraan de Lidstaten zich in internationale verdiagen hebben gecommitteerd, in dit Handvest zijn ondergebracht. Daammee wordt nog eens extra onderstreept dat Lidstaten die grondrechten moeten respecteren bij de implementatic van Europese regelgeving en Europees beleid, waaronder het Europese Werkgelegenheidsbeleid. De juridische randvoorwaarden en uitgangspunten van dit beleid krigen daarmee ook op deze manier een duidelijker gezicht. Weliswaar heeft dit Handvest nog geen bindende kracht, maat uit uitspraken van het Gerecht wan Eerste Aanleg kan worden afgeleid dat dit Gerecht het Handvest niettemin beschouwt als een document warin rechtsnomen zijn opgenomen die ten grondslag liggen aan de gemeenschappelijke constitutionele tradities van de Lidstaten en op die manier bindend zijn voor de Europese instellingen. ${ }^{170}$ Bovendien ligt het in de lijn van de verwachting dat het Handvest in de nabije toekomst zal worden geîntegreerd in de op handen zijnde Grondwet voor de EU. ${ }^{171}$ Het Handvest krijgt dan langs die weg bindende kracht. Dil kan tot gevolg hebben dat het toezicht op de naleving van de grondrechten die in dat Handvest zijn verankerd een extra impuls krijgt vanuit het Europese niveau, wat Lidstaten kan aansporen om aan daaruit voortvloeiende (positieve) verplichtingen te voldoen. Een grondrechtelijke benadering is als gevolg van deze ontwikkelingen een concept dat langzamerhand wint aan kracht. In dit licht bezien ligt het daarom des te meer voor de hand om hierop in te spelen in het veranderingsproces dat zich momenteel op het terrein van de sociale zekerheid voltrekt. Als de sociale zekerheid dan toch in een moderner jasje moet worden gestoken, is het immers verkieslijk om daarbij dan ook maar meteen te kiezen voor een bijdetjjse grondrechtelijke snit. Een kabinet dat zich ten doel stelt flinke vooruitgang to boeken bij het oplossen van de problemen warmee de samenleving kampt, doet er goed aan hier meteen werk van te maken.

170 Zie bijv. zaak T 54/99, Max. Mobil Telekommumikation Service GmbH t. Commissic, GvEA 30 januari 2002,

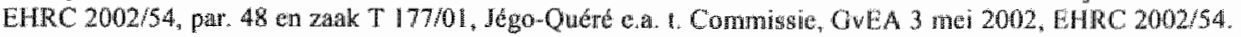
Het Gerecht yan Eerste Aanleg toetst in deze uitspraken aan de algemene beginselen van EG-rech en werhult daarmee dat rechistreeks wordt getoetst an het Handwest. Zie daarvooif J.H. Gerards in de nool bij de cersite witspraak en H.L. Janssen, Constitutionele Interpretatie, Den Haag SDU Uitgevers BV 2003, p. 53.

171 Zie daarvoor art. 5 van het ontwerp voor het toekomstige EU Verdrag watrin de constitutionele stutus yan de EU zijn beslag moet kifigen, Conwentie $528 / 03$, p. 3 en p. 12-13. 



\section{TREMA}

\section{Tijdschrift voor de Rechterlijke Macht}

In Trema worden de ontwikkelingen binnen de rechterlijke nhacht en het procesrecht op de voet gevolgd en vami conmentaar voorzien. Commentar dat nede afkomsitig is uit de gelederen van de rechterlijke macht.

Trema is enerzids het orgaan van de Nederlandse Vereniging voor Rechtsprak, anderzijds het vakblad voon rechters en officieren van justitie én voor iedereen die geinteresseerd is in de ontwikkeling van 'rechitpleging'

Naast artikelen en opinies wordt aandacht besteed aan wetgeving, jurisprudentic, onderzoel over rechrerlijke organisatie, procesrecht en rechterlijk belerd, In een special actued katern worden burgerlijk reeht, strafrecht, bestuursrecht en Europes recht nauw keurig gevolgd Bovendien verschijnen er twee specials per jat.

\section{In Trema vindt u:}

- neuve ontwikkelingen

- achtergrondartikelen

- human interest artikelen

- opinies

- onderzoek

- wetgeving en jurisprudentie

- boekbesprekingen
Trewas werschint 12 maal per yaar (incl. 2 specials)

Daarnalast ontrange is 3 Strathoetnetings bulletirs.

Em abonament kost $\in 101-$ (incl. BTW en do veranelband).

Een los number ontwanger if roos e15,-,

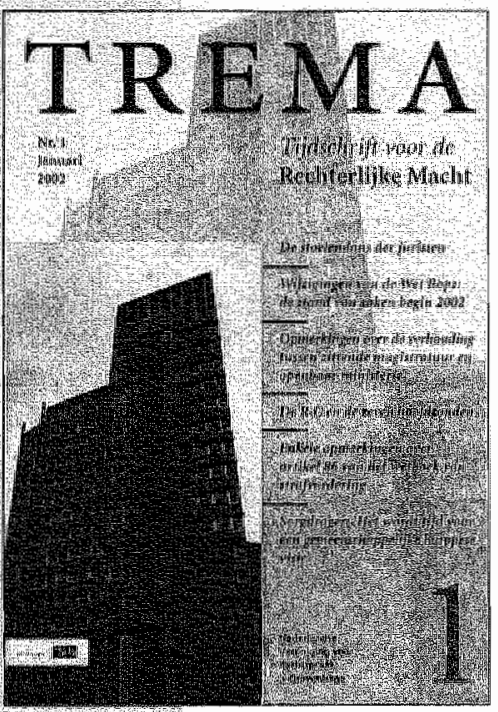

Herniredactie.

Mr. H. M. Horhuis

\section{Redactie:}

nur M. van der Hor prof. nur LU A. Damen. hr E H Kohie-Hoegeris tar I H van Wreveld, grof nir M A Loth, mo GR C Veuritik Inn E M Wesseling - van Cont nin. B, PM Weusten.

Voor begtellingen of

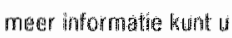
contect opnemen met: Serwicecentrum Uitgewers Teleforn 1070$) 3789890$ 19707013789783

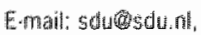

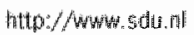
Priss incl BTW, excl. werzerdkosten. Ook verkightuar wia de boenthandel 


\section{Nieuw!}

\section{Nederlands bestuursprocesrecht in theorie en praktijk}

\section{Door prof. mr. A.Q.C. Tak}

Bestuursprocesrecht moet nensen beschermen tegen de overheid. Het is de vragg of die rechtsbescherming sinds de invoering van de Algemene wet bestuursrecht in 1994 verbeterd is.

In dit derde millennium likt yoor de rechtzoekende burget nauweliks meer sprake yan daadwerkelijke rechisbescherming tegen de overheid.

In Nederlands bestuursprocesrecht in theorie en praktijk wordt bovenstaande vraag onderzocht door éen van de pioniers op het terrein van het bestuursprocestecht: prof m. A.Q. . Tak. Het resultaat is een actieel handboek op het gelied van het bestuursprocesrecht. De arrgave is opgesplitst in twee delen ten behoeve van uw gebruiksgemak.

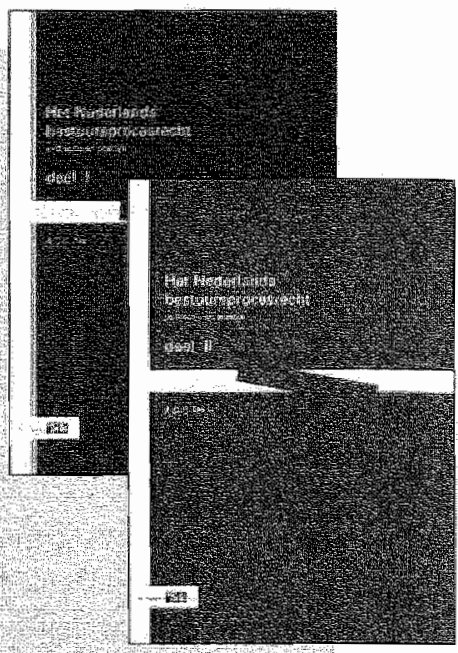

De huidige stand van zaken binnen het bestuursprocesrecht

De uitgave geeft an de hand van een prakissche, thematische indeling van het bestnursprocesrecht eet zo volledig mogelijk overzicht van de huidige stand van zaken met betrekking tot wetgeving (positief, geldend rechi) en juisprudentie. Daarnaast biedt de vitgave ook een voortitblik op binnen afzienbare tijd te verwachten wijzigingen Naast een analyse van de oorzaken van verschillende problemen reikt de auteur alternatieven an ter verbetering.

\section{De auteur}

In zinn onderzoek kon prof mr. A.Q.C.Tak gebruik maken yan zijn jarenlange en intensieve ervaring in de rechtspraak, vooral als radsheer in de Centrale Rand van Beroep en op ajph dagelijkse praktjkervaring als adviseur en vertegenwoordiger in bestuursrechtelijke procedures. Hij kreeg bekendheid ais grondlegger van de Maastrichise school en van de invullende rechtsleer, waaraan hif praktische toepassing gaf in 2 ijn indrukwekkende nonografie De onevieid in het lurgerlijk recht (1997).

Loop dit unicke handboek niet mis en bestel nu!

Voor eon goed beeld ran het huidige bestuursprocestecht is deze nitgave onumsbaar. Bestel uw exemplaar door te bellen met Servicecentrum Uitgevers, tel (070) 3789880 , of mail naar sdu(sdunl.

\section{Voor meer informatie kijkt 1 op www.sdu.nl/bestuursrecht}

Pris $\in 12,90$

ISBN $: 9054093382$

Onvarig: 1234 paginas
Voor bestedingen or ofer rofomane

Kunt r contact oprenten met:

servicecentrumulatgeners

Teloroon 1070,3789880

Tax 10707878978

Enali sdogsoum

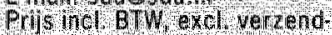

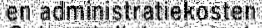

Doh werking bat wa de boekhandel 